Do Restric tions on Home Equity Extraction Contribute to Lower Mortgage Defaults?

Evidence from a Policy

Discontinuity at the Texas

Border

Anil Kumar

Federal Reserve Bank of Dallas

Research Department

Working Paper 1410 


\title{
Do Restrictions on Home Equity Extraction Contribute to Lower Mortgage Defaults? Evidence from a Policy Discontinuity at the Texas Border
}

\author{
(Forthcoming in the American Economic Journal: Economic Policy)
}

\author{
Anil Kumar* \\ Research Department \\ Federal Reserve Bank of Dallas \\ anil.kumar@dal.frb.org \\ January, 2017
}

\begin{abstract}
Texas is the only US state that limits home equity borrowing to 80 percent of home value. This paper exploits this policy discontinuity around Texas' interstate borders and uses a multidimensional regression discontinuity design framework to find that limits on home equity borrowing in Texas lowered the likelihood of mortgage default by about 1.5 percentage points for all mortgages and 4-5 percentage points for nonprime mortgages. Estimated nonprime mortgage default hazards within 25 to 100 miles on either side of the Texas border are about 20 percent smaller when crossing into Texas.
\end{abstract}

Keywords: Home Equity, Mortgage Default, Negative Equity

JEL Numbers: G21, G28, R28

\footnotetext{
*Senior Research Economist and Advisor, Research Department, Federal Reserve Bank of Dallas. The views expressed here are those of the author and do not necessarily reflect those of the Federal Reserve Bank of Dallas or the Federal Reserve System. I thank Matthew Shapiro, Raven Molloy, Kris Gerardi, Michael Kiley, You Suk Kim, Malcolm Wardlaw, John Duca, Pia Orrenius, Michael Weiss, Ed Skelton, William Larson, Alice Henriques, Andrew Foote, two anonymous referees, and participants of the 2014 Western Economic Association International Conference at Denver, CO, Federal Reserve System Committee on Regional Analysis Conference in San Antonio, TX, and the Econometric Society World Congress 2015 in Montreal, Canada for valuable comments and suggestions. I especially thank Liang Geng for help with RADAR data. I thank Christina English, Melissa LoPalo, Sarah Greer, and Stephanie Gullo for excellent research assistance. All remaining errors are my own.
} 


\section{Introduction}

The subprime mortgage crisis played a central role in the onset of the Great Recession that led to record post-war joblessness and long-term unemployment. As house prices plunged, home equity declined sharply and many homeowners went underwater on their mortgages, with their negative equity positions leaving them owing lenders more than their homes were worth. Apart from large swings in house prices and negative income shocks, excessive borrowing during the housing boom - through cash-out refinancing, closed-end home equity loans/second mortgages, and Home Equity Lines of Credit (HELOC) — was a key factor in the rising incidence of negative equity and subsequent default. Mian and Sufi (2011) found that about 40 percent of new mortgage defaults during the housing crisis were driven by active home equity extraction. Using a sample of homeowners from California, Laufer (2011) notes that even after a precipitous decline in house prices during the bust, a vast majority of homeowners who defaulted would still have had positive equity had they not engaged in aggressive home equity extraction during the boom.

Given the role of excessive borrowing in precipitating the housing crisis, economists and policymakers have focused significant attention on effective regulations to curb unaffordable mortgage debt. But evidence whether such regulations indeed work remains thin; laws limiting active home equity extraction in the US are rare. Texas is the only state that explicitly limits borrowing against home equity. ${ }^{1}$ A 1997 constitutional amendment in Texas (henceforth, also referred to as "the Texas policy") allowed home equity loans and cash-out refinancing, but restricted overall borrowing against housing equity to 80 percent or less of home value. That is, the combined loan-to-value (LTV) ratio of any pre-existing notes along with the new loan-homeequity loan, cash-out refinancing or HELOC_cannot exceed 80 percent in Texas.

Despite the policy's unique nature and potential implications, no paper has estimated its impact on overall leverage and mortgage defaults. ${ }^{2}$ This paper fills this void and makes two contributions to the previous literature on the impact of home equity extraction on mortgage default. First, to the best of my knowledge, this is the first paper to estimate the impact of Texas' home equity restrictions on mortgage default. Second, the paper exploits the policy discontinuity around the Texas border to identify the causal effect of home equity extraction on mortgage default

\footnotetext{
${ }^{1}$ Regulations to limit initial mortgage debt used to purchase a home have long existed in countries such as Austria, Poland, China, and Hong Kong.

${ }^{2}$ Laufer (2011) used a property level dataset from California and simulated the impact of Texas' home equity withdrawal restrictions on default rates, but did not directly estimate the impact of Texas' restrictions.
} 
in a Regression Discontinuity Design (RD) framework. ${ }^{3}$ The empirical strategy is to compare mortgage default probabilities or hazard rates of otherwise similar individuals or loans located in proximate counties on either side of the Texas border, controlling for smooth functions of geographical location. In doing so, the paper helps disentangle the role of active home equity extraction from other factors such as house price declines and liquidity constraints as contributors to the subprime default crisis. ${ }^{4}$

In addition to estimating the traditional one-dimensional $\mathrm{RD}$ specifications in distance to the Texas border, following Dell (2010), I employ a multidimensional RD approach and model the Texas border with neighboring states as a multidimensional discontinuity in latitude and longitude space. Latitude and longitude taken together represent a more precise measure of geographic location than simply the shortest distance to the border. Thus, the multidimensional RD can better account for unobserved location-specific factors and is subject to less finite-sample bias than a one-dimensional RD specification in distance (Imbens and Zajonc, 2011). Because a suitably flexible multidimensional RD polynomial can be high-dimensional, I use a data-driven Least Absolute Shrinkage and Selection Operator (LASSO) approach to select the number of terms (Tibshirani, 1996). A methodological contribution of the paper is to combine the multidimensional $\mathrm{RD}$ setup with the recently proposed post-double-LASSO treatment effect estimator from Belloni et al. (2014a) to estimate the causal effect of the Texas policy on mortgage default in a semiparametric partially linear framework.

Using two large databases-(1) all residential mortgages from Loan Performance and (2) nonprime mortgages from CoreLogic - the paper has three primary findings. First, Texas' home equity restrictions had a significantly negative impact on the probability of mortgage default close to the Texas border. The RD estimates for all residential mortgages indicate that the Texas policy lowered mortgage default probability by about 1.5 percentage points between 2007 and 2011—a significant effect considering that the share of individuals defaulting in the data is just about 4.3

\footnotetext{
${ }^{3}$ Also known as boundary or border discontinuity design (BDD), the method followed in the paper is a version of the widely used RD framework applied to geographic or spatial discontinuity (Bayer et al., 2007; Black, 1999; Dell, 2010; Dhar and Ross, 2012; Holmes, 1998; Pence, 2006). Because there is no time variation in the Texas policy to cap borrowing against home equity, a standard difference-in-differences framework cannot be applied.

${ }^{4}$ Since the regulation affected mortgage defaults primarily through its impact on negative home equity, the paper contributes to the reduced form evidence on the causal link between negative equity and mortgage default. Directly estimating the impact of negative home equity on mortgage default is difficult as unobserved taste for mortgage debt may be correlated with underlying preferences to walk away from one's mortgage. Also, most datasets do not have precise measures of negative equity. See Bhutta et al. (2010) for an in-depth analysis of the impact of negative equity on default.
} 
percent on average from 2007 to 2011.

Second, the policy had an even larger impact on nonprime mortgage borrowers - a group on which the Texas borrowing restrictions were likely most binding-and significantly lowered their mortgage default rate by about 4-5 percentage points. This is consistent with previous evidence that while negative equity is necessary to push homeowners over the edge and default, it shares a strong interaction with credit constraints in affecting default; those with negative equity who also face binding credit constraints are more likely to default (Campbell and Cocco, 2011; Elul et al., 2010).

Third, using loan-level data on nonprime borrowers, the paper finds evidence of a large discontinuity in mortgage default hazards at the Texas border with neighboring states. Estimated default hazards for mortgages within 25 to 100 miles of the Texas border decline by about 20 percent on the Texas side. Overall, the paper finds evidence that the Texas policy negatively affects mortgage default - $\mathrm{a}$ finding that is robust to placebo tests and to use of aggregate state/countylevel data as well as detailed loan-level data.

These findings are consistent with theory, as there are strong a priori reasons why Texas home equity restrictions may discourage default. First, the policy likely boosted home equity by capping current LTV to 80 percent and, thereby, reduced the incidence of negative equity. Economic theory predicts a strong causal link between lack of home equity and mortgage default. In option-theoretic models, negative equity (i.e., current combined LTV $\geq 100 \%$ ) is a necessary condition for triggering default; the homeowner defaults if the market value of the mortgage exceeds the home value plus any associated costs of walking away from a home e.g., moving costs (Deng et al., 2000; Vandell and Thibodeau, 1985). ${ }^{5}$ Second, homeowners who are more likely to engage in collateralized borrowing through home equity extraction to finance current consumption-those with liquidity constraints and homeowners lacking self-control or financial sophistication-are also the type of borrowers more likely to default on their mortgages. Moreover, they leave themselves with less margin for error should they encounter an economic setback. ${ }^{6}$

\footnotetext{
${ }^{5}$ See Kau and Keenan (1995) and Quercia and Stegman (1992) for a comprehensive review of the literature.

${ }^{6}$ Homeowners without liquidity constraints will have little reason to borrow against housing wealth to finance current consumption during a housing boom, as rising house prices simply mean a higher cost of using their house without any real wealth effects (Campbell and Cocco, 2007; Cooper, 2013; Sinai and Souleles, 2005). For the impact of house prices on consumption, see Duca et al. (2010) and Engelhardt (1996a). For the role of liquidity constraints see Hurst and Stafford (2004); for self-control on indebtedness see Gathergood (2012) and Laibson (1997). For the role of financial sophistication on debt or/and default see Agarwal et al. (2009), Agarwal et al. (2010), Duca and Kumar (2014), and Gerardi et al. (2010), among others.
} 
Third, by limiting the overall mortgage burden to 80 percent of home value, the Texas law affected current overall LTV as well as the total mortgage payment, thereby reducing the probability of negative equity and improving mortgage affordability (Campbell and Dietrich, 1983). And finally, previous research has found a positive link between credit quality deterioration and home equity line utilization (Agarwal et al., 2006), with the implication that the Texas policy may have discouraged homeowners from cashing out their home equity lines in anticipation of a credit shock, thus boosting home equity relative to other states and curbing eventual default.

Due to the policy's strong implications for mortgage default avoidance, the popular press and others have extensively examined why it may be an important factor that can explain how Texas navigated the housing crisis without the surge in defaults witnessed elsewhere in the nation (Katz, 2010; Norris, 2012). Such anecdotal evidence is largely based on Texas-US comparisons similar to Figure 1, which, using data from the Mortgage Bankers Association (MBA), shows that Texas had a lower incidence of subprime serious delinquencies not only compared with the nation, but also relative to the neighboring states. Moreover, the post-2007 gap widened as the mortgage crisis deepened with the onset of the Great Recession.

Nonetheless, despite strong theoretical support for the belief that the Texas policy lowered defaults, simple comparisons between Texas and other states could conflate the impact of home equity restrictions with differences in other state-level policies and characteristics. Moreover, the precise effect remains uncertain for a variety of reasons. First, by not allowing full access to housing wealth, the restriction may have tightened liquidity constraints on homeowners and, therefore, some homeowners on the margin would be more likely to default (Laufer, 2011). Second, the restriction capped combined current LTV but left initial LTV unrestricted, and therefore homebuyers may be tempted to make lower initial down payments, knowing that future borrowing against home equity will be restricted. Third, some homeowners may be driven to other more expensive sources of debt, e.g., credit card debt and payday loans. Higher credit card utilization will further tighten credit constraints on borrowers, making them more likely to default. Fourth, since negative equity is just a necessary and not a sufficient condition to default, not all households that go underwater end up defaulting on their mortgages (Foote et al., 2008). And finally, the restriction negatively affected issuance of second-lien closed-end home equity loans or HELOCs - the type of loans likely to be current longer — relative to first liens (Jagtiani and Lang, 2010). Therefore, the actual quantitative impact of Texas' home equity restrictions on mortgage 
default remains an important puzzle that this paper helps resolve. An important limitation is the paper's inability to separately identify the economic significance of the multiple channels through which the policy affected mortgage default. Nevertheless, the paper's central finding that the Texas policy inhibits mortgage default has important implications for the effectiveness of potential rules aimed at curbing excessive mortgage debt and default.

The remainder of the paper proceeds as follows. Section 2 presents a brief description of the Texas home equity restrictions. Section 3 describes the data and presents summary statistics. Section 4 presents the econometric specification and results. Finally, there is a brief conclusion.

\section{Texas Home Equity Restrictions}

Texas has historically maintained strong homestead protection laws to shield homeowners against forced sale and seizure. See Kumar and Skelton (2013) for a chronology of major events in the evolution of homestead protection laws in Texas. As part of a longstanding effort to keep creditors at bay, homeowners in Texas were severely restricted from borrowing against even their own housing wealth. Of course, homebuyers could get a mortgage loan to finance the home purchase. But once the home was purchased, home equity extraction was severely limited. Other than home purchase, the Texas constitution of 1876 permitted only two other types of liens on homesteads: (1) home improvements and (2) taxes (Graham, 2007). Since 1995, in the event of divorce, jointly owned homes could be converted to full ownership through a home equity loan to pay off the joint-owner's share of home equity. Barring these exceptions, however, almost all other forms of home equity borrowing remained out of bounds for Texas' homeowners. In particular, cash-out refinancing, a widely used form of home equity withdrawal in the rest of US, was not allowed. While refinancing, home equity could be used only to defray the cost of refinancing. Home equity loans through second mortgages or home equity lines of credit also were prohibited.

Subsequent to passage of Proposition 8 by Texas voters, House Joint Resolution 31 amended Section 50, Article XVI of the Texas constitution in 1997 and allowed home equity loans through second mortgages or cash-out refinancing. Total borrowing against home equity was, however, capped to no more than 80 percent of the home's appraised value; no such restrictions were placed on a first mortgage while purchasing the home. ${ }^{7}$ There is a widespread belief that this restriction severely limited a Texas homeowner's ability to obtain home equity-related credit

\footnotetext{
${ }^{7}$ In addition to the cap on home equity lending, Texas also has other provisions to curb predatory lending as summarized in Graham (2007).
} 
during the housing boom from 2000 to 2006 and contributed to a lower incidence of negative equity than elsewhere in the nation when the housing market collapsed and mortgage defaults spiked higher.

\section{Data and Summary Statistics}

\section{Data on mortgage default and other mortgage characteristics}

All analysis in the paper is based on two large loan-level databases of residential mortgages. First, the database of residential mortgages from McDash/Lender Processing Services (LPS) - henceforth referred to as LPS data-contains monthly information on 130 million installment-type mortgage loans covering about two-thirds of the residential mortgage market in the US from 1992 to the present. Second, I use a database of 20 million loans covering all nonagency private label securitized nonprime (subprime and Alt-A) mortgages in the US available from CoreLogic Loan Performance-henceforth referred to as ABS data- from 1992 to the present. Both of these databases are obtained from Risk Assessment, Data Analysis, and Research (RADAR) data warehouse - a centralized database of consumer credit and related securities for the Federal Reserve System. Both LPS and ABS databases contain information on monthly delinquency status through the life of the loan since origination and other key static and dynamic mortgage characteristics. They also have information on the location of property securing each mortgage: the property’s state, Zip Code, and county.

I use the entire LPS database (for all mortgages) and ABS database (for nonprime mortgages) to calculate annual county-level averages of mortgage default rate and other mortgage characteristics. A mortgage is considered in default if it is 90 or more days delinquent, in foreclosure, or Real Estate Owned (REO). Other mortgage characteristics averaged at the countylevel and used as baseline covariates are: original FICO score; share of mortgages with initial LTV greater than 80 percent; share of adjustable rate mortgages; and share of mortgages used for cashout refinancing. ${ }^{8}$ All RD results of county-level mortgage default rates are based on mortgages in Texas and the four neighboring states - Arkansas, Louisiana, New Mexico and Oklahoma from 2007 to 2011.

In addition to county-level mortgage default rate models, the paper also estimates hazard

\footnotetext{
${ }^{8}$ While the LPS data has information on just the initial LTV of each mortgage (i.e. loan amount of each mortgage in the database as a share of the purchase price of the property securing that mortgage), the ABS database on nonprime mortgages contains information on combined initial LTV (CLTV) (i.e. combined loan amount of all mortgages as a share of the purchase price of the property securing each mortgage in the database).
} 
models of mortgage default using the entire monthly delinquency history of nonprime mortgages until November 2013. Mortgage default hazard models are based on a 30\% random sample of all nonprime loans from the ABS database originating from 1998 to 2006 secured against properties in Texas and the four neighboring states.

\section{County-level house price growth}

County-level house prices are based on CoreLogic quarterly house price index data. A drawback of using CoreLogic county-level house price data is that availability varies by county size and they are not available for many smaller counties. To circumvent this problem, I impute the quarterly change in house prices for missing counties using the average quarterly house price change of non-missing adjacent counties, wherever possible, to construct a more complete countylevel house price change data. Data on distance between counties is from Collard-Wexler (2014). County-level unemployment rate, median household income and lending standards

Data on the county unemployment rate and median household income are from BLS Local Area Unemployment Statistics (LAUS) and the Census Bureau's US counties database, respectively. Following Dell'Ariccia et al. (2012), to control for differences in lending standards, I use data from the Urban Institute on county-level mortgage denial rates calculated based on HMDA data.

\section{State-level covariates}

In robustness checks I also account for cross-state differences in institutions and legal arrangements (such as foreclosure rules) using state-level data presented in Pence (2006), Ghent and Kudlyak (2011), Vicente (2013), and Choi (2012). To test the validity of the main identification assumption that homeowners do not precisely manipulate their location around the Texas border, I use state-to-state migration calculations from taxfoundation.org based on tax return data from the IRS Statistics of Income (SOI) division.

\section{Data on geographic location (latitude, longitude) and distance}

In the traditional one-dimensional RD set up, the minimum distance of the counties' centroid to the Texas interstate border serves as the forcing variable. Data on the minimum distance is from the state border dataset of Holmes (1998). Each county is assigned to different distance bands i.e., bandwidths (e.g. 10-, 25-, 50-, 75-, or 100-mile bands) around the Texas' border with neighboring states based on the minimum distance between the Texas border and the county's centroid. For loan-level mortgage default hazard models, each loan is assigned to one of these 
distance bands based on the property's county. Figure 2 shows the counties in various distance bands around the border. Census geocode data is used to get information on latitude and longitude of county centroids for constructing the multidimensional RD polynomial (Crow, 2013; Pisati, 2001).

\section{Summary statistics and simple mean comparisons}

The summary statistics in Table 1 can be used to get a first cut estimate of the discontinuity in the outcome variable-mortgage default rates_across the Texas border. The default rate for all mortgages on the Texas side of the 25-mile band around the interstate border averaged about 4 percent between 2007 to 2011 (Column 1), 1 percentage point lower than in the neighboring states (Column 2). While the difference is statistically insignificant within 25 miles, it grows to 1.4 percent and turns significant when the band is expanded to 50 miles around the Texas border. Nonprime mortgage default rates, on the other hand, averaged about 11 percent between 2007 and 2011 on the Texas side of the 25-mile band - 4 percentage points lower than neighboring states and statistically significant at the 10 percent level. The 4 percentage point difference is significant at the 5 percent level when the band is expanded to 50 miles. Other covariates are generally balanced between Texas and the bordering states within 25 miles, except for a significantly lower incidence of cash-out refinance mortgages and adjustable rate mortgages in Texas and a significantly higher unemployment rate.

The large and statistically significant difference in the share of cash-out refinance mortgages is tentative evidence in support of the view that the Texas policy successfully limited the ability of borrowers to extract home equity through cash-out refinancing. A higher unemployment rate in Texas suggests that mortgage default rates would have been even lower in Texas, had joblessness been the same as the neighboring states. Differences in means between Texas and neighboring states emerge in some covariates when the sample is expanded to 50 miles. Nevertheless, RD evidence (presented later in the paper) indicates that almost all baseline covariates, except for the unemployment rate, evolve continuously at the discontinuity threshold.

\section{Econometric Specification and Results}

\subsection{Traditional RD specification based on grouped county-level data}

Since the geographic location measures vary only at the county level, I start by estimating simple county-level regressions of the mortgage default rate on the RD polynomial and other baseline covariates grouped to county and year level from 2007-2011. All county-level estimates 
are weighted by number of mortgages and standard errors clustered at the county level to account for potential serial correlation. The baseline RD specification can be written as:

PctMortDefault $_{c s t}=\beta_{0}+\beta_{1}$ Texas $_{s}+\delta g\left(\right.$ MinDist $\left._{c s}\right)+\gamma Z_{c s t}+d_{t}+u_{c s t}$

In equation (1), $c$ denotes county, $s$ indexes state and $t$ denotes year. PctMortDefault cst $_{\text {is }}$ county-level share of mortgages that are 90 days or more delinquent, in foreclosure, or REO. The treatment variable Texas $_{s}$ is a dummy for mortgages located in Texas. $g\left(\right.$ MinDist $\left._{c s}\right)$ is the RD polynomial in minimum distance of the county's centroid to the Texas border (normalized to zero at the border). $Z_{c s t}$ is a set of other exogenous county-level covariates correlated with the mortgage default rate. $d_{t}$ is a time effect. The error term $u_{c s t}$ represents unobserved county-level taste or preference for mortgage default.

For a consistent estimate of the policy impact, $\beta_{1}$, the key identifying assumption is that, while the treatment variable Texas $_{s}$ is a discontinuous function of MinDist unobserved factors vary continuously with location and $E\left(u_{c s t} \mid \operatorname{MinDist}_{c s}, Z_{c s t}\right)=0$. Intuitively, the necessary condition for identification is that homeowners in counties on the Texas side of the border are not able to precisely manipulate their location and move across the border simply to self-select out of the treatment group affected by Texas home equity restrictions (Lee and Lemieux, 2010). Before presenting informal tests of the key identification assumption, I next examine the baseline evidence of discontinuity in nonprime mortgage default rate.

\section{Baseline RD estimates}

Table 2 reports baseline RD estimates of the Texas policy by regressing county-level mortgage default rates on a linear RD polynomial in distance to the Texas border. The coefficient on the Texas dummy measures the extent of discontinuity in the mortgage default rate at the Texas border and can be interpreted as the causal effect of the policy difference on the Texas side of the border. To ensure that default outcomes of individuals outside Texas are valid counterfactuals for those on the Texas side, the sample is restricted to sufficiently narrow bands of 25 to 100 miles on both sides of the Texas border.

Unshaded (odd numbered) columns of Table 2 do not include any covariates other than year effects. The shaded (even numbered) columns report estimates from a parsimonious model consisting of three key predictors of mortgage default-the county unemployment rate, 1-year lagged log house price change (Lagged $\Delta H P I)$, and county-level initial FICO score. Panel A reports county-level baseline RD estimates for all mortgages (from the LPS database) and Panel 
B for nonprime mortgages (from the ABS database). Table 2 shows that default rates on all mortgages are about 2-3 percentage points lower within 25 to 100 miles on the Texas side of the border. The discontinuity in nonprime default rates is significantly larger than that for all mortgages-about 3-8 percentage points lower on the Texas side.

The extent of discontinuity generally increases in models with covariates. This is not surprising because mortgage default rates in Texas are expected to be even lower once we account for the state's higher unemployment rate. Overall, the baseline estimates in Table 2 indicate statistically significant evidence of discontinuity as one crosses into the Texas side of the border and the RD estimates are particularly large for nonprime mortgages.

\section{Graphical RD evidence}

Figure 3 presents graphical evidence of discontinuity in the nonprime default rate by plotting the means for each discrete value of the running variable, distance from the Texas border, together with fitted lines on both sides of the border. The sample is restricted to counties within narrow bands of 25 to 100 miles on both sides of the Texas border. The difference in the intercept of the fitted lines represents the RD estimate of the Texas policy's impact on default rates. Based just on raw data without any adjustment for differences in baseline covariates, the scatterplot appears noisy but the cloud of scatter points for each distance band on the Texas side is lower than that across the border.

To reduce noise, Figure 4 plots binned conditional means for 10-mile wide binsconditional on the unemployment rate, lagged house price change, and initial FICO score- for 50to 150-mile bands around the Texas border. Linear fitted lines are based on regression of countylevel mortgage default rate (adjusted for the baseline covariates) on a linear polynomial in distance. ${ }^{9}$ Large differences in intercepts of the linear fitted lines in Figures 4 present strong visual evidence of discontinuity in default, similar in magnitude to numerical baseline estimates for nonprime default rates in Table 2. Figures A1-A3 in Appendix A show that the visual evidence of discontinuity is remarkably robust to plots for 5-mile bin width and to quadratic fits rather than the linear fits used in Figures 4.

As a further robustness check, rather than form bins of pre-specified width of 5 or 10 miles,

\footnotetext{
${ }^{9}$ To plot a fitted line conditional on other covariates, as suggested in Lee and Lemieux (2010), county-level mortgage default rates are first residualized by subtracting the prediction from a regression on other baseline covariates. Then the residualized version is regressed on the linear polynomial on distance to get the fitted line.
} 
Figure A4 shows visual evidence of discontinuity for 50- to 200-mile bands around the Texas interstate border by selecting bins using the IMSE-optimal evenly spaced method in Calonico et al. (2014a, 2015). The extent of discontinuity in binned scatterplots as well as quadratic fits appears similar to those in Figures A1-A3. Although there is significant evidence of discontinuity in the county-level nonprime mortgage default rate, identification relies on other unobserved factors evolving continuously with respect to the minimum distance to the Texas border. I next present informal tests of the key identification assumptions.

\section{Continuity in other baseline covariates}

The summary statistics presented in Table 1 show some noticeable differences in key covariates between Texas and neighboring states. Differences in variables such as the share of cash-out refinancing and incidence of underwater mortgages are not surprising because the Texas policy potentially lowered mortgage default rates through its impact on these variables. However, lack of continuity in other covariates is a potential concern deserving further investigation. I start by exploring covariate continuity at a 10-mile bandwidth. Panel A of Figure 5 shows that, conditional on the running variable, all housing market characteristics evolve continuously at 10 miles, with just two covariates showing discontinuity - the unemployment rate is higher and median household income is somewhat lower on the Texas side. Both will, however, downwardly bias the size of the law's estimated effect. The continuity in mortgage denial rates suggests that lending standards in Texas were no more conservative than neighboring states. ${ }^{10}$

While such isolated violations of continuity in individual covariates also occur at other bandwidths, covariate-by-covariate continuity appears to largely hold at data-driven Mean Squared error (MSE)-Optimal bandwidth choices of 78 miles with covariates and 117 miles without covariates. Table A5 in Appendix A reports robust RD estimates along with data-driven MSEOptimal bandwidth choices for specifications without covariates and covariate-adjusted specifications using the bandwidth selection procedure in Calonico et al. (2014a, 2014b). Estimated discontinuities in covariates for the MSE-Optimal bandwidths are reported in Table A8 in Appendix A. Panel B of Figure 5, plotting discontinuities for the more conservative MSEoptimal 78-mile bandwidth, shows that almost all housing market variables evolve continuously

\footnotetext{
${ }^{10}$ Figure A5 in Appendix A provides a closer look at potential discontinuity in four different measures of mortgage denial rate based on income categories. The overlapping confidence intervals around the linear fits on either side of the discontinuity threshold in all four panels of Figure A5 suggest that there is no evidence of discontinuity in measures of lending standards.
} 
at the RD threshold and the unemployment rate and median household income discontinuities are statistically insignificant. A modestly smaller share of ARMs in Texas is the only exception-the likely result of a Texas policy limiting active mortgage withdrawals through HELOCs, which are mostly variable rate.

Although graphical inspection of discontinuities in individual covariates is useful, recent papers have cautioned against sole reliance on tests of covariate-by-covariate equality of means in RD settings, as some could by random chance appear significant. Canay and Kamat (2016) noted that testing several individual hypothesis provides useful insights but can lead to "spurious rejections”-long a known problem of multiple-testing. This concern was also highlighted in recent work on Regression Kink Designs (RKD) methodology by Card, Lee, Pei, and Weber (2012), who proposed a more holistic approach to assessing covariate balance. They suggested testing for kinks in a "covariate index"-the predicted outcome from a simple regression of the outcome variable on the set of covariates.

Extending this novel approach to test for discontinuities in the "covariate index" constructed from an expanded set of covariates, Panels A and B of Figure 6 show binned scatterplots and linear fits for the 10-mile bandwidth (Panel A) and the MSE-Optimal 78-mile bandwidth (Panel B). ${ }^{11}$ The discontinuities in the "covariate index" are small and insignificant while those in the outcome variable-the mortgage default rate-are relatively large and significant. Panel C of Figure 6 shows the index evolving continuously at all bandwidths, from 10 miles to 100 miles (at 5 mile increments), with large and significant discontinuities in the mortgage default rate at most bandwidths. Implied P-values from placebo tests presented in Figure B3 in Appendix B rule out evidence of discontinuity in the "covariate index" while confirming strong evidence of discontinuity in the mortgage default rate. ${ }^{12}$ These results taken together suggest that covariate balance holds more broadly.

\subsection{County-level multidimensional RD framework}

While traditional one-dimensional RD specifications provide compelling evidence of the Texas policy's effect on mortgage default, recent research has proposed a multidimensional

\footnotetext{
11 The set of covariates used to construct the covariate index includes: initial FICO, lagged house price change, mortgage denial rate, share of borrowers with initial CLTV 80 percent or higher, share of ARMs, unemployment rate, and median household income.

${ }^{12}$ Using IRS data on state-to-state migration of tax returns, Table A2 in Appendix A presents tentative evidence that borrowers did not manipulate their location in response to the 1997 amendment that eased access to home equity.
} 
approach to implement boundary RD design methods of the type used in this paper (Dell, 2010; Imbens and Zajonc, 2011). In this case, the discontinuity threshold is a multidimensional discontinuity in latitude and longitude space. Using more precise measures of location as running variables, this multidimensional RD approach can better account for location-specific factors and is subject to less finite-sample bias than a one-dimensional method that uses distance alone as the running variable. ${ }^{13}$ In this framework the multidimensional RD polynomial consists of smooth functions of the vector of running variables-latitude $(X)$ and longitude $(Y)$, denoted $\left(\sum_{p=0}^{P} \sum_{q=0}^{Q} \delta_{p q} X_{c s}^{p} Y_{c s}^{q}\right) .{ }^{14}$ Because the multidimensional RD polynomial varies only with county, I estimate the following specification based on county-year level data, weighting estimates by number of mortgages and clustering standard errors at the county level to account for serial correlation:

PctMortDefault $_{c s t}=\beta_{0}+\beta_{1}$ Texas $_{s}+\sum_{p=0}^{P} \sum_{q=0}^{Q} \delta_{p q} X_{c s}^{p} Y_{c s}^{q}+\gamma Z_{c s t}+d_{t}+u_{c s t}$

In estimating equation (2), I go beyond the baseline specification in (1) and include a richer set of covariates in $Z_{c s t}$, with their choice guided by previous research that found negative equity, mortgage affordability, and liquidity constraints are the key determinants of mortgage default (Campbell and Cocco, 2011; Elul et al., 2010). In addition to the three key covariates - the county unemployment rate, 1-year lagged annual house price change (Lagged $\Delta H P I$ ), and county-level initial FICO score- included for baseline estimates in Table 2, I account for whether the initial LTV (CLTV in ABS data) was 80 percent or higher, county-level log median household income, share of adjustable rate mortgages, share of cash-out refinance mortgages, and average countylevel mortgage denial rate between 2000 and 2006. ${ }^{15}$ Finally, I also account for state border specific characteristics $\left(\alpha_{b}\right)$ by including dummies for three of the four state border segments: TXAR, TX-LA, TX-NM, TX-OK.

\footnotetext{
${ }^{13}$ For example, consider a Texas treatment county located within 10 miles of the Texas-New Mexico border along with two other counties, one each in New Mexico and in Arkansas, also within 10 miles of the border, as potential counterfactuals. Situated directly across the border, the New Mexico county clearly is a better counterfactual than the distant Arkansas county. In terms of the one-dimensional shortest distance to the border, however, both are considered equidistant from the treatment county. On the other hand, the two-dimensional measure of location would aptly treat the adjacent New Mexico county as the better counterfactual for the treatment county on the Texas-New Mexico border, as the latitude and longitude values are more similar than those for the Arkansas county.

${ }^{14} P=Q=3$ with $p+q \leq 3$ in $\sum_{p=0}^{P} \sum_{q=0}^{Q} \delta_{p q} X_{c S}^{p} Y_{c S}^{q}$ dropping all redundant terms would yield a cubic polynomial. ${ }^{15}$ I do not control for other unorthodox features of mortgages-e.g., negative amortization, interest-only mortgages, balloon mortgages etc. - as there may not be enough variation in a close band around the border. Moreover, Mayer et al. (2009) found that they did not significantly affect default rates.
} 


\section{LASSO selection of RD polynomial terms}

The previous literature typically has used linear, quadratic, or cubic specification for the multidimensional RD polynomial $\left(\sum_{p=0}^{P} \sum_{q=0}^{Q} \delta_{p q} X_{c s}^{p} Y_{c S}^{q}\right)$. The tradeoff involved in selecting a low vs. a high order RD polynomial is well-known. A high order polynomial can have a large number of terms and can easily result in overfitting and imprecise estimates, particularly if estimation is restricted to data close to the discontinuity threshold, while a low order polynomial can lead to biased estimates. To dispense with arbitrary selection of the number of terms in the multidimensional RD polynomial, I use the recently proposed post-double-LASSO treatment effect estimator from Belloni et al. (2014a). A number of recent papers have shown that LASSO is an appealing and computationally efficient method to estimate parameters in high-dimensional models Belloni et al. (2012, 2014b). LASSO minimizes least-square errors subject to a constraint on the sum of absolute value of coefficients. The penalty level $(\lambda)$ is a key parameter that determines the parsimony or the number of nonzero coefficients in the model. A high $\lambda$ selects parsimonious models by setting weakly correlated terms to zero, while a small $\lambda$ yields models with a large number of terms; $\lambda=0$ yields the OLS specification. As described in Appendix C, I select $\lambda$ based on practical guidelines and procedures in Belloni et al. (2014a) and explore the sensitivity of estimates to different choices of $\lambda$.

\section{Results using LPS database on all mortgages}

Table 3 reports multidimensional RD estimates of the effect of the Texas policy on the mortgage default rate based on the model with an extensive set of covariates, presented in equation (2). Estimates are based on county-year level data on all residential mortgages. The top three panels present estimates from linear, quadratic, and cubic polynomials in latitude and longitude, respectively. Overall, Table 3 suggests that the Texas policy is associated with significantly lower mortgage default rates of about 1 to 1.5 percentage points-plausibly by curbing home equity extraction and limiting negative equity. The effect is economically significant as the average default rate for all mortgages in Texas between 2007 and 2011 is just about 4 percent. The bottom panel shows estimates from multidimensional RD applied in combination with the post-doubleLASSO treatment effect estimator from Belloni et al. (2014a) (equation (5) in Appendix C). Using LASSO to choose terms from a fourth order multidimensional RD polynomial yields a parsimonious model with 1-3 terms for various distance bands around the Texas interstate border. LASSO results are qualitatively similar to other estimates in Table 3 and essentially show that 
results are robust to using a model that is partially linear in spirit.

\section{Results for nonprime mortgages using ABS database}

Using all residential mortgages could understate the true impact of the Texas policy on mortgage default if some homeowners with mortgages in Texas were either not or only partially affected by the policy. ${ }^{16}$ Nonprime borrowers are more intensely affected by the Texas policy as they are likely to be closer to the 80 percent combined LTV threshold. Moreover, scatterplots and fitted lines in Figure A6 (Appendix A) suggest that the policy appears to have successfully inhibited cash-out refinancing - a primary channel of home equity extraction-among nonprime borrowers in Texas. Simple difference in means presented in Table 1 and simple linear RD regression estimates in Table A3 show that the share of mortgages more than 20 percent underwater is generally lower in Texas, although some estimates are imprecise as the data are available only for a limited number of counties. ${ }^{17}$

Table 4 repeats the exercise in Table 3 using data on nonprime mortgages and provides cleaner estimates of the impact of policy discontinuity across the Texas border. The estimated Texas policy discontinuity is statistically significant and remarkably robust across different polynomial specifications and suggests that the Texas policy lowered nonprime mortgage defaults by 4-5 percentage points. The impact is about four times as large as the estimated impact using LPS data on all residential mortgages in Table 3. The effect is economically significant as the average nonprime default rate in Texas between 2007 and 2011 is just about 12 percent.

\section{Robustness}

Due to space constraints, further robustness checks of the county-level estimates are presented in Appendix A. I start with checking robustness with respect to state-level differences in legal and institutional arrangements. While all five states in the estimation sample are recourse states and allow deficiency judgment, some differences exist. For example, Louisiana, Oklahoma, and New Mexico require a judicial foreclosure process, while Texas and Arkansas do not. New

\footnotetext{
${ }^{16}$ For example, the home equity restriction may not be fully binding on homeowners who already had sufficient equity in their homes. Mian and Sufi (2011) found that homeowners in the bottom quartile of the credit score distribution did much of the borrowing against housing wealth during the house price boom, while those in the top quartile were far less likely to extract home equity. Pennington-Cross and Chomsisengphet (2007) found that roughly half of refinancing by subprime borrowers was for cash-out—almost twice as likely as prime borrowers—and 85 percent of subprime refinances with fixed rate mortgages engaged in cash-out refinancing from 1996-2003.

${ }^{17}$ Data on negative equity is from the CoreLogic TrueLTV database available from the RADAR data warehouse. I must acknowledge that negative equity calculations in this database are based on several model assumptions that limit its reliability. The data have gaps and are also not available for all counties, just the larger counties.
} 
Mexico is the only state in the sample that provides the right of redemption. Table A4 shows that estimated effects are robust to controls for state-specific policy differences. ${ }^{18}$ Table A5 examines sensitivity to nonparametric methods in Calonico et al. (2014b). Table A6 shows that estimates are robust to restricting the estimation sample to contiguous border counties (Dube et al., 2010). Additionally, using the interstate borders of the remaining 47 contiguous states as placebo borders, placebo tests presented in Appendix B bolster the conclusion that the Texas policy indeed significantly lowered nonprime mortgage defaults. As an alternative placebo test suggested in Nichols (2007), Figure B3 in Appendix B plots the distribution of the estimated RD coefficients at 100 randomly drawn placebo cutoffs within the estimation sample and plots implied p-values based on a comparison with the estimated discontinuity at the actual RD cutoff.

Finally, Table A9 in Appendix A compares the covariate-adjusted multidimensional RD estimates reported in Tables 3 and 4 with those without covariates and reflects a pattern similar to Table 2; inclusion of covariates generally moves the RD estimate further below zero, although estimates appear more stable than those in Table 2. Oster (2017) uses the coefficient and R-squared movements between specifications with and without additional covariates to derive formulas for informative bounds on an identified set for the treatment effect. Calculations using those formulas provide two useful insights. First, because inclusion of covariates generally moves the estimates further below zero, almost all the results reported in Tables 3 and 4 represent the lower bounds of the identified set. Indeed, the identified set never includes zero. Secondly, the bounds of the identified set, reported in Table A9, suggest that the true effect of the Texas policy on mortgage default could potentially be larger in magnitude than those estimated in Tables 3 and 4.

\section{Results by origination year}

The results presented in Table 4 do not distinguish between mortgage vintages. Recent research has documented exceptionally poor performance of 2006 and 2007 vintage loans, suggesting that underwriting criteria deteriorated significantly for mortgages that originated in the "go-go" years near the peak of the housing boom. ${ }^{19}$ If so, then part of the estimated impact in Table

\footnotetext{
${ }^{18}$ Judicial foreclosure process is apparently the most pervasive difference between Texas and the bordering states. Therefore, the finding is consistent with Vicente (2013), who also finds no impact of judicial process on delinquency. ${ }^{19}$ Demyanyk and Van Hemert (2011) found that loan quality deteriorated progressively between 2001 and 2007 as combined LTV increased. Lax lending standards contributed to proliferation of increasingly risky high-LTV borrowers. Bayer et. al. (2013) found that the black-white differential in mortgage default spiked as the housing market peaked in 2006 and minority homeowners with high debt-to-income ratios were particularly at risk of default on mortgages that originated between 2004 and 2006.
} 
4 could simply be due to relatively more lax lending standards in neighboring states driving up nonprime default rates relative to Texas.

Focusing on counties within 50 miles of the Texas border, Figure 7 shows that initial CLTV and debt-to-income (DTI) climbed, while the share of cash-out refinances declined both in Texas and bordering states for vintages leading up to the housing boom. The higher DTI ratio in Texas partly assuages the concern that lenders were more conservative than those just across the border. Figure 7 also reinforces the finding in Figure A6 and shows that Texas' mortgages remained significantly less prone to being used for cash-out across all vintages. Importantly, the Texasbordering state differential in key mortgage characteristics remained small and largely stable as the housing market gained steam.

To shed more light on the important drivers of the Texas-bordering state differential in nonprime default rates, Figure 8 plots the estimated coefficient on the Texas dummy for three different specifications and shows that the coefficient remained negative for all vintages except the 2001 vintage. Adding measures of lending standards (DTI ratio and mortgage denial rate) to the baseline specification raises the policy's estimated impact. Adding the share of cash-out refinancing mortgages to the regression significantly weakens the estimated effect, confirming the intuition that much of the policy's impact operated through its role in restraining cash-out mortgages in Texas relative to other states.

Figure 8 also shows that the policy's estimated impact is significantly stronger for vintages 2002 and after, and there are no spikes in 2006 or 2007. A weaker estimated effect for vintages leading up to the housing boom further alleviates the concern that lending standards became more lax just across the border from Texas as the housing market peaked. Results on county-level mortgage defaults presented so far do not distinguish between the incidence of default and the duration before mortgages default. Using loan-level data I next examine whether the Texas policy lowered mortgage default hazards.

\subsection{Duration models using loan-level ABS data on nonprime mortgages Nonparametric survival probabilities}

Figure 9 compares simple nonparametric Kaplan-Meier survival probabilities of Texas' nonprime mortgages with those from bordering states within 50 miles of the Texas border. The top left panel shows that survival probabilities, overall, were uniformly higher among nonprime mortgages in Texas at all durations. The remaining three panels show that survival rates in Texas 
are higher than bordering states for all three vintages shown in Figure 9, but the difference is larger for the 1998-2000 and 2001-03 vintages. ${ }^{20}$ Going beyond simple comparisons in Figure 9, I now examine the policy's impact on mortgage default hazards using multidimensional RD specifications.

\section{Cox proportional hazard model with $R D$ using loan-level data on nonprime mortgages}

The following hazard model for mortgage default is estimated using Cox Proportional Hazard framework of the form:

$$
\psi\left(t \mid X_{i c s t}, \beta\right)=\psi_{0}(\mathrm{t}) \exp \left\{X_{i c s t} \beta\right\}
$$

In equation (3), $i$ indexes loans, $\psi\left(t \mid X_{i c s t}, \beta\right)$ is the hazard rate of mortgage default in month $t$ given that the borrower has not defaulted until month $t-1, \psi_{0}(\mathrm{t})$ is the baseline hazard function that depends on duration $t$. The term $\exp \left(X_{\text {icst }} \beta\right)$ captures the impact of covariates on the mortgage default hazard. Analogous to equation (2), the specification for Cox proportional hazard model takes the following form in a multidimensional RD framework: ${ }^{21}$

$$
\psi\left(t \mid X_{i c s t}, \beta\right)=\psi_{0} \exp \left\{\beta_{0}+\beta_{1} \text { Texas }_{s}+\sum_{p=0}^{P} \sum_{q=0}^{Q} \delta_{p q} X_{c s}^{p} Y_{c s}^{q}+\gamma Z_{i c s t}+d_{t}+u_{i c s t}\right\}
$$

The vector $Z$ includes key county-level covariates: unemployment rate, 1-quarter Lagged $\Delta H P I$, log median household income, and pre-2007 mortgage denial rate; and loan-level characteristics: initial FICO score, whether the initial CLTV was 80 percent or higher, adjustable-rate mortgage, and whether the loan purpose was cash-out refinance. Additionally, I control for year and month effects, and origination year effects. Because $\sum_{p=0}^{P} \sum_{q=0}^{Q} \delta_{p q} X_{c S}^{p} Y_{c s}^{q}$ and some baseline covariates vary only at the county level, the standard errors in estimation of (4) are clustered at the county level.

Table 5 reports Cox proportional hazard estimates in a form similar to county-level RD estimates presented in Table 4 and shows that mortgage default hazards are significantly smaller on the Texas side of the border when the sample is restricted to narrow bands around the border.

\footnotetext{
${ }^{20}$ The larger difference in survival rate between Texas and bordering states for 2001-03 vintages relative to 2004-06 is broadly consistent with the pattern in cash-out refinancing activity. The Texas policy likely kept at bay a strong surge in cash-out refinance mortgages from 2001 to 2003, a trend that ebbed somewhat between 2004 and 2006 (Demyanyk and Van Hemert, 2011; Khandani et al., 2013).

${ }^{21}$ See Card et al. (2007) for a similar specification using standard RD approach. ${ }^{22}$ For hazard model estimation, loans were followed up from origination to either default or non-default until the end of the sample period in 12/2011 for a maximum period of 153 months. All non-defaulting loans were treated as right-censored. The survival data is single spell with right-censoring. RD polynomial terms used in the LASSO specification of the Cox model reported in Panel D of Table 5 are chosen using simple linear regressions.
} 
The coefficient on the Texas treatment dummy can be interpreted as percent difference in nonprime mortgage default rates between Texas and neighboring states. Comparing mortgages within 25 miles on either side of the Texas border, column (1) shows that the Texas policy lowered nonprime mortgage defaults by 10-20 percent, but results are imprecise. Precision improves with wider distance bands that use more data and estimates turn significant. Overall, Table 5 indicates a strong negative effect of the Texas policy on nonprime mortgage default hazards in a close neighborhood on both sides of the border and the estimated impact ranges from 13 to 28 percent with a midpoint of about 20 percent. $^{22}$

\section{Conclusion}

It is now widely believed that aggressive home equity extraction by borrowers with inadequate ability to service unaffordable debt helped precipitate the subprime mortgage crisis. Regulations to curb excessive mortgage debt have long existed in other countries but Texas is the only state in the US that limits home equity borrowing to 80 percent of home value. Anecdotal reports have suggested that Texas' limits shielded homeowners from the worst of the subprime mortgage crisis. However, there remained no formal investigation of the regulation's role in curbing mortgage default in Texas. This paper is the first to estimate the impact of Texas home equity restrictions on mortgage default using loan-level data from two different sources. The paper exploits the policy discontinuity around Texas' interstate borders, induced by Texas' home equity restrictions, to identify the causal effect of home equity extraction on mortgage default in a spatial RD framework.

In addition to the standard one-dimensional regression discontinuity design (RD) setup, I employ a multidimensional RD approach from Dell (2010) and model the Texas border with neighboring states as a multidimensional discontinuity in latitude and longitude space. Because a suitably flexible multidimensional RD polynomial can be high-dimensional, I combine this method with recently proposed post-double-LASSO treatment effect estimator from Belloni et al. (2014a) to estimate the impact of Texas home equity restrictions on mortgage default.

The paper finds that the Texas home equity restrictions lowered the likelihood of default for all residential mortgages by about 1 percentage point between 2007 and 2011. This effect is

\footnotetext{
${ }^{22}$ For hazard model estimation, loans were followed up from origination to either default or non-default until the end of the sample period in 12/2011 for a maximum period of 153 months. All non-defaulting loans were treated as rightcensored. The survival data is single spell with right-censoring. RD polynomial terms used in the LASSO specification of the Cox model reported in Panel D of Table 5 are chosen using simple linear regressions.
} 
economically significant, considering that the share of individuals defaulting in the data is just about 4.3 percent on average from 2007 to 2011. The paper also finds that the Texas policy of restricting home equity extraction had a much larger impact on nonprime mortgage default rates of about 4-5 percentage points, also a sizeable effect relative to the average 13 percent nonprime default rate between 2007 and 2011. Moreover, bounds on the policy’s impact using formulas in Oster (2017) suggest that the true effect could in fact be larger and, therefore, estimates should be viewed as lower bounds. Estimated default hazards for mortgages within 25 to 100 miles of Texas' borders decline by about 20 percent as one crosses into the Texas side of the border. Overall, the paper finds evidence that Texas' home equity restrictions negatively affected mortgage defaulta finding that is robust to use of aggregate state-level data as well as detailed loan-level data.

These findings are consistent with simulation evidence in Laufer (2011) - the only other paper to have considered the effect of a Texas-style policy-which found that home equity borrowing restrictions lowered default by 28 percent and were welfare-enhancing. My findings have important policy implications for the effectiveness of potential future regulations to curb excessive mortgage debt. The findings suggest that policies to curb excessive home equity extraction by capping LTV can, indeed, lower eventual default. Such policies can be effective substitutes for costly loan modification policies followed previously (Foote et al., 2008). My findings also suggest that such policies may be particularly effective in curbing mortgage defaults among nonprime borrowers. Nevertheless, this paper is unable to shed light on the effectiveness of regulations to limit debt-to-income ratios that address incidence of mortgage defaults due to liquidity constraints (Bajari et al., 2008; Campbell and Cocco, 2011). Given the strong roles of negative equity, liquidity constraints, and their interaction in precipitating default, it may well be optimal to pursue a combination of policies to prevent future turmoil.

Although, overall, my findings point to potential benefits from such regulations, attendant costs of such policies and some caveats must be kept in mind. While mandatory caps on home equity borrowing helped Texas curb mortgage defaults, the limits also could hurt long-term economic growth by impeding consumer spending during a housing boom, preventing homeowners from optimally utilizing their home equity and tightening liquidity constraints (Abdallah and Lastrapes, 2012; Engelhardt, 1996b). Second, as Laufer (2011) noted, such policies reduce the value of housing collateral and could contribute to smaller house price gains in Texas, relative to other states, further eroding its benefits. The Texas restrictions also could unintendedly 
push credit-constrained individuals to more expensive credit card debt or even more exorbitant payday loans. A more comprehensive analysis of the policy’s likely costs is left to future research. 


\section{References}

Abdallah, Chadi S., and William D. Lastrapes. 2012. "Home Equity Lending and Retail Spending: Evidence from a Natural Experiment in Texas." American Economic Journal: Macroeconomics 4 (4): 94-125.

Agarwal, Sumit, Brent W. Ambrose, and Chunlin Liu. 2006. "Credit Lines and Credit Utilization.” Journal of Money, Credit and Banking, 1-22.

Agarwal, Sumit, Gene Amromin, Itzhak Ben-David, Souphala Chomsisengphet, and Douglas D. Evanoff. 2010. "Learning to Cope: Voluntary Financial Education and Loan Performance during a Housing Crisis.” The American Economic Review, 495-500.

Agarwal, Sumit, John Driscoll, Xavier Gabaix, and David Laibson. 2009. "The Age of Reason: Financial Decisions over the Life-Cycle and Implications for Regulation.” Brookings Papers on Economic Activity 2009 (2): 51-117.

Bajari, Patrick, Chenghuan Sean Chu, and Minjung Park. 2008. “An Empirical Model of Subprime Mortgage Default from 2000 to 2007.” National Bureau of Economic Research. http://www.nber.org/papers/w14625.

Bayer, Patrick, Fernando Ferreira, and Robert McMillan. 2007. "A Unified Framework for Measuring Preferences for Schools and Neighborhoods.” Journal of Political Economy 115 (4): 588-638. doi:10.1086/509550.

Bayer, Patrick, Fernando Ferreira, and Stephen L. Ross. 2013. “The Vulnerability of Minority Homeowners in the Housing Boom and Bust.” National Bureau of Economic Research. http://www.nber.org/papers/w19020.

Belloni, Alexandre, Daniel Chen, Victor Chernozhukov, and Christian Hansen. 2012. "Sparse Models and Methods for Optimal Instruments with an Application to Eminent Domain.” Econometrica 80 (6): 2369-2429.

Belloni, Alexandre, Victor Chernozhukov, and Christian Hansen. 2014a. "High-Dimensional Methods and Inference on Structural and Treatment Effects.” The Journal of Economic Perspectives 28 (2): 29-50.

- 2014b. "Inference on Treatment Effects after Selection among High-Dimensional Controls." The Review of Economic Studies 81 (2): 608-650.

Bhutta, Neil, Jane Dokko, and Hui Shan. 2010. The Depth of Negative Equity and Mortgage Default Decisions. Division of Research \& Statistics and Monetary Affairs, Federal Reserve Board.

Black, Sandra E. 1999. “Do Better Schools Matter? Parental Valuation of Elementary Education.” Quarterly Journal of Economics, 577-599.

Calonico, Sebastian, Matias D. Cattaneo, and Rocio Titiunik. 2014a. "Robust Nonparametric Confidence Intervals for Regression-Discontinuity Designs.” Econometrica 82 (6): 22952326.

2014b. "Robust Data-Driven Inference in the Regression-Discontinuity Design.” Stata Journal 14 (4): 909-946.

—. 2015. “Optimal Data-Driven Regression Discontinuity Plots.” Journal of the American Statistical Association, 110(512), pp.1753-1769.

Calonico, Sebastian, Matias D. Cattaneo, Max H. Farrell, and Roc1o Titiunik. 2017. "Rdrobust: Software for Regression Discontinuity Designs.” Stata Journal, forthcoming.

Cameron, A. Colin, Jonah B. Gelbach, and Douglas L. Miller. 2011. "Robust Inference with Multiway Clustering.” Journal of Business \& Economic Statistics 29 (2). 
Cameron, A. Colin, and Douglas L. Miller. 2013. “A Practitioner’s Guide to Cluster-Robust Inference.” Forthcoming in Journal of Human Resources.

Campbell, John Y., and Joao F. Cocco. 2007. "How Do House Prices Affect Consumption? Evidence from Micro Data.” Journal of Monetary Economics 54 (3): 591-621.

Campbell, John Y., and João F. Cocco. 2011. “A Model of Mortgage Default.” National Bureau of Economic Research. http://www.nber.org/papers/w17516.

Campbell, Tim S., and J. Kimball Dietrich. 1983. “The Determinants of Default on Insured Conventional Residential Mortgage Loans.” The Journal of Finance 38 (5): 1569-81.

Canay, Ivan A., Vishal Kamat. 2016. “Approximate Permutation Tests and Induced Order Statistics in the Regression Discontinuity Design.” Centre for Microdata Methods and Practice, Institute for Fiscal Studies.

Card, David, Raj Chetty, and Andrea Weber. 2007. "Cash-on-Hand and Competing Models of Intertemporal Behavior: New Evidence from the Labor Market.” Quarterly Journal of Economics 122 (4): 1511-60.

Card, David, David Lee, Zhuan Pei, and Andrea Weber. 2012. "Nonlinear Policy Rules and the Identification and Estimation of Causal Effects in a Generalized Regression Kink Design.” National Bureau of Economic Research. http://www.nber.org/papers/w18564.

Chetty, Raj, Adam Looney, and Kory Kroft. 2009. "Salience and Taxation: Theory and Evidence." American Economic Review 99 (4): 1145-77.

Choi, Hyun Soo. 2012. "The Impact of the Anti-Predatory Lending Laws on Mortgage Volume.” http://ink.library.smu.edu.sg/lkcsb_research/3280/.

Collard-Wexler, Allan. $2014 . \quad$ "Adjacent County Data.” http://pages.stern.nyu.edu/ acollard/Data.html.

Cooper, Daniel. 2013. "House Price Fluctuations: The Role of Housing Wealth as Borrowing Collateral.” Review of Economics and Statistics 95 (4): 1183-1197.

Crow, Kevin. 2013. SHP2DTA: Stata Module to Converts Shape Boundary Files to Stata Datasets. Statistical Software Components. Boston College Department of Economics.

Dell, Melissa. 2010. “The Persistent Effects of Peru’s Mining Mita.” Econometrica 78 (6): 18631903.

Dell'Ariccia, Giovanni, Deniz Igan, and Luc Laeven. 2012. "Credit Booms and Lending Standards: Evidence from the Subprime Mortgage Market.” Journal of Money, Credit and Banking 44 (2-3): 367-384.

Demyanyk, Yuliya, and Otto Van Hemert. 2011. “Understanding the Subprime Mortgage Crisis.” Review of Financial Studies 24 (6): 1848-1880.

Deng, Yongheng, John M. Quigley, and Robert Order. 2000. "Mortgage Terminations, Heterogeneity and the Exercise of Mortgage Options.” Econometrica 68 (2): 275-307.

Dhar, Paramita, and Stephen L. Ross. 2012. "School District Quality and Property Values: Examining Differences along School District Boundaries.” Journal of Urban Economics 71 (1): 18-25.

Donald, Stephen G., and Kevin Lang. 2007. "Inference with Difference-in-Differences and Other Panel Data.” Review of Economics and Statistics 89 (2): 221-33.

Dube, Arindrajit, T. William Lester, and Michael Reich. 2010. "Minimum Wage Effects across State Borders: Estimates Using Contiguous Counties.” The Review of Economics and Statistics 92 (4): 945-964.

Duca, John V., and Anil Kumar. 2014. "Financial Literacy and Mortgage Equity Withdrawals." Journal of Urban Economics 80: 62-75. 
Duca, John V., John Muellbauer, and Anthony Murphy. 2010. "Housing Markets and the Financial Crisis of 2007-2009: Lessons for the Future.” Journal of Financial Stability 6 (4): 203217.

Elul, Ronel, Nicholas S. Souleles, Souphala Chomsisengphet, Dennis Glennon, and Robert Hunt. 2010. "What triggers mortgage Default?” The American Economic Review, 490-494.

Engelhardt, Gary V. 1996a. "House Prices and Home Owner Saving Behavior.” Regional Science and Urban Economics 26 (3): 313-336.

- 1996b. "Consumption, Down Payments, and Liquidity Constraints.” Journal of Money, Credit and Banking 28 (2): 255-71.

Foote, Christopher L., Kristopher Gerardi, and Paul S. Willen. 2008. "Negative Equity and Foreclosure: Theory and Evidence.” Journal of Urban Economics 64 (2): 234-245.

Gathergood, John. 2012. "Self-Control, Financial Literacy and Consumer over-Indebtedness." Journal of Economic Psychology 33 (3): 590-602.

Gerardi, Kristopher, Lorenz Goette, and Stephan Meier. 2010. "Financial Literacy and Subprime Mortgage Delinquency: Evidence from a Survey Matched to Administrative Data." Federal Reserve Bank of Atlanta Working Paper Series, no. 2010-10.

Ghent, Andra C., and Marianna Kudlyak. 2011. "Recourse and Residential Mortgage Default: Evidence from US States.” Review of Financial Studies 24 (9): 3139-3186.

Graham, Ann. 2007. "Where Agencies, the Courts, and the Legislature Collide: Ten Years of Interpreting the Texas Constitutional Provisions for Home Equity Lending.” Texas Tech Administrative Law Journal 9: 69-113.

Holmes, Thomas J. 1998. "The Effect of State Policies on the Location of Manufacturing: Evidence from State Borders.” Journal of Political Economy 106 (4): 667-705.

Hurst, Erik, and Frank Stafford. 2004. "Home Is Where the Equity Is: Mortgage Refinancing and Household Consumption.” Journal of Money, Credit and Banking, 985-1014.

Imbens, Guido, and Karthik Kalyanaraman. 2012. "Optimal Bandwidth Choice for the Regression Discontinuity Estimator.” The Review of Economic Studies 79 (3): 933-59.

Imbens, G.W., Zajonc, T., 2011. Regression Discontinuity Design With Multiple Forcing Variables. Working paper.

Jagtiani, Julapa, and William W. Lang. 2010. "Strategic Default on First and Second Lien Mortgages during the Financial Crisis.” Federal Reserve Bank of Philadelphia. http://www.phil.frb.org/research-and-data/publications/working-papers/2011/wp11-3.pdf.

Katz, Alyssa. 2010. “How Texas Escaped the Real Estate Crisis.” www.washingtonpost.com/wpdyn/content/article/2010/04/03/AR2010040304983.html.

Kau, James B., and Donald C. Keenan. 1995. "An Overview of the Option-Theoretic Pricing of Mortgages.” Journal of Housing Research 6 (2): 217-244.

Khandani, Amir E., Andrew W. Lo, and Robert C. Merton. 2013. "Systemic Risk and the Refinancing Ratchet Effect.” Journal of Financial Economics 108 (1): 29-45.

Kumar, Anil, and Edward C. Skelton. 2013. "Did Home Equity Restrictions Help Keep Texas Mortgages from Going Underwater?” The Southwest Economy, no. Q3: 3-7.

Laibson, David. 1997. “Golden Eggs and Hyperbolic Discounting.” The Quarterly Journal of Economics, 443-477.

Laufer, Steven. 2011. “Equity Extraction and Mortgage Default.” Working Paper. New York University.

Lee, David S, and Thomas Lemieux. 2010. "Regression Discontinuity Designs in Economics.” Journal of Economic Literature 48 (2): 281-355. 
Mayer, Christopher, Karen Pence, and Shane M. Sherlund. 2009. “The Rise in Mortgage Defaults.” The Journal of Economic Perspectives 23 (1): 27-50.

Mian, Atif, and Amir Sufi. 2011. "House Prices, Home Equity-Based Borrowing, and the US Household Leverage Crisis.” American Economic Review 101 (5): 2132-56.

Nichols, Austin. 2007. "Causal Inference with Observational Data.” Stata Journal 7 (4): 507.

Norris, Floyd. 2012. "Texas Lending Law Shielded Many Homeowners from Housing Bust." http://www.nytimes.com/2012/05/26/business/texas-lending-law-shielded-manyhomeowners-from-housing-bust.html.

Oster, E., 2014. Unobservable selection and coefficient stability: Theory and evidence. Journal of Business Economics and Statistics, forthcoming.

Pence, Karen M. 2006. "Foreclosing on Opportunity: State Laws and Mortgage Credit." Review of Economics and Statistics 88 (1): 177-182.

Pennington-Cross, Anthony, and Souphala Chomsisengphet. 2007. "Subprime Refinancing: Equity Extraction and Mortgage Termination.” Real Estate Economics 35 (2): 233-263.

Pisati, Maurizio. 2001. "sg162: Tools for Spatial Data Analysis.” Stata Technical Bulletin 60: 2137.

Quercia, Roberto G., and Michael A. Stegman. 1992. "Residential Mortgage Default: A Review of the Literature." Journal of Housing Research 3 (2): 341-379.

Saiz, Albert. 2010. "The Geographic Determinants of Housing Supply.” The Quarterly Journal of Economics 125 (3): 1253-1296.

Sinai, Todd, and Nicholas S. Souleles. 2005. "Owner-Occupied Housing as a Hedge Against Rent Risk.” The Quarterly Journal of Economics 120 (2): 763-89.

Tibshirani, Robert. 1996. "Regression Shrinkage and Selection via the Lasso." Journal of the Royal Statistical Society. Series B (Methodological), 267-288.

Vandell, Kerry D., and Thomas Thibodeau. 1985. "Estimation of Mortgage Defaults Using Disaggregate Loan History Data.” Real Estate Economics 13 (3): 292-316.

Vicente, Fernando López. 2013. "The Effect of Foreclosure Regulation: Evidence for the US Mortgage Market at State Level.” Banco de Espa a. http://ideas.repec.org/p/bde/wpaper/1306.html.

Wooldridge, Jeffrey M. 2003. "Cluster-Sample Methods in Applied Econometrics." American Economic Review 93 (2): 133-38. 
Figure 1

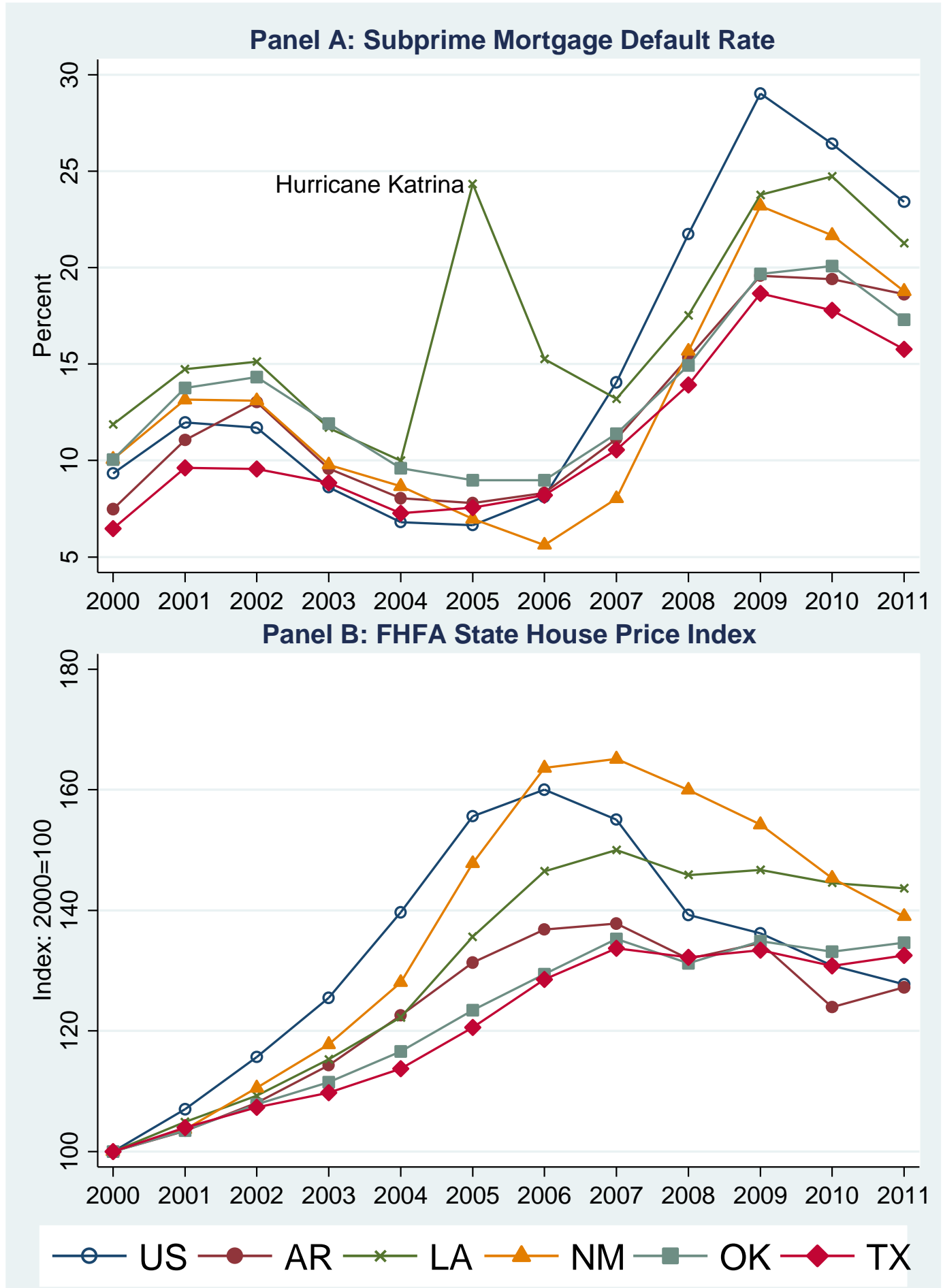

Note: Subprime mortgage default rates plotted in the chart are percent of subprime mortgages 90plus days delinquent or in foreclosure inventory from Haver Analytics based on data from Mortgage Bankers Association. The state-level house price index plotted in Panel B is from the Federal Housing Finance Agency (FHFA). 
Figure 2

\section{Counties Near Texas Border}

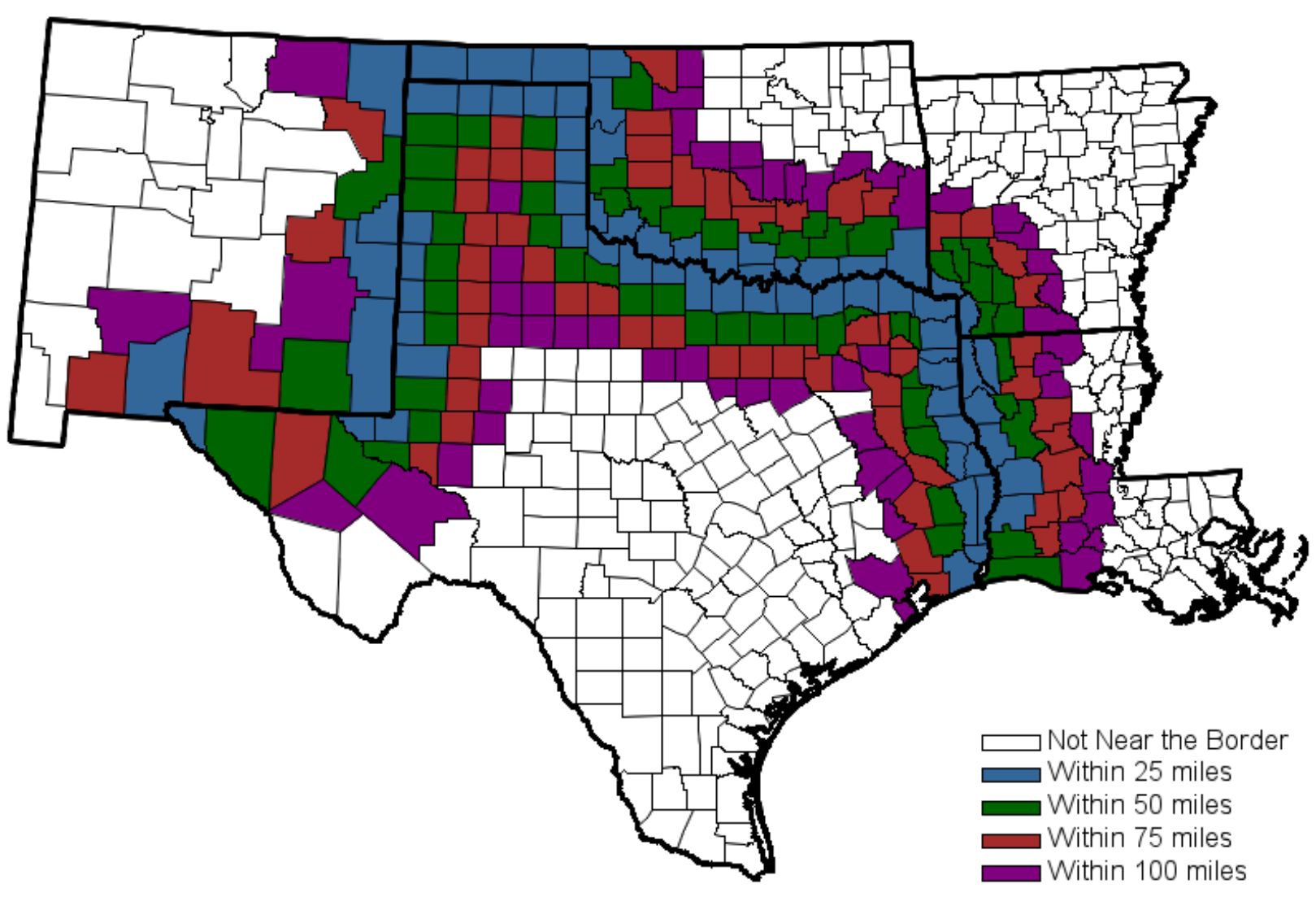


Figure 3

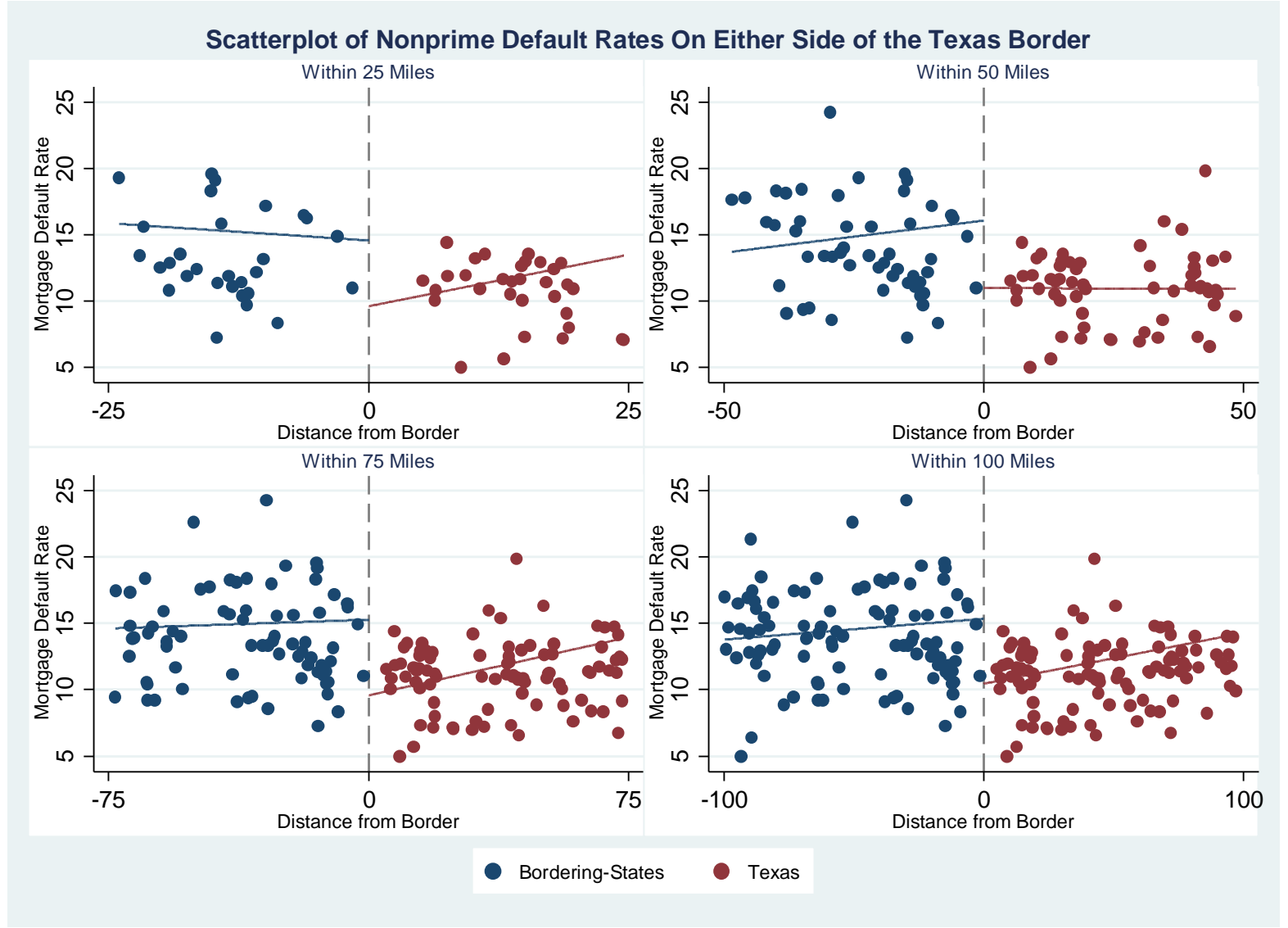

Note: The figure plots average county-level nonprime mortgage default rates from 2007 to 2011 for each discrete value of minimum distance from the Texas border (normalized to zero at the border). The plots are based on author's calculation using ABS data from the RADAR data warehouse. Mortgages in default are defined as those 90-plus days delinquent or in foreclosure or real estate owned (REO). Linear fitted lines are based on regression of 20072011 average of county-level mortgage default rates on a linear polynomial in distance weighted by number of nonprime loans. 


\section{Figure 4}

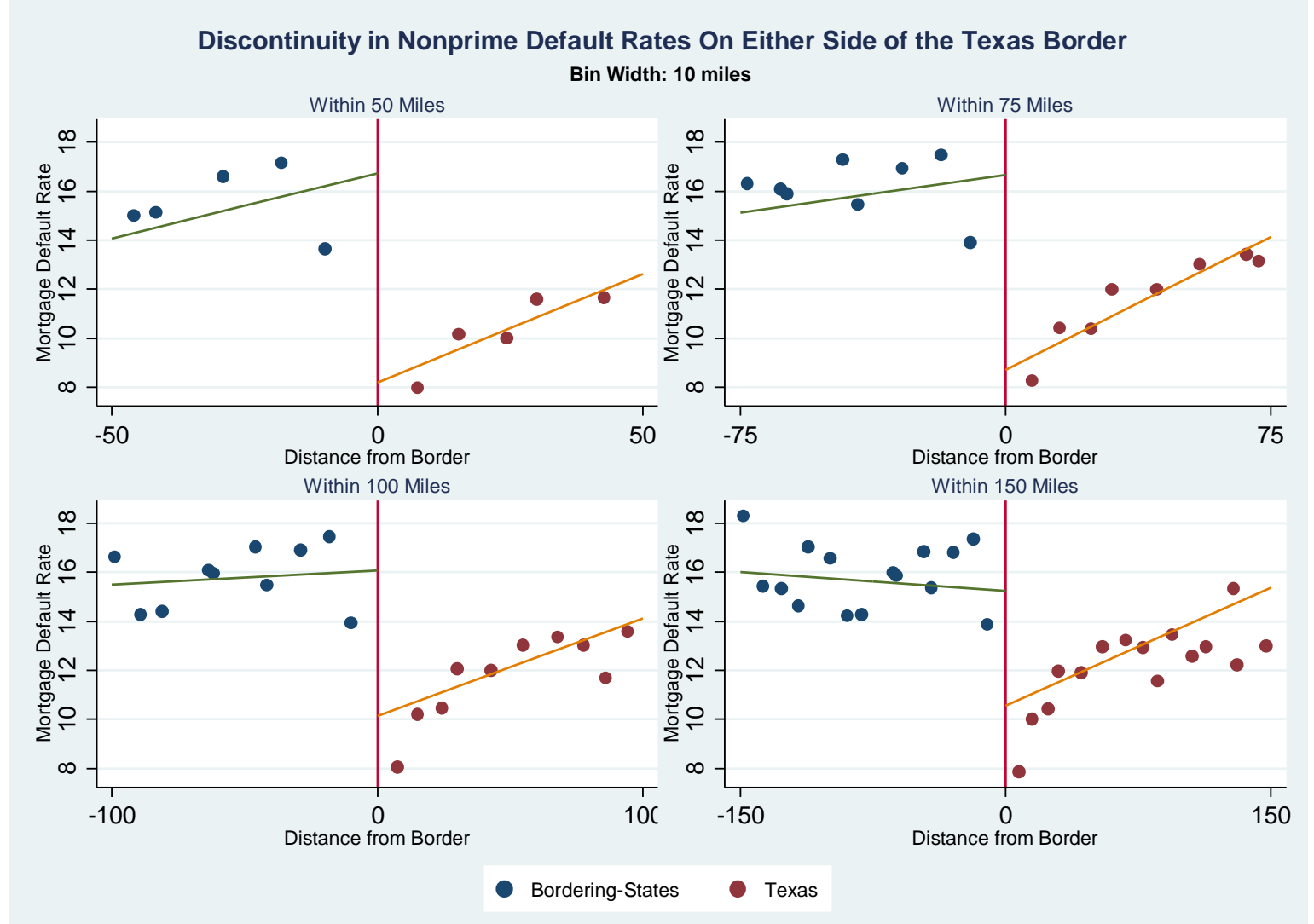

Note: The figure plots the conditional mean of the county-level nonprime mortgage default rate from 2007 to 2011 (controlling for baseline covariates: unemployment, initial FICO, and house price change) within 10-mile wide bins. Linear fitted lines are based on regression of county-level mortgage default rate (residualized by subtracting the prediction from a regression of mortgage default rate on baseline covariates) from 2007 to 2011 on a linear polynomial in distance. Mortgages in default are defined as those 90-plus day delinquent or in foreclosure or real estate owned (REO). All estimates are weighted by county-level number of nonprime loans. Sources of data are: county-level nonprime default rate and initial FICO calculated using ABS data from RADAR data warehouse; county unemployment rate from BLS/LAUS; county-level house price index from CoreLogic. 
Figure 5

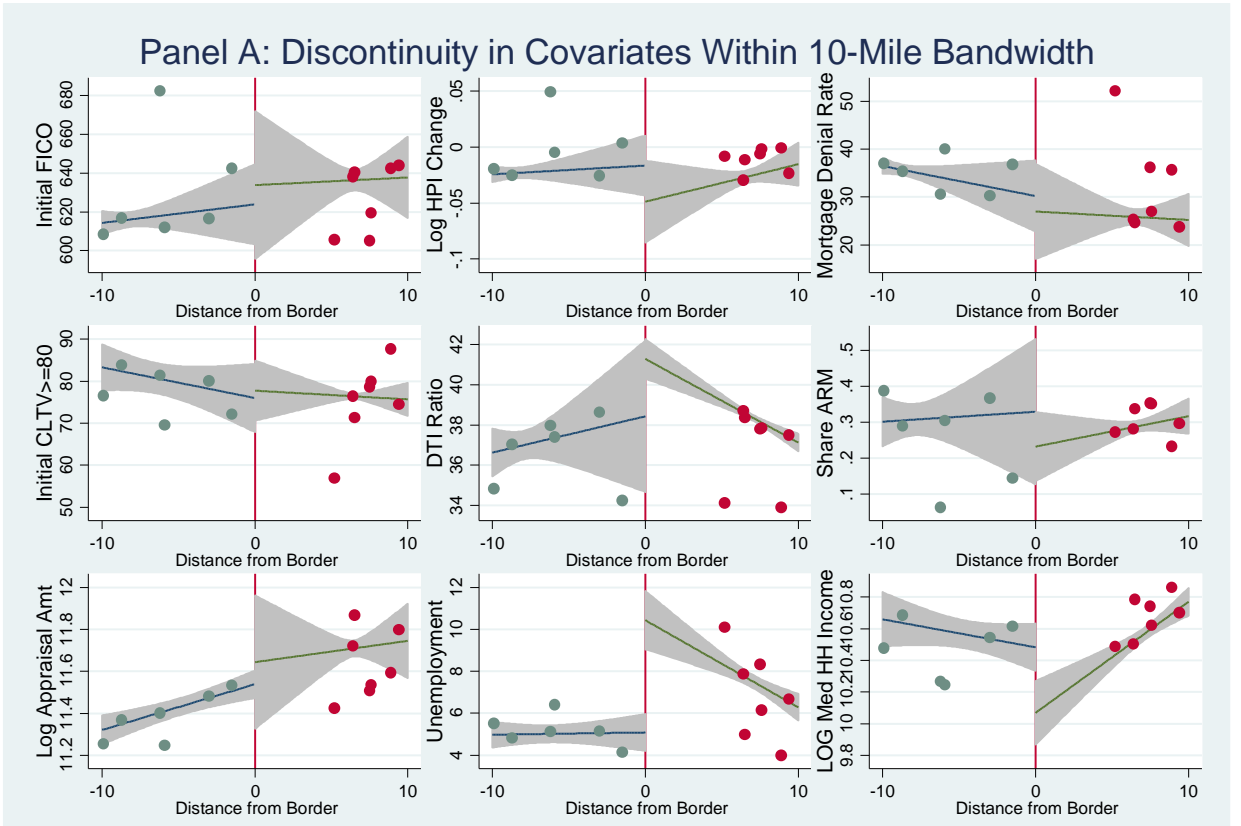

Panel B: Discontinuity in Covariates Within MSE-Optimal 78-Mile Bandwidth
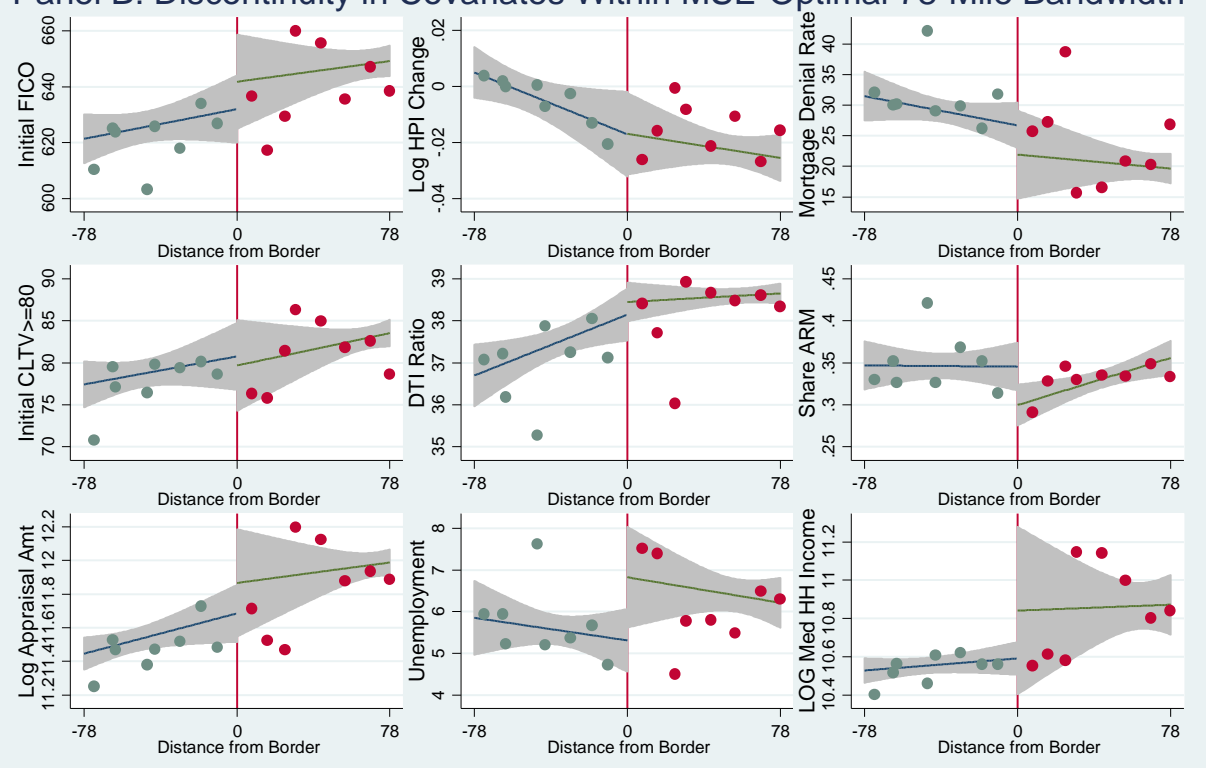

Bordering-States

Texas

Note: All calculations are based on county-level data from 2007 to 2011. The figure plots binned means of baseline covariates (conditional on year effects) within 1-mile bins (Panel A) and 10-mile bins (Panel B). Linear fitted lines are from a simple regression of the relevant variable--residualized of year dummies-- on a linear polynomial in distance. All estimates are weighted by county-level number of nonprime loans. The 95 percent confidence bands are based on standard errors clustered at the county level. Sources of data: county-level initial FICO, initial CLTV, Debt-to-Income (DTI) Ratio, share ARM, and Log appriasal amount at origination calculated using ABS data from RADAR data warehouse; county unemployment rate and median household income from BLS/LAUS; county-level house price index from CoreLogic; mortgage denial rates calculated using HMDA data available from the Urban Institute. The shaded regions are 95 percent confidence intervals of the fitted lines. 


\section{Figure 6}

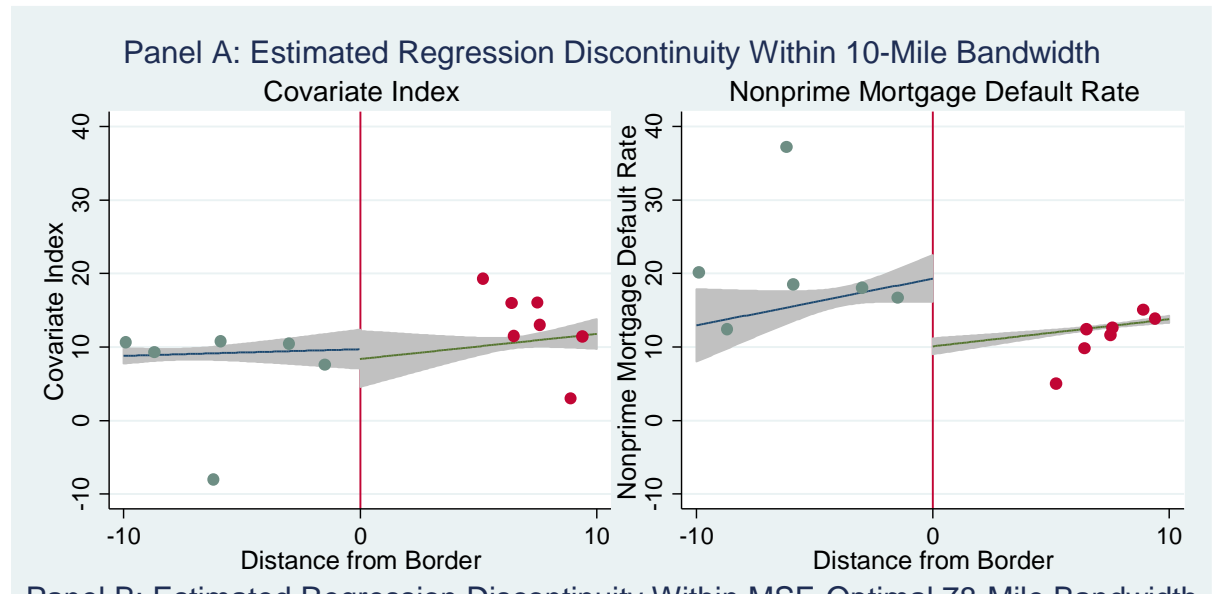

Panel B: Estimated Regression Discontinuity Within MSE-Optimal 78-Mile Bandwidth
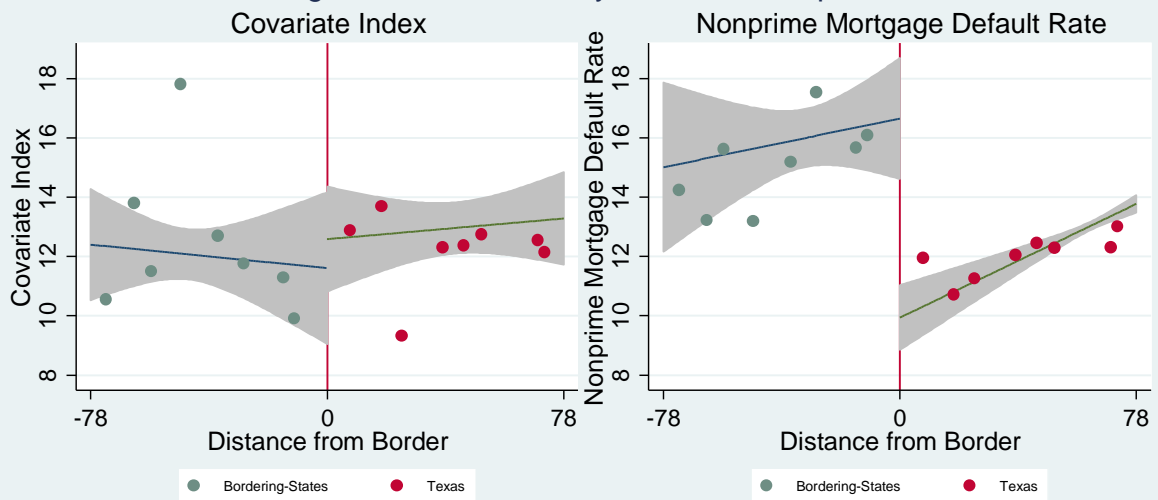

Panel C: Estimated Regression Discontinuity by Bandwidth

Covariate Index
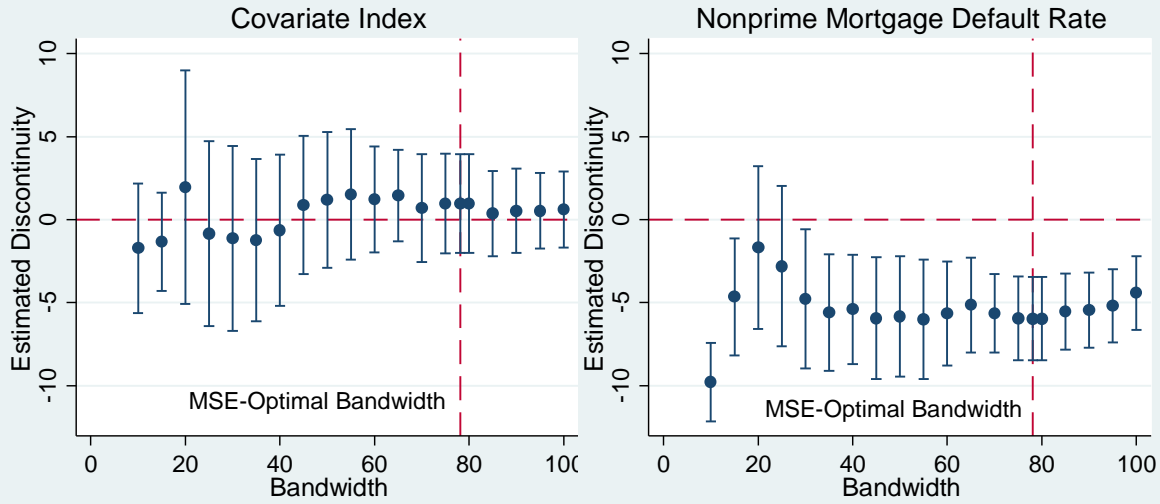

Note: All calculations are based on county-level data from 2007 to 2011. The left panels of the figure show the discontinuity in the "covariate index" proposed in Card, Lee, Pei, and Weber (2012), constructed as the predicted outcome from a simple regression of the outcome variable-mortgage default rate - on the following variables: initial FICO, lagged house price change, mortgage denial rate, share of borrowers with initial CLTV 80 percent or higher, share of ARMs, unemployment rate, and median household income. The right panels show the discontnuity in county-level nonprime mortgage default rate (controlling for covariates used in the construction of the "covariate index"). Binned means are for 1-mile bins in Panel A and 10-mile wide bins in Panel B. Fitted lines in the right panels are for mortgage default rate adjusted for covariates by residualizing. The 95 percent confidence bands are based on standard errors clustered at the county level. Panel C plots RD estimates with their 95 percent confidence bands from regression specifications analogous to those used for the linear fits in Panel A and B. All estimates are weighted by county-level number of nonprime loans. See notes to Figures 4 and 6 and pages 7-9 for sources of data. 
Figure 7

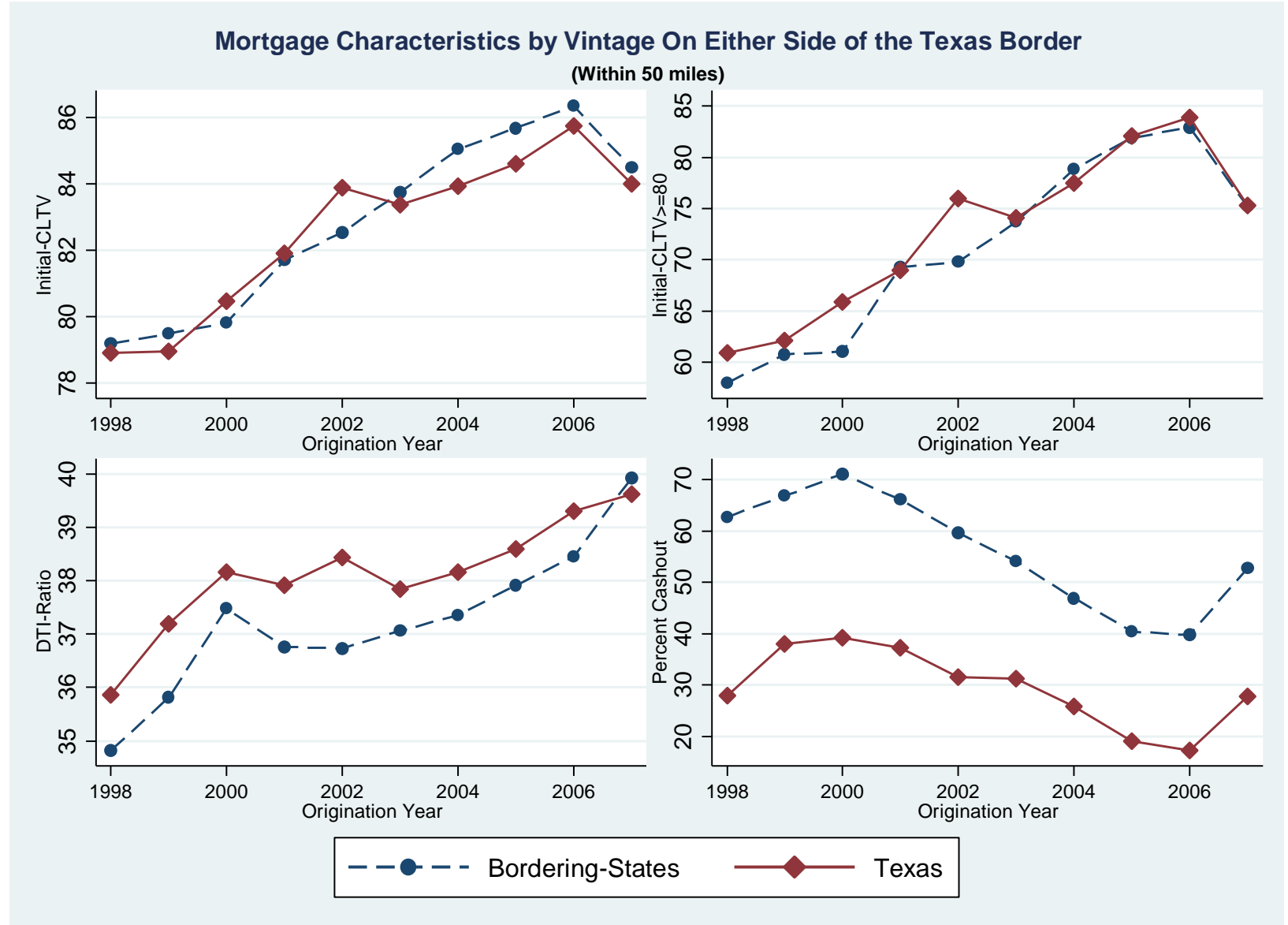

Plotted means of mortgage characteristics are based on county-level data on nonprime mortgages created using ABS database from the RADAR data warehouse. 
Figure 8

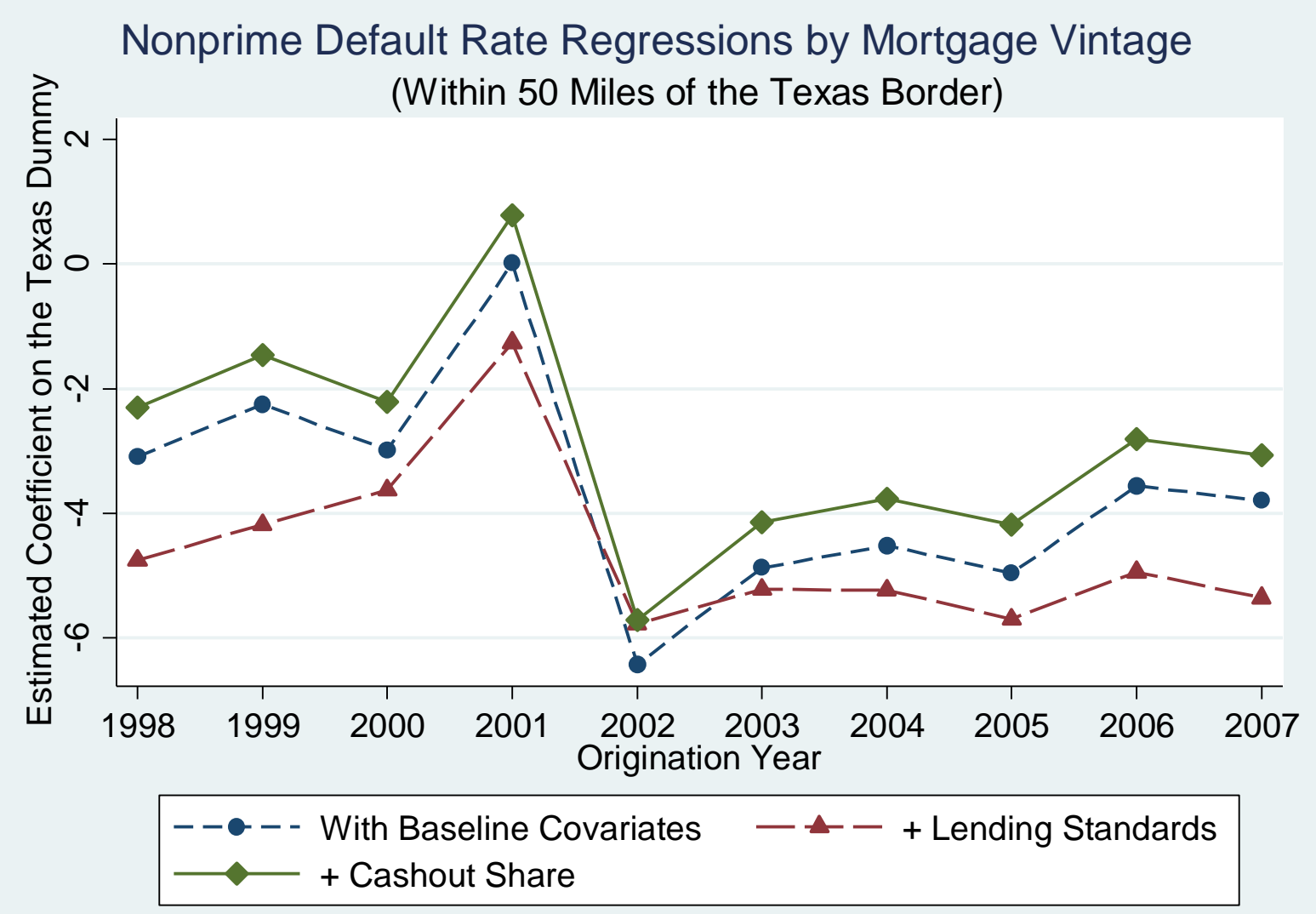

Estimates based on data on nonprime mortgages from ABS database. Baseline covariates consist of county unemployment rate, 1-year lagged log house price change (Lagged $\Delta$ HPI), county-level initial FICO score, and year effects. Estimates weighted by number of loans in each county-vintage-year cell. The coefficient on the Texas dummy should be interpreted as the difference in mortgage default rate on the Texas side of the border vis-a-vis NM, OK, AR, and LA side of the border. 


\section{Figure 9}

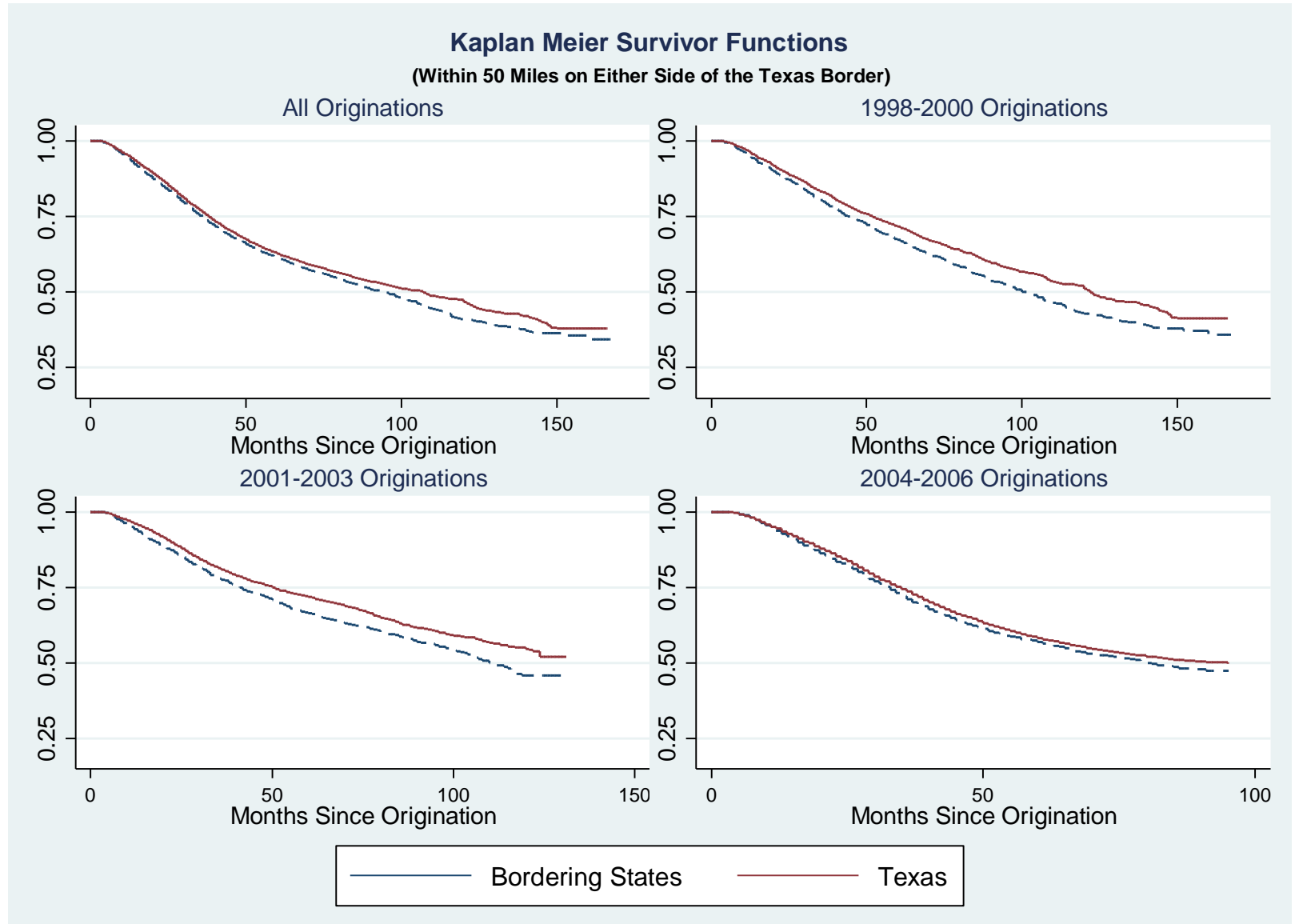

Source: ABS data from RADAR data warehouse; author's calculations. 
Table 1: Summary Statistics

\begin{tabular}{|c|c|c|c|c|c|c|}
\hline & 25 Miles & 25 Miles & 50 Miles & 50 Miles & All & All \\
\hline & Texas & $\begin{array}{c}\text { Texas } \\
\text { minus } \\
\text { Bordering } \\
\text { States }\end{array}$ & Texas & $\begin{array}{c}\text { Texas } \\
\text { minus } \\
\text { Bordering } \\
\text { States }\end{array}$ & Texas & $\begin{array}{c}\text { Texas } \\
\text { minus } \\
\text { Bordering } \\
\text { States }\end{array}$ \\
\hline \multicolumn{7}{|l|}{ A: All Mortgages } \\
\hline Mortgage Default Rate & $\begin{array}{c}4.01 \\
(1.28)\end{array}$ & $\begin{array}{l}-1.04 \\
(0.79)\end{array}$ & $\begin{array}{c}3.60 \\
(1.14)\end{array}$ & $\begin{array}{l}-1.45^{* *} \\
(0.52)\end{array}$ & $\begin{array}{c}4.25 \\
(1.45)\end{array}$ & $\begin{array}{l}-0.63^{*} \\
(0.31)\end{array}$ \\
\hline Initial FICO & $\begin{array}{l}684.51 \\
(5.90)\end{array}$ & $\begin{array}{l}-7.17 \\
(5.28)\end{array}$ & $\begin{array}{r}700.10 \\
(14.72) \\
\end{array}$ & $\begin{array}{l}10.48 \\
(6.75)\end{array}$ & $\begin{array}{l}697.05 \\
(11.75)\end{array}$ & $\begin{array}{l}-1.77 \\
(2.63)\end{array}$ \\
\hline \multicolumn{7}{|l|}{ B: Nonprime Mortgages } \\
\hline Mortgage Default Rate & $\begin{array}{l}11.09 \\
(4.00)\end{array}$ & $\begin{array}{l}-4.32^{*} \\
(1.73)\end{array}$ & $\begin{array}{l}10.94 \\
(3.57)\end{array}$ & $\begin{array}{l}-4.06^{* * *} \\
(1.18)\end{array}$ & $\begin{array}{l}12.63 \\
(3.82)\end{array}$ & $\begin{array}{l}-2.72^{* * *} \\
(0.70)\end{array}$ \\
\hline Share ARM & $\begin{array}{c}0.30 \\
(0.04)\end{array}$ & $\begin{array}{l}-0.04^{*} \\
(0.02)\end{array}$ & $\begin{array}{c}0.32 \\
(0.03)\end{array}$ & $\begin{array}{l}-0.02 \\
(0.01)\end{array}$ & $\begin{array}{c}0.32 \\
(0.03)\end{array}$ & $\begin{array}{l}-0.04^{* * *} \\
(0.01)\end{array}$ \\
\hline Percent Cash-out & $\begin{array}{l}34.88 \\
(4.49)\end{array}$ & $\begin{array}{l}-12.47^{* * *} \\
(2.14)\end{array}$ & $\begin{array}{c}23.64 \\
(10.13)\end{array}$ & $\begin{array}{l}-25.30^{* * *} \\
(4.02)\end{array}$ & $\begin{array}{l}25.32 \\
(6.41)\end{array}$ & $\begin{array}{l}-20.97^{* * *} \\
(1.29)\end{array}$ \\
\hline DTI-Ratio & $\begin{array}{l}38.19 \\
(0.86)\end{array}$ & $\begin{array}{c}0.31 \\
(0.36)\end{array}$ & $\begin{array}{l}38.58 \\
(0.72)\end{array}$ & $\begin{array}{l}0.83^{* *} \\
(0.26)\end{array}$ & $\begin{array}{l}38.71 \\
(0.60)\end{array}$ & $\begin{array}{l}1.05^{* * *} \\
(0.15)\end{array}$ \\
\hline Initial FICO & $\begin{array}{l}630.89 \\
(12.68)\end{array}$ & $\begin{array}{l}-1.99 \\
(7.35)\end{array}$ & $\begin{array}{l}648.62 \\
(19.83)\end{array}$ & $\begin{array}{l}19.59^{*} \\
(7.92)\end{array}$ & $\begin{array}{l}644.32 \\
(13.58)\end{array}$ & $\begin{array}{c}4.20 \\
(4.02)\end{array}$ \\
\hline Initial-CLTV & $\begin{array}{l}85.75 \\
(0.98)\end{array}$ & $\begin{array}{l}-1.84^{*} \\
(0.74)\end{array}$ & $\begin{array}{l}88.47 \\
(2.37)\end{array}$ & $\begin{array}{c}0.98 \\
(1.03)\end{array}$ & $\begin{array}{l}88.13 \\
(1.72)\end{array}$ & $\begin{array}{l}1.26^{* *} \\
(0.45)\end{array}$ \\
\hline Initial-CLTV $\geq 80 \%$ & $\begin{array}{l}76.21 \\
(2.60)\end{array}$ & $\begin{array}{l}-3.65 \\
(1.98)\end{array}$ & $\begin{array}{l}82.41 \\
(5.41)\end{array}$ & $\begin{array}{l}2.65 \\
(2.43)\end{array}$ & $\begin{array}{l}81.44 \\
(4.13)\end{array}$ & $\begin{array}{l}2.87^{*} \\
(1.16)\end{array}$ \\
\hline Underwater (CLTV $\geq 110$ ) & $\begin{array}{l}5.30 \\
(6.69)\end{array}$ & $\begin{array}{l}-7.94^{* *} \\
(2.72)\end{array}$ & $\begin{array}{c}9.84 \\
(6.44)\end{array}$ & $\begin{array}{l}-0.73 \\
(3.04)\end{array}$ & $\begin{array}{l}15.67 \\
(10.47)\end{array}$ & $\begin{array}{c}0.82 \\
(2.39)\end{array}$ \\
\hline Underwater (CLTV $\geq 120)$ & $\begin{array}{c}2.95 \\
(6.35)\end{array}$ & $\begin{array}{l}-6.99^{*} \\
(3.27)\end{array}$ & $\begin{array}{c}4.21 \\
(4.28)\end{array}$ & $\begin{array}{l}-3.50 \\
(2.78)\end{array}$ & $\begin{array}{c}7.25 \\
(6.25) \\
\end{array}$ & $\begin{array}{c}-1.16 \\
(1.34) \\
\end{array}$ \\
\hline C: Other Characteristics & & & & & & \\
\hline HPI-Change(2007-2011) & $\begin{array}{c}-0.14 \\
(0.02)\end{array}$ & $\begin{array}{c}-0.08 \\
(0.07)\end{array}$ & $\begin{array}{c}-0.11 \\
(0.03)\end{array}$ & $\begin{array}{c}-0.05 \\
(0.05)\end{array}$ & $\begin{array}{l}-0.10 \\
(0.04)\end{array}$ & $\begin{array}{c}-0.02 \\
(0.02)\end{array}$ \\
\hline Unemp & $\begin{array}{c}7.51 \\
(2.11)\end{array}$ & $\begin{array}{c}2.00^{* * *} \\
(0.39)\end{array}$ & $\begin{array}{c}6.34 \\
(2.00)\end{array}$ & $\begin{array}{c}0.89^{*} \\
(0.44)\end{array}$ & $\begin{array}{c}6.36 \\
(1.93)\end{array}$ & $\begin{array}{c}0.70^{* * *} \\
(0.16)\end{array}$ \\
\hline LOG-MedHHI & $\begin{array}{l}10.57 \\
(0.10)\end{array}$ & $\begin{array}{c}0.01 \\
(0.05)\end{array}$ & $\begin{array}{l}10.95 \\
(0.33)\end{array}$ & $\begin{array}{l}0.37^{* *} \\
(0.14)\end{array}$ & $\begin{array}{l}10.84 \\
(0.22)\end{array}$ & $\begin{array}{c}0.18^{* * *} \\
(0.04)\end{array}$ \\
\hline Mortgage Denial Rate & $\begin{array}{l}26.30 \\
(5.24)\end{array}$ & $\begin{array}{c}-0.95 \\
(1.65)\end{array}$ & $\begin{array}{c}19.60 \\
(8.42)\end{array}$ & $\begin{array}{l}-8.54^{* *} \\
(3.15)\end{array}$ & $\begin{array}{l}21.15 \\
(5.27)\end{array}$ & $\begin{array}{c}-2.31 \\
(1.21)\end{array}$ \\
\hline
\end{tabular}

Standard deviations presented in parenthesis. Summary statistics in Panel A based on data on all residential mortgages from Mcdash/Lender Processing Services (LPS) and Panel B on data on nonprime mortgages from ABS database from RADAR warehouse. For data sources in Panel C, see page 8. 
Table 2: Baseline Estimates of Effect of Texas Home Equity Restrictions on Mortgage Default using One-dimensional RD (Dependent Variable: County-Level Default Rate)

\begin{tabular}{|c|c|c|c|c|c|c|c|c|c|c|}
\hline & $\begin{array}{c}(1) \\
<25 \\
\text { miles } \\
\end{array}$ & $\begin{array}{c}(2) \\
<25 \\
\text { miles } \\
\end{array}$ & $\begin{array}{c}(3) \\
<50 \\
\text { miles } \\
\end{array}$ & $\begin{array}{c}\quad(4) \\
<50 \\
\text { miles } \\
\end{array}$ & $\begin{array}{c}5) \\
<75 \\
\text { miles } \\
\end{array}$ & $\begin{array}{c}(6) \\
<75 \\
\text { miles } \\
\end{array}$ & $\begin{array}{c}(7) \\
<100 \\
\text { miles } \\
\end{array}$ & $\begin{array}{c}(8) \\
<100 \\
\text { miles } \\
\end{array}$ & $\begin{array}{l}\text { (9) } \\
\text { All }\end{array}$ & $\begin{array}{c}(10) \\
\text { All }\end{array}$ \\
\hline \multicolumn{11}{|c|}{ Panel A: All Mortgages } \\
\hline \multirow[t]{2}{*}{ Texas } & -2.594 & -2.035 & -0.655 & $-2.360 * *$ & $-2.554 * *$ & $-3.130 * *$ & $-2.064 * *$ & $-2.176 * *$ & 0.082 & -0.084 \\
\hline & $(1.567)$ & $(1.255)$ & $(0.845)$ & $(1.096)$ & $(0.826)$ & $(0.660)$ & $(0.666)$ & $(0.568)$ & $(0.598)$ & $(0.361)$ \\
\hline Observations & 310 & 310 & 568 & 568 & 828 & 828 & 1072 & 1072 & 2250 & 2250 \\
\hline N_counties & 64.00 & 64.00 & 116.00 & 116.00 & 169.00 & 169.00 & 218.00 & 218.00 & 456.00 & 456.00 \\
\hline $\mathrm{R}-\mathrm{Sq}$ & 0.53 & 0.66 & 0.61 & 0.71 & 0.53 & 0.76 & 0.61 & 0.77 & 0.47 & 0.70 \\
\hline \multicolumn{11}{|c|}{ Panel B: Nonprime Mortgages } \\
\hline Texas & $\begin{array}{l}-6.425^{*} \\
(3.501)\end{array}$ & $\begin{array}{c}-2.623 \\
(2.421)\end{array}$ & $\begin{array}{c}-4.499 * * \\
(1.881)\end{array}$ & $\begin{array}{c}-6.897 * * \\
(2.312)\end{array}$ & $\begin{array}{c}-6.847^{* *} \\
(1.380)\end{array}$ & $\begin{array}{c}-8.134 * * \\
(1.245)\end{array}$ & $\begin{array}{c}-5.618 * * \\
(1.230)\end{array}$ & $\begin{array}{c}-6.676 * * \\
(1.123) \\
\end{array}$ & $\begin{array}{c}-1.249 \\
(1.059)\end{array}$ & $\begin{array}{c}-1.364^{*} \\
(0.765)\end{array}$ \\
\hline Observations & 310 & 310 & 569 & 569 & 829 & 829 & 1073 & 1073 & 2252 & 2252 \\
\hline N_counties & 64 & 64 & 117 & 117 & 170 & 170 & 219 & 219 & 457 & 457 \\
\hline $\mathrm{R}-\mathrm{Sq}$ & 0.71 & 0.77 & 0.76 & 0.79 & 0.74 & 0.81 & 0.79 & 0.83 & 0.71 & 0.77 \\
\hline Linear in Distance & Yes & Yes & Yes & Yes & Yes & Yes & Yes & Yes & Yes & Yes \\
\hline Year Effects & Yes & Yes & Yes & Yes & Yes & Yes & Yes & Yes & Yes & Yes \\
\hline Baseline Covariates & No & Yes & No & Yes & No & Yes & No & Yes & No & Yes \\
\hline $\begin{array}{l}\text { *Significant at } 10 \% \text { level; } \\
\text { share of mortgages } 90 \text {-plu } \\
2007 \text { to } 2011 \text { on the Texas } \\
\text { covariates included are the } \\
\text { weighted by number of lo } \\
\text { Texas side of the border v } \\
\text { with respective states. Re }\end{array}$ & $\begin{array}{l}\text { *Significar } \\
\text { days delins } \\
\text { ummy and } \\
\text { ounty unen } \\
\text { ns in each } \\
\text {-a-vis NM, } \\
\text { lts in Pane }\end{array}$ & $\begin{array}{l}5 \% \text { level. } \\
\text { nt or in fo } \\
\text { near RD p } \\
\text { yment rat } \\
\text { nty-year c } \\
\text { AR, and } \\
\text { are based }\end{array}$ & $\begin{array}{l}\text { bust stand } \\
\text { osure or } \mathrm{R} \\
\text { omial in } \mathrm{m} \\
\text { year lagge } \\
\text { The coeff } \\
\text { side of the } \\
\text { data on al }\end{array}$ & $\begin{array}{l}\text { errors cluste } \\
\text {. Results pr } \\
\text { mum distan } \\
\text { g house pric } \\
\text { nt on the Te } \\
\text { rder. Data f }\end{array}$ & $\begin{array}{l}\text { to the Texas } \\
\text { change (Lag } \\
\text { m Holmes (1 }\end{array}$ & $\begin{array}{l}\text { order (norm } \\
\mathrm{d} \Delta \mathrm{HPI} \text { ), col } \\
\text { uld be inter } \\
\text { 8) was usec }\end{array}$ & $\begin{array}{l}\text { he depenc } \\
\text { ion of cou } \\
\text { zed to zerc } \\
\text { y-level ini } \\
\text { ted as the } \\
\text { get dista }\end{array}$ & $\begin{array}{l}\text { variable mo } \\
\text { year level } \\
\text { he border). } \\
\text { FICO score } \\
\text { continuity } \\
\text { of county }\end{array}$ & $\begin{array}{l}\text { age defau } \\
\text { tgage def } \\
\text { ler county } \\
\text { d year eff } \\
\text { nortgage } \\
\text { roid to th }\end{array}$ & $\begin{array}{l}\text { defined a } \\
\text { rates from } \\
\text { el baselin } \\
\text { Estimate } \\
\text { ult rate or } \\
\text { xas borde }\end{array}$ \\
\hline
\end{tabular}


Table 3: Effect of Texas Home Equity Restrictions on Mortgage Default using Multidimensional RD

(Dependent Variable: County-Level Default Rate) (Data: LPS Data on All Mortgages Grouped to County Level)

\begin{tabular}{|c|c|c|c|c|c|}
\hline & (1) & (2) & (3) & (4) & (5) \\
\hline Distance Band & $<25$ & $<50$ & $\begin{array}{c}<75 \\
\text { miles }\end{array}$ & $<100$ & All \\
\hline \multicolumn{6}{|c|}{ Panel A: Linear Polynomial in Latitude and Longitude } \\
\hline Texas & $\begin{array}{c}-1.532 * * \\
(0.357)\end{array}$ & $\begin{array}{c}-1.401 * * \\
(0.379)\end{array}$ & $\begin{array}{c}-1.106^{* *} \\
(0.409)\end{array}$ & $\begin{array}{l}-0.580^{*} \\
(0.324)\end{array}$ & $\begin{array}{c}-0.920^{* *} \\
(0.213)\end{array}$ \\
\hline \multicolumn{6}{|c|}{ Panel B: Quadratic Polynomial in Latitude and Longitude } \\
\hline Texas & $\begin{array}{c}-1.189 * * \\
(0.311)\end{array}$ & $\begin{array}{c}-1.185^{* *} \\
(0.328)\end{array}$ & $\begin{array}{c}-1.011^{* *} \\
(0.356)\end{array}$ & $\begin{array}{c}-1.037^{* *} \\
(0.328)\end{array}$ & $\begin{array}{c}-1.045^{* *} \\
(0.257)\end{array}$ \\
\hline \multicolumn{6}{|c|}{ Panel C: Cubic Polynomial in Latitude and Longitude } \\
\hline Texas & $\begin{array}{c}-1.339 * * \\
(0.345)\end{array}$ & $\begin{array}{c}-1.480 * * \\
(0.391)\end{array}$ & $\begin{array}{c}-1.421^{* *} \\
(0.330)\end{array}$ & $\begin{array}{c}-1.020^{* *} \\
(0.289)\end{array}$ & $\begin{array}{c}-1.167^{* *} \\
(0.260)\end{array}$ \\
\hline \multicolumn{6}{|c|}{ Panel D: Polynomial in Latitude and Longitude using post-double-LASSO ${ }^{\S}$} \\
\hline Texas & $\begin{array}{c}-1.678^{* *} \\
(0.447)\end{array}$ & $\begin{array}{c}-1.463^{* *} \\
(0.413)\end{array}$ & $\begin{array}{c}-0.804^{*} \\
(0.429)\end{array}$ & $\begin{array}{l}-0.591 * \\
(0.321)\end{array}$ & $\begin{array}{c}-0.700^{* *} \\
(0.207)\end{array}$ \\
\hline $\begin{array}{l}\text { LASSO Selected } \\
\text { Polynomial Terms }\end{array}$ & $X$ & $X$ & None & $X, Y, X Y$ & $X, Y, X Y$ \\
\hline Observations & 310 & 568 & 828 & 1072 & 2250 \\
\hline Count & 64 & 116 & 169 & 218 & 456 \\
\hline$R$-Square & 0.8489 & 0.8499 & 0.8489 & 0.8718 & 0.8287 \\
\hline Other C & Yes & Yes & Yes & Yes & Yes \\
\hline & Yes & Yes & Yes & Yes & Yes \\
\hline Border FE & Yes & Yes & Yes & Yes & Yes \\
\hline
\end{tabular}

*Significant at $10 \%$ level; **Significant at 5\% level. Robust standard errors clustered by county in parenthesis. The dependent variable mortgage default is defined as share of mortgages 90-plus days delinquent or in foreclosure or REO. Results presented are from linear regression of countyyear level mortgage default rates from 2007 to 2011 on the Texas dummy and multidimensional RD polynomial in latitude and longitude. Other county-level baseline covariates included are the county unemployment rate, 1-year lagged log house price change (Lagged $\Delta \mathrm{HPI}$ ), county-level initial FICO score, share of mortgages with initial LTV 80 percent or higher, county-level log median household income, share of adjustable rate mortgages, share of cash-out refinance mortgages, and average county-level mortgage denial rate between 2000 and 2006, year effects, and state border-segment fixed effects. Estimates are weighted by number of loans in each countyyear cell. The coefficient on the Texas dummy should be interpreted as the discontinuity in mortgage default rate on the Texas side of the border vis-a-vis NM, OK, AR, and LA side of the border. Data from Holmes (1998) was used to get distances of county centroid to the Texas border with respective states. Data on county-level default rates and other mortgage characteristics are from a database on all residential mortgages from McDash/Lender Processing Services (LPS).

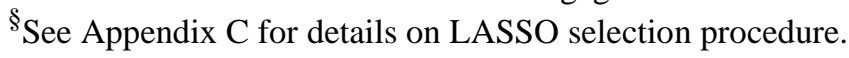


Table 4: Effect of Texas Home Equity Restrictions on Mortgage Default using Multidimensional RD

(Dependent Variable: County-Level Default Rate)

(Data: ABS Data on Nonprime Mortgages Grouped to County Level)

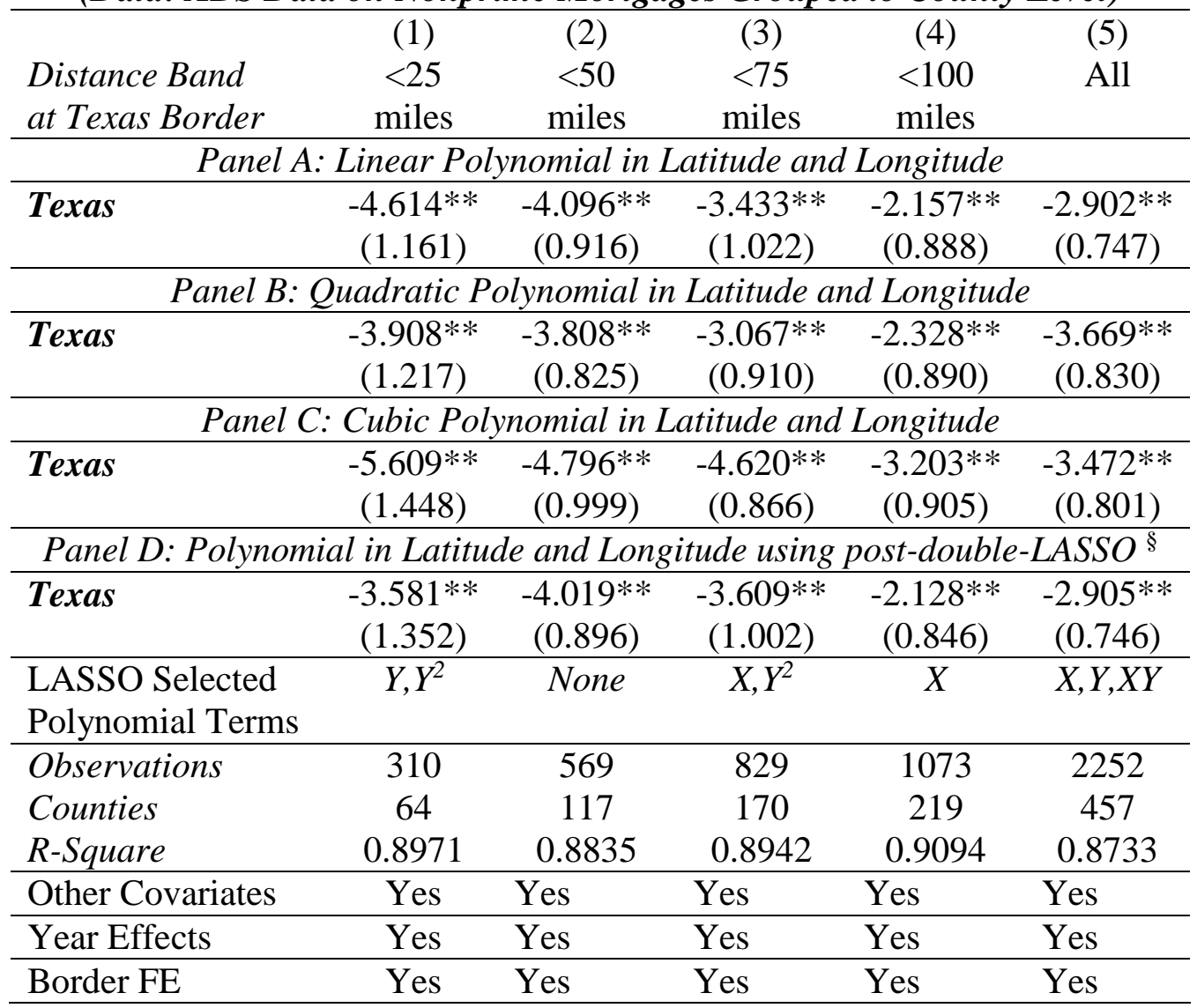

*Significant at $10 \%$ level; **Significant at 5\% level. Robust standard errors clustered by county are in parenthesis. The dependent variable mortgage default is defined as share of mortgages 90plus days delinquent or in foreclosure or REO. Results presented are from linear regression of county-year level mortgage default rates from 2007 to 2011 on the Texas dummy and multidimensional RD polynomial in latitude and longitude. Other county-level baseline covariates included are the county unemployment rate, 1 -year lagged log house price change (Lagged $\Delta \mathrm{HPI}$ ), county-level initial FICO score, share of mortgages with initial CLTV 80 percent or higher, county-level log median household income, share of adjustable rate mortgages, share of cash-out refinance mortgages, and average county-level mortgage denial rate between 2000 and 2006, year effects, and state border-segment fixed effects. Estimates weighted by number of loans in each county-year cell. The coefficient on the Texas dummy should be interpreted as the discontinuity in mortgage default rate on the Texas side of the border vis-a-vis NM, OK, AR, and LA side of the border. Data from Holmes (1998) was used to get distances of county centroid to the Texas border with respective states. Data on county-level nonprime default rates and other mortgage characteristics are from ABS database on nonprime mortgages from CoreLogic. ${ }^{\S}$ See Appendix C for details on LASSO selection procedure. 
Table 5: Effect of Texas Home Equity Restrictions on Nonprime Mortgage Default Hazard using Multidimensional RD

(Cox Proportional Hazard Model of Nonprime Mortgage Default using ABS Data)

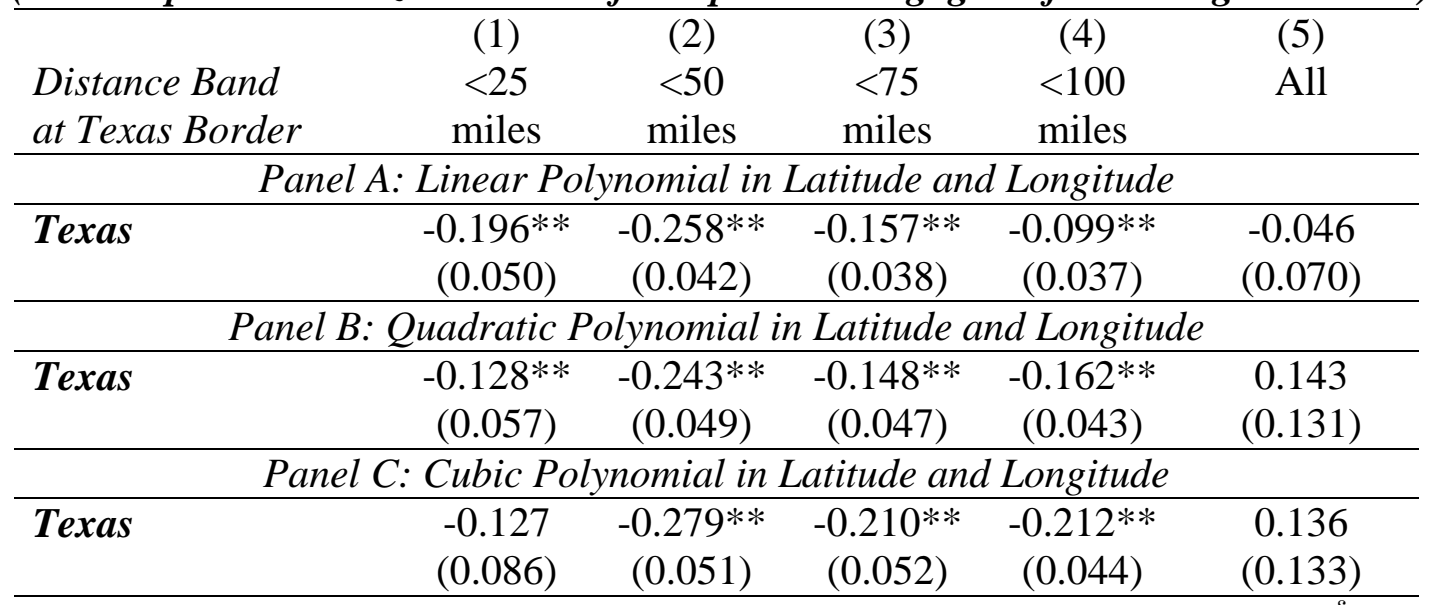

Panel D: Polynomial in Latitude and Longitude using post-double-LASSO ${ }^{\S}$

\begin{tabular}{lccccc}
\hline Texas & -0.103 & $-0.252^{* *}$ & $-0.208^{* *}$ & $-0.207 * *$ & 0.198 \\
& $(0.068)$ & $(0.051)$ & $(0.053)$ & $(0.045)$ & $(0.161)$ \\
\hline LASSO Selected & $X, Y, Y^{2}$, & $X, Y, X^{2}$, & $X, Y, X^{2}$, & $X, Y$, & $X, Y, X^{2}$, \\
Polynomial Terms & $Y^{3}, X^{2} Y$, & $Y^{3}, X^{2} Y$, & $Y^{2}, X Y$, & $Y^{2}, X Y$, & $Y^{2}, X Y$, \\
& $Y^{4}, X Y^{3}$ & $X Y^{3}, X^{3} Y$ & $Y^{3}, X^{2} Y$, & $X^{3}, X^{2} Y$, & $X^{2} Y$, \\
& & & $X Y^{2}, X^{2} Y^{2}$ & $X Y^{2}, X^{2} Y^{2}$, & $X Y^{2}, Y^{4}, X Y^{3}$, \\
& & &,$X^{3} Y$ & $X^{3} Y$ & $X^{2} Y^{2}$ \\
\hline Observations & 782769 & 2038693 & 5103812 & 8697085 & 14919360 \\
\hline Other Covariates & Yes & Yes & Yes & Yes & Yes \\
\hline Year Effects & Yes & Yes & Yes & Yes & Yes \\
\hline Month Effects & Yes & Yes & Yes & Yes & Yes \\
\hline Origin Year Effects & Yes & Yes & Yes & Yes & Yes \\
\hline Border FE & Yes & Yes & Yes & Yes & Yes
\end{tabular}

*Significant at $10 \%$ level; **Significant at $5 \%$ level. Robust standard errors clustered by county in parenthesis. Results presented are from Cox proportional hazard model of nonprime mortgage default rates on the Texas dummy and multidimensional RD polynomial in latitude and longitude. Loans were followed up from origination to either default or non-default until the end of the sample period in 12/2011 for a maximum period of 153 months. All non-defaulting loans were treated as right-censored. The survival data is single spell with right-censoring. Other non-time varying covariates are: initial FICO score, dummy for initial CLTV was 80 percent or higher, dummy for adjustable rate mortgage, dummy for cash-out refinance, state border-segment fixed effects. Time-varying covariates are 1quarter lagged log house price change (Lagged $\Delta \mathrm{HPI}$ ), county unemployment rate, log of county-level median household income, average county-level mortgage denial rate between 2000 and 2006, year and month effects, and origination year effects. The coefficient on the Texas dummy should be interpreted as percent difference in mortgage default hazard on Texas side of the border vis-a-vis NM, $\mathrm{OK}$, AR, and LA side of the border. Data on nonprime mortgage defaults are from ABS database from CoreLogic. ${ }^{\S}$ Selection of multidimensional RD polynomial terms is based on simple linear regressions. The LASSO-selected terms then were used in hazard model regressions. See Appendix C for other details on LASSO selection procedure. 


\section{Do Restrictions on Home Equity Extraction Contribute to Lower Mortgage Defaults? Evidence from a Policy Discontinuity at the Texas Border}

\section{Anil Kumar}

\section{Online Appendix}

\section{Appendix A: Additional Robustness Tests \\ Informal test of precise manipulation of location around the Texas border}

A crucial identification assumption for RD validity is that individuals with a strong taste for mortgage borrowing do not precisely manipulate their location around the discontinuity threshold (the Texas border). As discussed earlier, the 1997 constitutional amendment in Texas significantly relaxed home equity borrowing restrictions by opening the door for homeowners to tap into their home equity through second mortgages or cash-out refinancing, subject to an 80 percent cap on CLTV. If individuals move in response to restrictions on home equity borrowing, then the 1997 amendment should lead to increased net outflow from neighboring states to Texas, relative to net outflows to the states other than Texas. I use IRS data on state-to-state migration of tax returns to present tentative evidence that borrowers did not manipulate their location in response to the 1997 amendment that eased access to home equity.

Table A2 shows that from 1993 to 1996, before the 1997 amendment, net outflow of tax returns from neighboring states to Texas was 0.08 percent of all non-migrant returns in these states. The outflows increased by 0.12 percentage points to 0.20 percent after the law change. On the other hand, net outflows to other states increased by an even larger amount-0.50 percentage points. This casts doubt on the hypothesis that ease of obtaining credit against home equity in Texas may have been associated with increased net migration from neighboring states to Texas. ${ }^{23}$

\section{Additional robustness checks for county-level estimates}

Tables A3 through A7 examine robustness of county-level estimates to additional covariates, an alternative estimation sample, and nonparametric estimation methods. To get a sense of the extent to which the Texas policy may have lowered incidence of underwater mortgages, Table A3 reports linear RD regressions of share of mortgages underwater by 20 percent or more. Table A4 reports multidimensional RD estimates similar to Table 4 for nonprime mortgages but

\footnotetext{
${ }^{23}$ A more elaborate difference-in-differences specification controlling for other interstate differences in characteristics also reveals no significant difference in net outflow into Texas relative to other states before vs. after the 1997 law change that eased borrowing against home equity. Results are available on request from the author.
} 
additionally controls for state-specific policy differences: whether the state requires judicial foreclosure and whether the state allows redemption. To account for any remaining differences in state-level policy that affect housing supply, I also control for house price elasticity from Saiz (2010). ${ }^{24}$ The estimates are statistically similar but larger in magnitude than those in Table 4. Table A5 presents traditional RD estimates using nonparametric methods in Calonico et al. (2014a, 2014b) for the data-driven MSE-Optimal bandwidth without covariates (column 1) and with covariates (column 2).

Identification of the treatment effect using cross-border comparisons between Texas and neighboring states can be further improved by restricting the estimation sample to just contiguous border counties (Dube et al., 2010). In this case, estimation is based on stacked data consisting of all possible contiguous county pairs. In addition to other covariates used in previous county-level specifications, we can now include county-pair fixed effects. An added advantage is that contiguous counties just outside the Texas border are plausibly better controls for Texas' counties, obviating the need to use RD specifications. Confirming this expectation, Table A6 shows that the estimated impact of the Texas policy on nonprime mortgage default rates is strikingly similar across specifications without the RD polynomial in column (1) and with post-double LASSO selected RD polynomial specifications in columns (2) and (3). To keep the model simple, regressions in Table A6 control for a parsimonious set of baseline covariates similar to Table 2. Table A7 reports RD estimates of the effect of the Texas policy on mortgage default rates for even smaller distance bands on either side of the Texas border. Table A8 explores the extent of discontinuity in other covariates for the 10-mile bandwidth and for the MSE-Optimal bandwidths. Finally, Table A9 in Appendix A compares the covariate-adjusted multidimensional RD estimates reported in Tables 3 and 4 with those without covariates and presents identified sets using formulas derived in Oster (2017).

\footnotetext{
${ }^{24}$ The standard errors in Table A2 should be viewed as a lower bound as estimates have been clustered at the county level and not at the state level. The correct approach would be to cluster standard errors at the state-level house prices (Cameron and Miller, 2013; Cameron et al., 2011; Donald and Lang, 2007; Wooldridge, 2003). However, this is infeasible because the number of clusters (states) is just 5 .
} 
Table A1: Impact of Texas Home Equity Regulation on Serious Mortgage Delinquency using State Level Data from 2007-2011

\begin{tabular}{lcccc}
\hline & $(1)$ & $(2)$ & $(3)$ & $(4)$ \\
& Prime & Prime & SubPrime & SubPrime \\
\hline Texas & $-0.988^{* *}$ & $-0.555^{* *}$ & $-3.594^{* *}$ & $-1.768^{* *}$ \\
& $(0.218)$ & $(0.249)$ & $(0.875)$ & $(0.641)$ \\
Initial FICO & & & & \\
& -0.017 & -0.015 & -0.024 & -0.033 \\
& $(0.013)$ & $(0.011)$ & $(0.055)$ & $(0.042)$ \\
Lagged House Price Growth & $-0.069^{* *}$ & $-0.067^{* *}$ & $-0.210^{* *}$ & $-0.191^{* *}$ \\
& $(0.016)$ & $(0.015)$ & $(0.037)$ & $(0.024)$ \\
Unemployment Rate & & & & \\
& $0.547^{* *}$ & $0.535^{* *}$ & $1.497^{* *}$ & $1.601^{* *}$ \\
Log Median Household Income & $(0.082)$ & $(0.086)$ & $(0.238)$ & $(0.178)$ \\
& 0.764 & 0.230 & 6.969 & $8.716^{* *}$ \\
Judicial & $(1.041)$ & $(1.436)$ & $(5.505)$ & $(3.627)$ \\
& & & & $4.505^{* *}$ \\
Redemption & & $0.869^{* *}$ & & $(0.813)$ \\
& & $(0.356)$ & & -0.213 \\
Housing Elasticity & & -0.112 & & $(1.004)$ \\
& & $(0.232)$ & & -0.614 \\
Observations & & -0.259 & & $(0.422)$ \\
\hline R-Sq & & $(0.199)$ & & 245 \\
\hline Nation & 255 & 245 & 255 & 0.78 \\
\hline
\end{tabular}

Note: Standard errors clustered by state are reported in parenthesis. Estimates are based on simple linear regression of state-level subprime default rate from 2007 to 2011 on a Texas dummy and other state level covariates listed in the table. Estimates are weighted by state employment. Sources: MBA data on delinquencies from Haver analytics; house price growth from FHFA; unemployment rate and median household income from BLS/LAUS; initial FICO based on statelevel average from ABS data from RADAR data warehouse. See the data section on page 8 for sources of data on other covariates. 
Table A2: Migration of Tax Returns from/to Neighboring States (AR, LA, NM, and OK) 3 Years Before and After 1997 Law Relaxing Mortgage Borrowing Restrictions (All outflows and inflows measured as percent of non-migrant returns)

\begin{tabular}{lccc}
\hline & $(1)$ & $(2)$ & $(3)$ \\
\hline & $\begin{array}{c}\text { Before 1997 } \\
(1993-1996)\end{array}$ & $\begin{array}{c}\text { After 1997 } \\
(1998-2001)\end{array}$ & $\begin{array}{c}\text { After minus } \\
\text { Before }\end{array}$ \\
\hline A. Outflow & & & $\mathbf{0 . 0 4}$ \\
\hline To Texas & 0.87 & 0.91 & $\mathbf{0 . 0 3}$ \\
To Other States & 2.72 & 2.75 & $\mathbf{0 . 0 1}$ \\
Texas minus Other States & $\mathbf{- 1 . 8 5}$ & $\mathbf{- 1 . 8 4}$ & $\mathbf{- 0 . 0 8}$ \\
\hline B. Inflow & 0.79 & 0.71 & $\mathbf{- 0 . 4 7}$ \\
\hline $\begin{array}{l}\text { From Texas } \\
\text { From Other States }\end{array}$ & 2.98 & 2.51 & $\mathbf{0 . 3 9}$ \\
$\begin{array}{l}\text { Texas minus Other States } \\
\text { C. } \text { Net Migration (Outflow-Inflow) }\end{array}$ & $\mathbf{- 2 . 1 9}$ & $\mathbf{- 1 . 8 0}$ & $\mathbf{0 . 1 2}$ \\
\hline To Texas & 0.08 & 0.20 & $\mathbf{0 . 5 0}$ \\
$\begin{array}{l}\text { To Other States } \\
\text { Texas minus Other States }\end{array}$ & -0.26 & 0.24 & $\mathbf{- 0 . 3 8}$ \\
\hline $\begin{array}{l}\text { Note: This table is based on state level IRS data on state-to-state migration of tax returns calculated } \\
\text { using online tools at taxfoundation.org. }\end{array}$ & &
\end{tabular}


Table A3: Linear RD Regressions of Share of Mortgages Underwater by 20 Percent or More

\begin{tabular}{lccccc}
\hline & $(1)$ & $(2)$ & $(3)$ & $(4)$ & $(5)$ \\
& $<25$ miles & $<50$ miles & $<75$ miles & $<100$ miles & All \\
\hline Texas & -6.715 & $-10.161^{*}$ & $-15.771^{* *}$ & $-12.177^{* *}$ & 1.629 \\
& $(12.580)$ & $(5.034)$ & $(4.061)$ & $(3.122)$ & $(2.129)$ \\
Year Effects & Yes & Yes & Yes & Yes & Yes \\
& & & & & \\
Linear Polynomial in Distance & Yes & Yes & Yes & Yes & Yes \\
& & & & & \\
Other Covariates & Yes & Yes & Yes & Yes & Yes \\
\hline Observations & 73 & 139 & 246 & 351 & 898 \\
N_counties & 17.00 & 32.00 & 57.00 & 83.00 & 204.00 \\
R-Sq & 0.31 & 0.12 & 0.29 & 0.34 & 0.20 \\
\hline
\end{tabular}

*Significant at $10 \%$ level; ${ }^{* *}$ Significant at $5 \%$ level. Robust standard errors clustered by county are in parenthesis. Results presented are from linear regression of share of mortgages underwater by 20 percent or more at county-year level from 2007 to 2011 on the Texas dummy, a linear RD polynomial in minimum distance to the Texas border (normalized to zero at the border), and other county-level baseline covariates: county unemployment rate, 1-year lagged log house price change (Lagged $\Delta$ HPI), county-level initial FICO score, and year effects. Estimates weighted by number of loans in each county-year cell. Data from Holmes (1998) was used to get distances of county centroid to the Texas border with respective states. Results are based on data on nonprime mortgages from ABS database and CoreLogic TrueLTV database available from RADAR data warehouse. 
Table A4: Robustness of Multidimensional RD to Controlling for State Level Policy Variables

(Dependent Variable: County-Level Default Rate)

(Data: ABS Data on Nonprime Mortgages Grouped to County Level)

\begin{tabular}{|c|c|c|c|c|c|}
\hline & (1) & (2) & (3) & (4) & $(5)$ \\
\hline Distance Band & $<25$ & $<50$ & $<75$ & $<100$ & All \\
\hline at Texas Border & miles & miles & miles & miles & \\
\hline \multicolumn{6}{|c|}{ Panel A: Linear Polynomial in Latitude and Longitude } \\
\hline \multirow[t]{2}{*}{ Texas } & $-7.378 * *$ & $-5.336 * *$ & $-3.313 *$ & -2.022 & $-3.087 * *$ \\
\hline & $(2.315)$ & $(1.620)$ & $(1.768)$ & $(1.424)$ & $(1.249)$ \\
\hline \multicolumn{6}{|c|}{ Panel B: Quadratic Polynomial in Latitude and Longitude } \\
\hline \multirow[t]{2}{*}{ Texas } & $-7.454 * *$ & $-5.214 * *$ & $-3.600 * *$ & -2.303 & $-4.666 * *$ \\
\hline & $(2.272)$ & $(1.648)$ & $(1.589)$ & $(1.413)$ & $(1.364)$ \\
\hline \multicolumn{6}{|c|}{ Panel C: Cubic Polynomial in Latitude and Longitude } \\
\hline \multirow[t]{2}{*}{ Texas } & $-10.987 * *$ & $-8.035 * *$ & $-4.377 * *$ & $-4.034 *$ & $-6.068 * *$ \\
\hline & $(2.062)$ & $(1.836)$ & $(2.179)$ & $(2.202)$ & $(1.381)$ \\
\hline \multicolumn{6}{|c|}{ Panel D: Polynomial in Latitude and Longitude using post-double-LASSO ${ }^{\S}$} \\
\hline \multirow[t]{2}{*}{ Texas } & $-6.465 * *$ & $-4.806 * *$ & $-3.878 * *$ & $-2.476^{*}$ & $-3.087 * *$ \\
\hline & $(2.003)$ & $(1.499)$ & $(1.593)$ & $(1.331)$ & $(1.249)$ \\
\hline LASSO Selected & None & None & None & None & $X, Y$ \\
\hline \multirow{2}{*}{$\begin{array}{l}\text { Polynomial } \\
\text { Terms }\end{array}$} & & & & & \\
\hline & & & & & \\
\hline Observations & 310 & 569 & 829 & 1073 & 2252 \\
\hline Counties & 64 & 117 & 170 & 219 & 456 \\
\hline R-Square & 0.8939 & 0.8900 & 0.8988 & 0.9061 & 0.8597 \\
\hline \multirow{2}{*}{$\begin{array}{l}\text { Other Covariates } \\
\text { State Policy Vars }\end{array}$} & Yes & Yes & Yes & Yes & Yes \\
\hline & Yes & Yes & Yes & Yes & Yes \\
\hline \multirow{2}{*}{$\begin{array}{l}\text { Year Effects } \\
\text { Bordor FF }\end{array}$} & Yes & Yes & Yes & Yes & Yes \\
\hline & Yes & Yes & Yes & Yes & Yes \\
\hline
\end{tabular}

*Significant at $10 \%$ level; **Significant at 5\% level. Robust standard errors clustered by county in parenthesis. The dependent variable mortgage default is defined as share of mortgages 90 -plus days delinquent or in foreclosure or REO. Results presented are from linear regression of countyyear level mortgage default rates from 2007 to 2011 on the Texas dummy and multidimensional $\mathrm{RD}$ polynomial in latitude and longitude. Other county-level baseline covariates included are the county unemployment rate, 1-year lagged log house price change (Lagged $\Delta \mathrm{HPI}$ ), county-level initial FICO score, share of mortgages with initial CLTV 80 percent or higher, county-level log median household income, share of adjustable rate mortgages, share of cash-out refinance mortgages, and average county-level mortgage denial rate between 2000 and 2006, year effects, and state border-segment fixed effects. Estimates weighted by number of loans in each countyyear cell. The coefficient on the Texas dummy should be interpreted as the discontinuity in mortgage default rate on Texas side of the border vis-a-vis NM, OK, AR, and LA side of the border. Data from Holmes (1998) was used to get distances of county centroid to the Texas border with respective states. Data on county-level nonprime default rates and other mortgage characteristics are from ABS database on nonprime mortgages from CoreLogic. ${ }^{\S}$ See Appendix $\mathrm{C}$ for details on LASSO selection procedure. State-specific policy variables included are dummies for judicial foreclosure, whether the state allows redemption, and state-level house price elasticity. 
Table A5: Conventional, Robust and Bias-Corrected Regression Discontinuity Estimates at Datadriven Mean Squared Error (MSE)-Optimal Bandwidth Choices (Dependent Variable: County-Level Nonprime Mortgage Default Rate)

(1)

Without Covariates Covariate-Adjusted

\begin{tabular}{|c|c|c|}
\hline Conventional & $\begin{array}{c}-5.129 * * \\
(1.726)\end{array}$ & $\begin{array}{c}5.604^{* *} \\
(1.299)\end{array}$ \\
\hline Bias-corrected & $\begin{array}{c}-6.165^{* *} \\
(1.726)\end{array}$ & $\begin{array}{c}-5.530 * * \\
(1.299)\end{array}$ \\
\hline Robust & $\begin{array}{c}-6.165^{* *} \\
(1.951)\end{array}$ & $\begin{array}{c}-5.530 * * \\
(1.881)\end{array}$ \\
\hline Kernel & Triangular & Triangular \\
\hline RD Polynomial & Local Linear & Local Linear \\
\hline MSE-Optimal Bandwidth & 117.357 & 78.115 \\
\hline $\mathrm{N}$ & 2252 & 2252 \\
\hline Effective N (left of cutoff) & 602 & 377 \\
\hline Effective N (right of cutoff) & 611 & 481 \\
\hline
\end{tabular}

*Significant at $10 \%$ level; **Significant at $5 \%$ level. All calculations are based on countylevel ABS data from 2007 to 2011. Estimates based on "rdrobust" software described in Calonico et al. (2014a, 2014b) and Calonico et. al (2017). MSE-Optimal bandwidth based on the implementation in Calonico et al. (2014a) of the simple plug-in bandwidth proposed in Imbens and Kalyanaraman (2012). Estimates in column (2) adjusted for year dummies and the following covariates: initial FICO, lagged house price change, mortgage denial rate, share of borrowers with initial CLTV 80 percent or higher, share of ARMs, unemployment rate, and median household income. 
Table A6: Results Using Contiguous Border Counties Sample

(Dependent Variable: County-Level Default Rate)

(Data: ABS Data on Nonprime Mortgages Grouped to County Level)

\begin{tabular}{|c|c|c|c|}
\hline & $\begin{array}{c}(1) \\
\text { OLS }\end{array}$ & $\begin{array}{c}(2) \\
\text { LASSO }\end{array}$ & $\begin{array}{c}(3) \\
\text { LASSO }\end{array}$ \\
\hline Texas & $\begin{array}{c}-3.735^{* *} \\
(0.718)\end{array}$ & $\begin{array}{c}-3.346 * * \\
(0.730)\end{array}$ & $\begin{array}{c}-3.012 * * \\
(1.297)\end{array}$ \\
\hline Multidimensional RD & No & Yes & No \\
\hline Traditional RD & No & No & Yes \\
\hline Other Covariates & Yes & Yes & Yes \\
\hline County Pair Effects & Yes & Yes & Yes \\
\hline Year Effects & Yes & Yes & Yes \\
\hline$N$ & 637 & 637 & 637 \\
\hline N_counties & 76 & 69 & 69 \\
\hline $\mathrm{R}-\mathrm{Sq}$ & 0.9460 & 0.9461 & 0.9460 \\
\hline \multicolumn{4}{|c|}{$\begin{array}{l}\text { *Significant at } 10 \% \text { level; **Significant at } 5 \% \text { level. Robust standard errors clustered by county } \\
\text { in parenthesis. The dependent variable mortgage default is defined as share of mortgages } 90 \text {-plus } \\
\text { days delinquent or in foreclosure or REO. Results presented are from linear regression of county- } \\
\text { year level mortgage default rates from } 2007 \text { to } 2011 \text { on the Texas dummy and a linear RD } \\
\text { polynomial in minimum distance to the Texas border (normalized to zero at the border). Other } \\
\text { county-level baseline covariates included are the county unemployment rate, 1-year lagged log } \\
\text { house price change (Lagged } \Delta \mathrm{HPI} \text { ), county-level initial FICO score, county-pair fixed effects, year } \\
\text { effects. Estimation sample was restricted to contiguous border counties. Estimates weighted by } \\
\text { number of loans in each county-year cell. The coefficient on the Texas dummy should be } \\
\text { interpreted as the discontinuity in mortgage default rate on Texas side of the border vis-a-vis NM, } \\
\text { OK, AR, and LA side of the border. County-level nonprime mortgage default rates are based on } \\
\text { ABS database from RADAR data warehouse. }\end{array}$} \\
\hline
\end{tabular}


Table A7: RD Estimates of the Effect of the Texas Policy for Smaller Distance Bands on Either Side of the Texas Border (Dependent Variable: County-Level Default Rate)
(1)
(2)
(3)
(4)
(5)
(6)
$<10$ miles $<10$ miles $<15$ miles $<15$ miles $<20$ miles $<20$ miles

\begin{tabular}{|c|c|c|c|c|c|c|}
\hline \multicolumn{7}{|c|}{ Panel A: All Mortgages } \\
\hline Texas & $-3.799 * *$ & $-4.714 * *$ & $-1.795 * *$ & $-2.282 * *$ & $-2.086^{*}$ & $-2.328 *$ \\
\hline & $(1.158)$ & $(1.720)$ & $(0.823)$ & $(0.955)$ & $(1.180)$ & (1.195) \\
\hline Observations & 72 & 72 & 184 & 184 & 280 & 280 \\
\hline N_counties & 15.00 & 15.00 & 38.00 & 38.00 & 58.00 & 58.00 \\
\hline $\mathrm{R}-\mathrm{Sq}$ & 0.89 & 0.90 & 0.74 & 0.75 & 0.55 & 0.63 \\
\hline \multicolumn{7}{|c|}{ Panel B: Nonprime Mortgages } \\
\hline Texas & $\begin{array}{c}-11.031^{* *} \\
(2.131) \\
\end{array}$ & $\begin{array}{c}-10.317^{* *} \\
(2.014) \\
\end{array}$ & $\begin{array}{c}-5.932 * * \\
(2.463) \\
\end{array}$ & $\begin{array}{l}-3.479 \\
(2.184) \\
\end{array}$ & $\begin{array}{c}-6.536 * * \\
(3.207) \\
\end{array}$ & $\begin{array}{l}-2.899 \\
(2.266) \\
\end{array}$ \\
\hline Observations & 72 & 72 & 184 & 184 & 280 & 280 \\
\hline N_counties & 15.00 & 15.00 & 38.00 & 38.00 & 58.00 & 58.00 \\
\hline $\mathrm{R}-\mathrm{Sq}$ & 0.89 & 0.94 & 0.80 & 0.83 & 0.70 & 0.75 \\
\hline Linear in Distance & Yes & Yes & Yes & Yes & Yes & Yes \\
\hline Year Effects & Yes & Yes & Yes & Yes & Yes & Yes \\
\hline Baseline Covariates & No & Yes & No & Yes & No & Yes \\
\hline
\end{tabular}

*Significant at $10 \%$ level; **Significant at 5\% level. Robust standard errors clustered by county in parenthesis. The dependent variable mortgage default is defined as share of mortgages 90-plus days delinquent or in foreclosure or REO. Results presented are from linear regression of county-year level mortgage default rates from 2007 to 2011 on the Texas dummy and a linear RD polynomial in minimum distance to the Texas border (normalized to zero at the border). Other county-level baseline covariates included are the county unemployment rate, 1-year lagged log house price change (Lagged $\Delta \mathrm{HPI}$ ), county-level initial FICO score, and year effects. Estimates weighted by number of loans in each county-year cell. The coefficient on the Texas dummy should be interpreted as the discontinuity in mortgage default rate on Texas side of the border vis-a-vis NM, OK, AR, and LA side of the border. Data from (Holmes, 1998) was used to get distances of county centroid to the Texas border with respective states. Results in Panel A are based on data on all residential mortgages from McDash/Lender Processing Services (LPS) and Panel B on data on nonprime mortgages from ABS database. 
Table A8: Estimated Regression Discontinuity in Covariates

\begin{tabular}{ccccccccc}
\hline$(1)$ & $(2)$ & $(3)$ & $(4)$ & $(5)$ & $(6)$ & $(7)$ & $(8)$ & $(9)$ \\
\hline Initial & Log & Mortgage & Initial- & Debt-to- & Share of & Log & Unemployment & Log \\
FICO & House & Denial & CLTV & Income & ARMs & Appraisal & Rate & Median \\
Score & Price & Rate & 80 & Ratio & & Amount at & Household \\
& Change & & Percent or & & & Loan & Origination \\
& & & & Higher & & & & \\
\hline
\end{tabular}

\section{Panel A: Within 10-Mile Bandwidth}

$\begin{array}{cccccccccc}\text { Texas } & 11.001 & -0.037 & -4.102 & 0.739 & 4.006 & -0.108 & 0.128 & 6.178^{* *} & -0.584 \\ & (21.356) & (0.021) & (5.817) & (3.538) & (2.527) & (0.070) & (0.164) & (1.537) & (0.284)\end{array}$

Panel B: Within Covariate-Adjusted MSE-Optimal 78-Mile Bandwidth ${ }^{\text {\#\# }}$

$\begin{array}{cccccccccc}\text { Texas } & 10.683 & -0.004 & -5.542 & -1.199 & 0.677 & -0.062 * * & 0.216 & 1.541 & 0.259 \\ & (11.725) & (0.012) & (4.878) & (3.821) & (0.411) & (0.021) & (0.217) & (0.862) & (0.295)\end{array}$

Panel C: Within Non-Covariate-Adjusted MSE-Optimal 117-Mile Bandwidth ${ }^{\text {\#\# }}$

\begin{tabular}{cccccccccc} 
Texas & 21.364 & -0.011 & -6.559 & 0.716 & 0.464 & -0.023 & 0.316 & 1.313 & 0.246 \\
& $(11.175)$ & $(0.008)$ & $(4.379)$ & $(3.316)$ & $(0.368)$ & $(0.023)$ & $(0.199)$ & $(0.682)$ & $(0.240)$ \\
\hline
\end{tabular}

Note: **Significant at 5\% level. ${ }^{\# \#}$ MSE-Optimal bandwidth based on the implementation in Calonico et al. (2014a) of the simple plug-in bandwidth proposed in Imbens and Kalyanaraman (2012) (see Table A5). Robust standard errors clustered by county in parenthesis. All calculations are based on county-level data from 2007 to 2011. The table shows RD estimates from a simple regression of the relevant variable—on the Texas dummy and a linear RD polynomial in the running variable (distance from Texas border) and year dummies. All estimates are weighted by county-year level number of nonprime loans. The coefficient on the Texas dummy reported should be interpreted as the discontinuity in the covariate on Texas side of the border vis-a-vis NM, OK, AR, and LA side of the border. Sources of data: county-level initial FICO, initial CLTV, Debt-to-Income (DTI) Ratio, Percent ARM, and Log appriasal amount at origination calculated using ABS data from RADAR data warehouse; county unemployment rate and median household income from BLS/LAUS; county-level house price index from CoreLogic; mortgage denial rates calculated using HMDA data available from the Urban Institute. 
Table A9: Coefficient Stability of Multidimensional RD and Identified Sets Using Oster (2017)

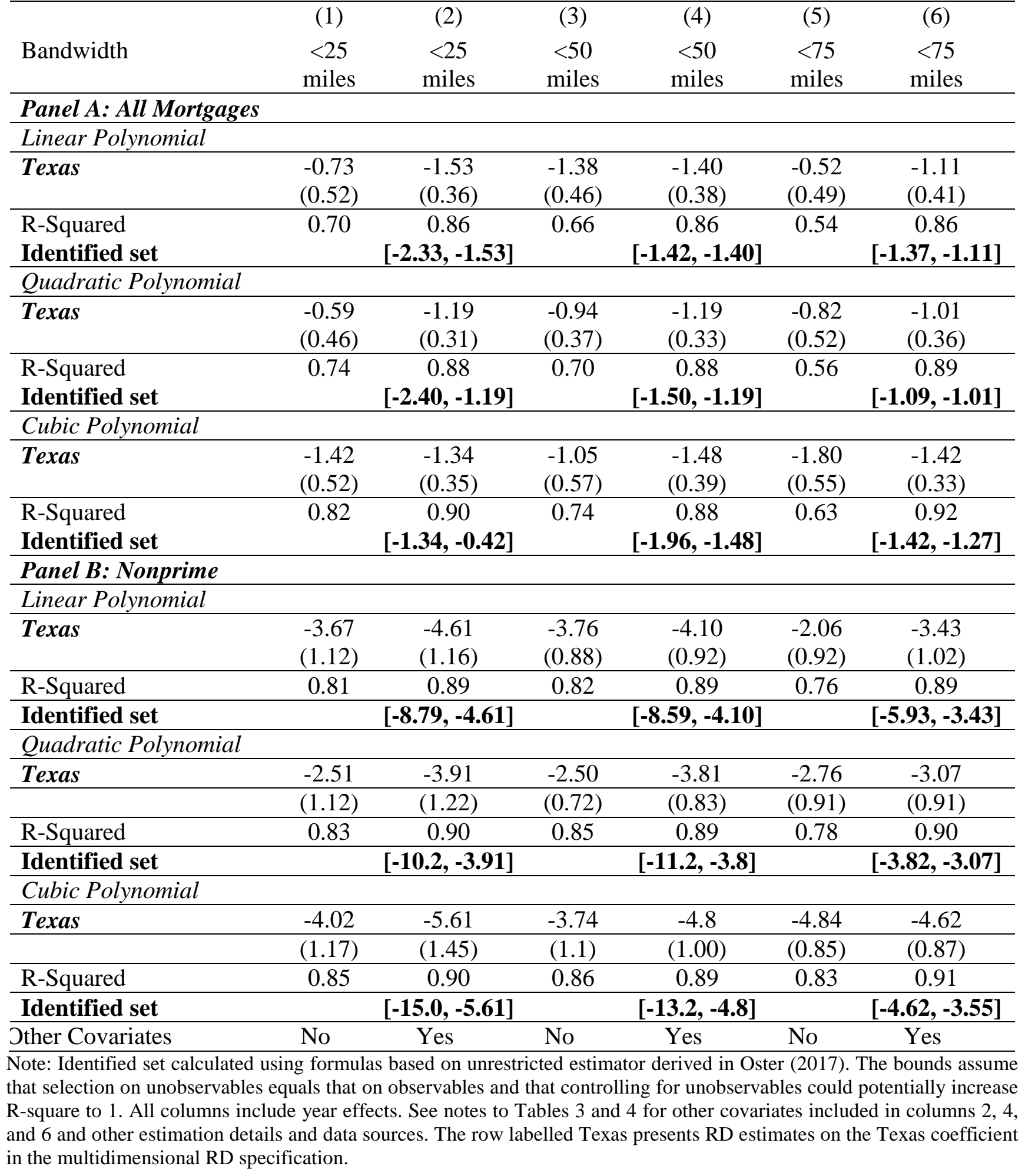




\section{Figure A1}

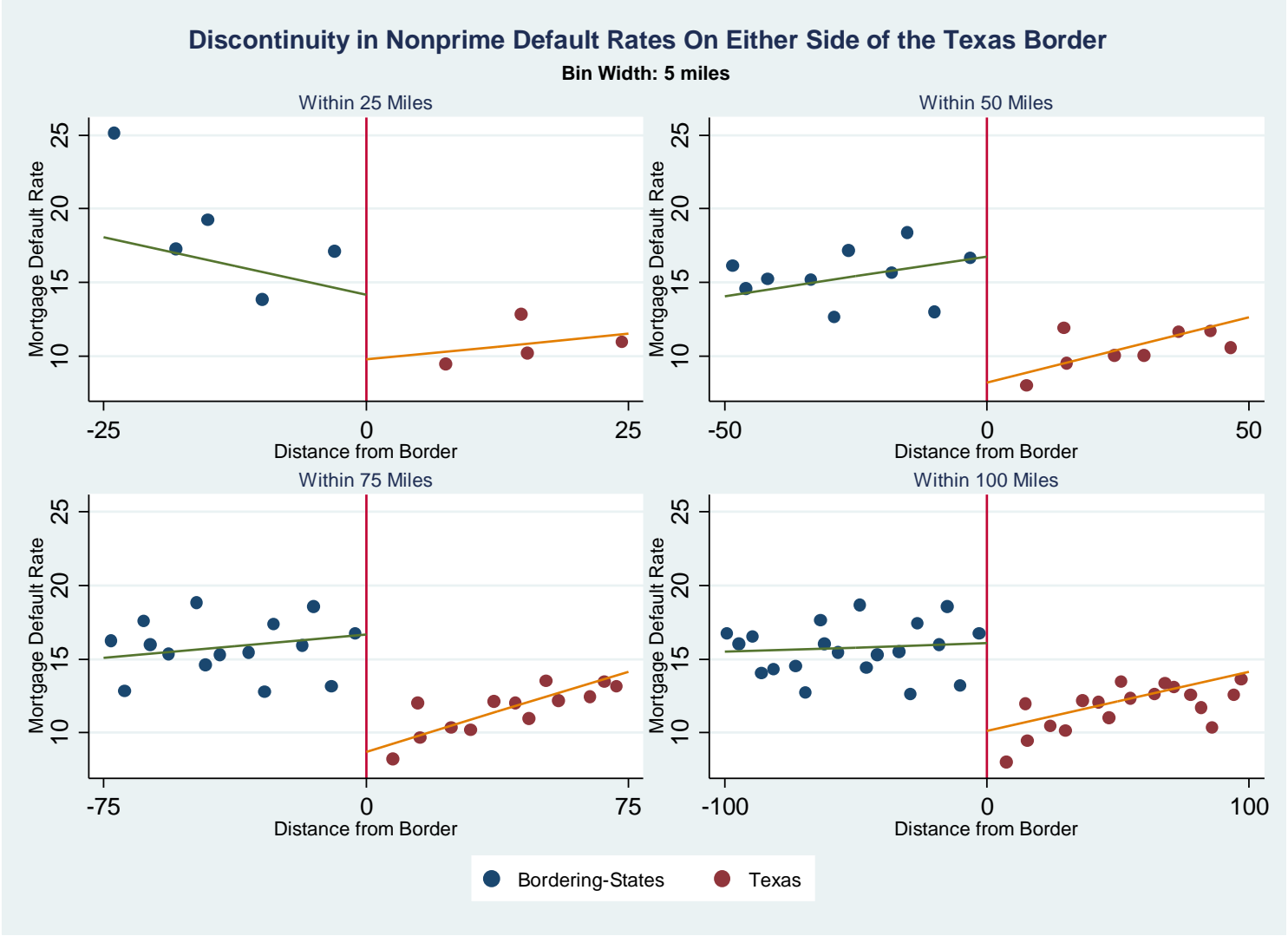

Note: The figure plots the conditional mean of the county-level nonprime mortgage default rate from 2007 to 2011 (controlling for baseline covariates: unemployment, initial FICO, and house price change) within 5-mile wide bins. Linear fitted lines are based on regression of county-level mortgage default rate (residualized by subtracting the prediction from a regression of mortgage default rate on baseline covariates) from 2007 to 2011 on a linear polynomial in distance. Mortgages in default are defined as those 90-plus days delinquent or in foreclosure or real estate owned (REO). All estimates are weighted by county-level number of nonprime loans. Sources of data are: county-level nonprime default rate and initial FICO calculated using ABS data from RADAR data warehouse; county unemployment rate from BLS/LAUS; county-level house price index from CoreLogic. 
Figure A2

Discontinuity in Nonprime Default Rates On Either Side of the Texas Border

Bin Width: 5 miles
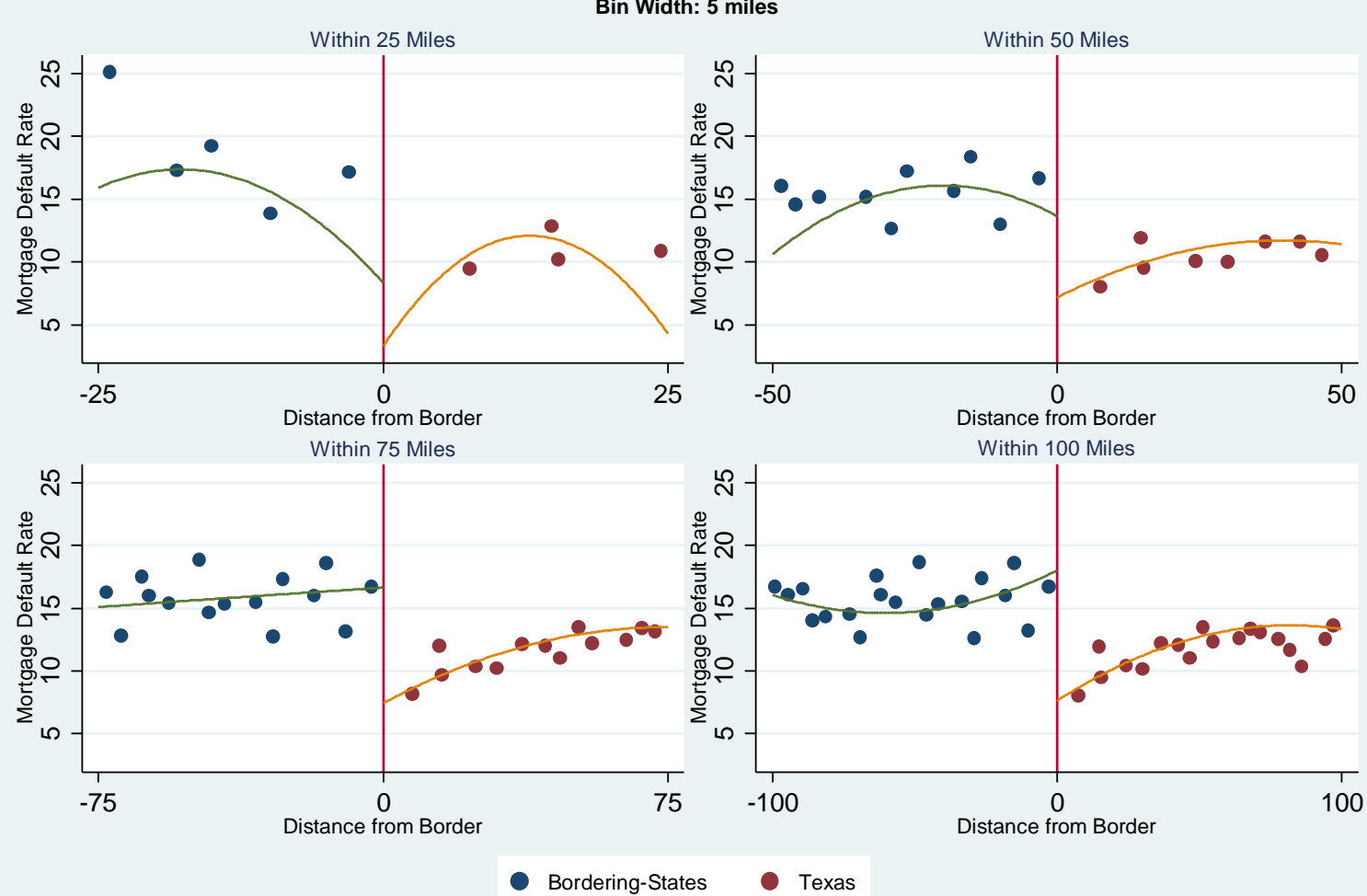

Note: The figure plots conditional mean of county-level nonprime mortgage default rate from 2007 to 2011 (controlling for baseline covariates: unemployment, initial FICO, and house price change) within 5-mile wide bins. Quadratic fitted lines are based on regression of county-level mortgage default rate (residualized by subtracting the prediction from a regression of mortgage default rate on baseline covariates) from 2007 to 2011 on a quadratic polynomial in distance. Mortgages in default are defined as those 90-plus days delinquent or in foreclosure or real estate owned (REO). All estimates are weighted by county-year-level number of nonprime loans. Data sources: county-level nonprime default rate and initial FICO calculated using ABS data from RADAR data warehouse; county unemployment rate from BLS/LAUS; county-level house price index from CoreLogic. 
Figure A3

Discontinuity in Nonprime Default Rates On Either Side of the Texas Border Bin Width: 10 miles
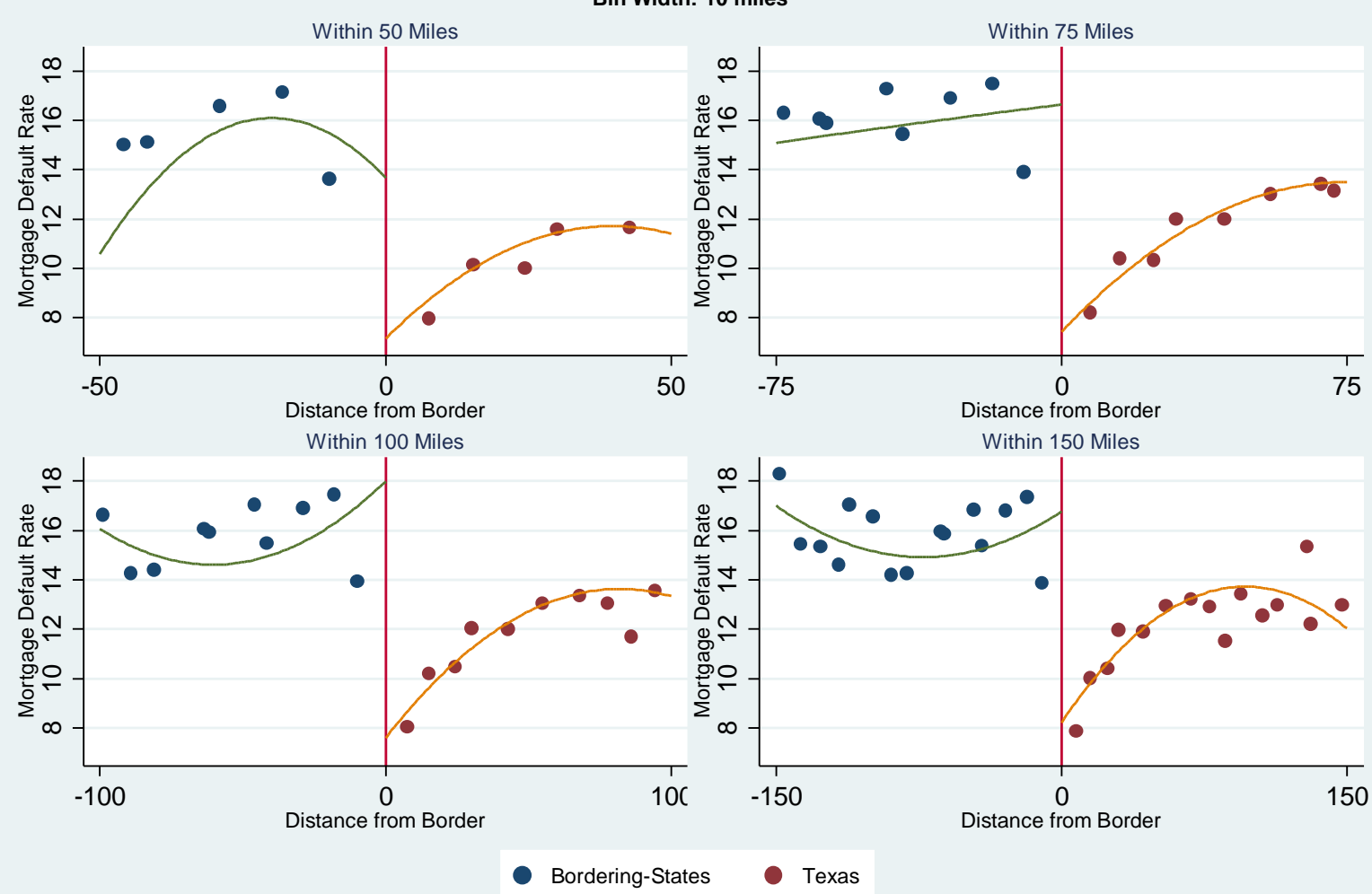

Note: The figure plots conditional mean of county-level nonprime mortgage default rate from 2007 to 2011 (controlling for baseline covariates: unemployment, initial FICO, and house price change) within 10-mile wide bins. Quadratic fitted lines are based on regression of county-level mortgage default rate (residualized by subtracting the prediction from a regression of mortgage default rate on baseline covariates) from 2007 to 2011 on a quadratic polynomial in distance. Mortgages in default are defined as those 90-plus days delinquent or in foreclosure or real estate owned (REO). All estimates are weighted by county-year-level number of nonprime loans. Data sources: county-level nonprime default rate and initial FICO calculated using ABS data from RADAR data warehouse; county unemployment rate from BLS/LAUS; county-level house price index from CoreLogic. 


\section{Figure A4}

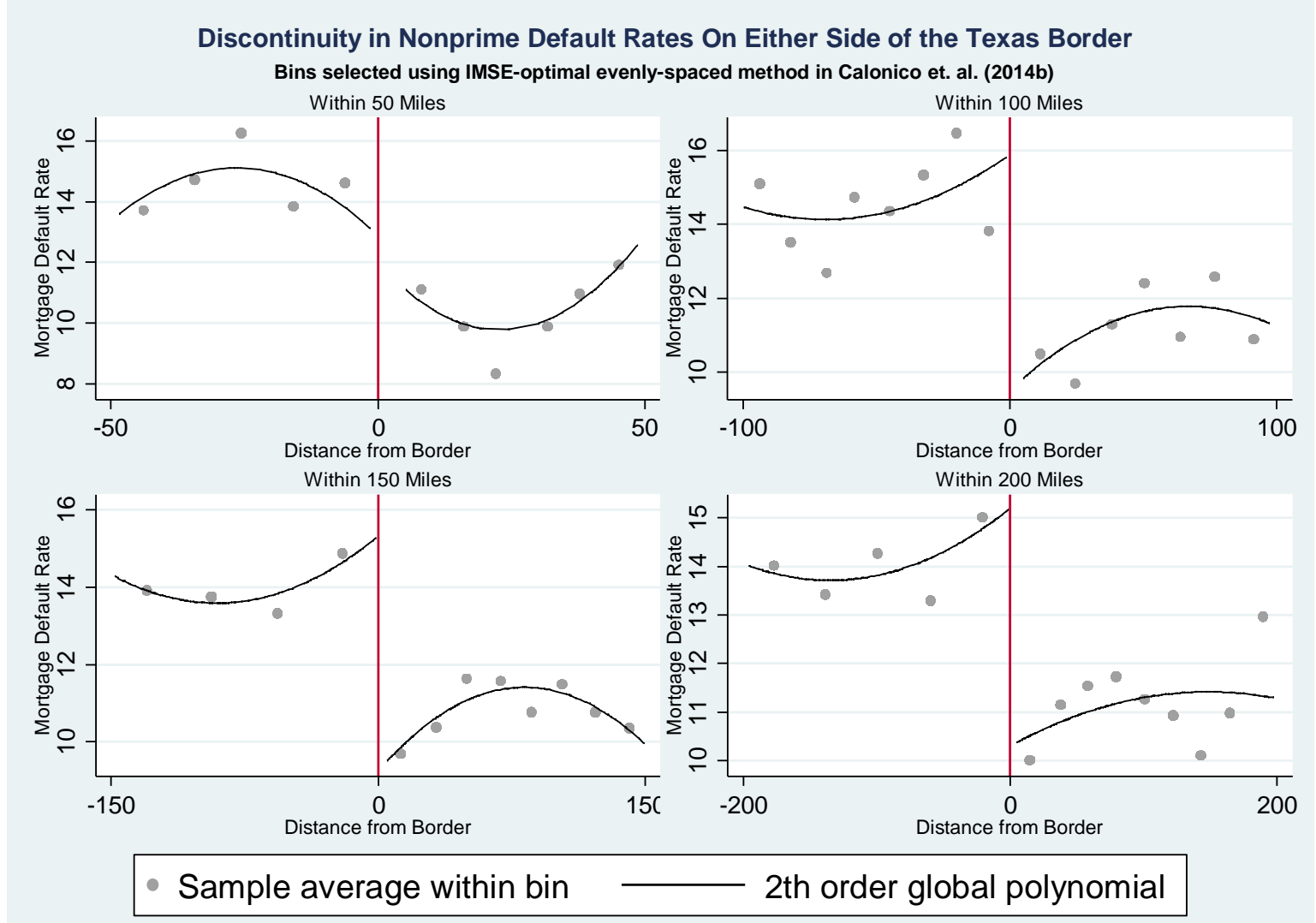

Note: The figure plots binned means of residualized county-level nonprime mortgage default rate from 2007 to 2011 (controlling for unemployment, initial FICO, and house price change) with bins selected using Calonico et al. (2014a, 2015). Quadratic fitted lines are based on regression of county-level mortgage default rate (residualized by subtracting the prediction from a regression of mortgage default rate on baseline covariates) from 2007 to 2011 on a quadratic polynomial in distance. Mortgages in default are defined as those 90-plus days delinquent or in foreclosure or real estate owned (REO). Data sources: county-level nonprime default rate and initial FICO calculated using ABS data from RADAR data warehouse; county unemployment rate from BLS/LAUS; county-level house price index from CoreLogic. 
Figure A5

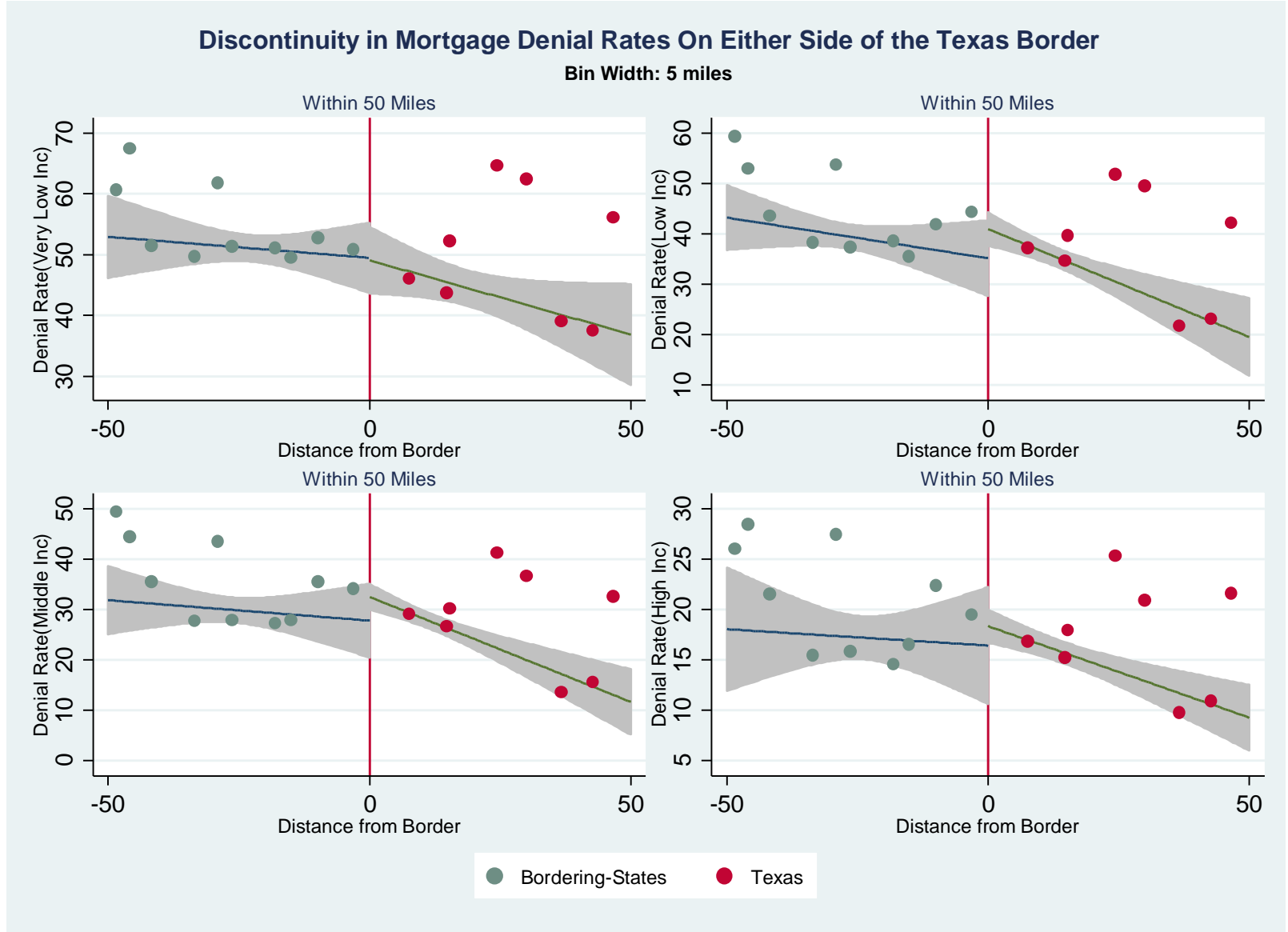

Note: The shaded region is 95 percent confidence intervals of the fitted lines. Scatterplots are of the simple unconditional mean within 5-mile bins of mortgage denial rate by income categories. Linear fitted lines are from a simple regression of the relevant variable on a linear polynomial in distance. All estimates are weighted by countylevel number of nonprime loans. Data sources: mortgage denial rates calculated using HMDA data obtained from the Urban Institute. 
Figure A6

Discontinuity in Share of Cashout Refinance Mortgages On Either Side of the Texas Border Bin Width: 5 miles
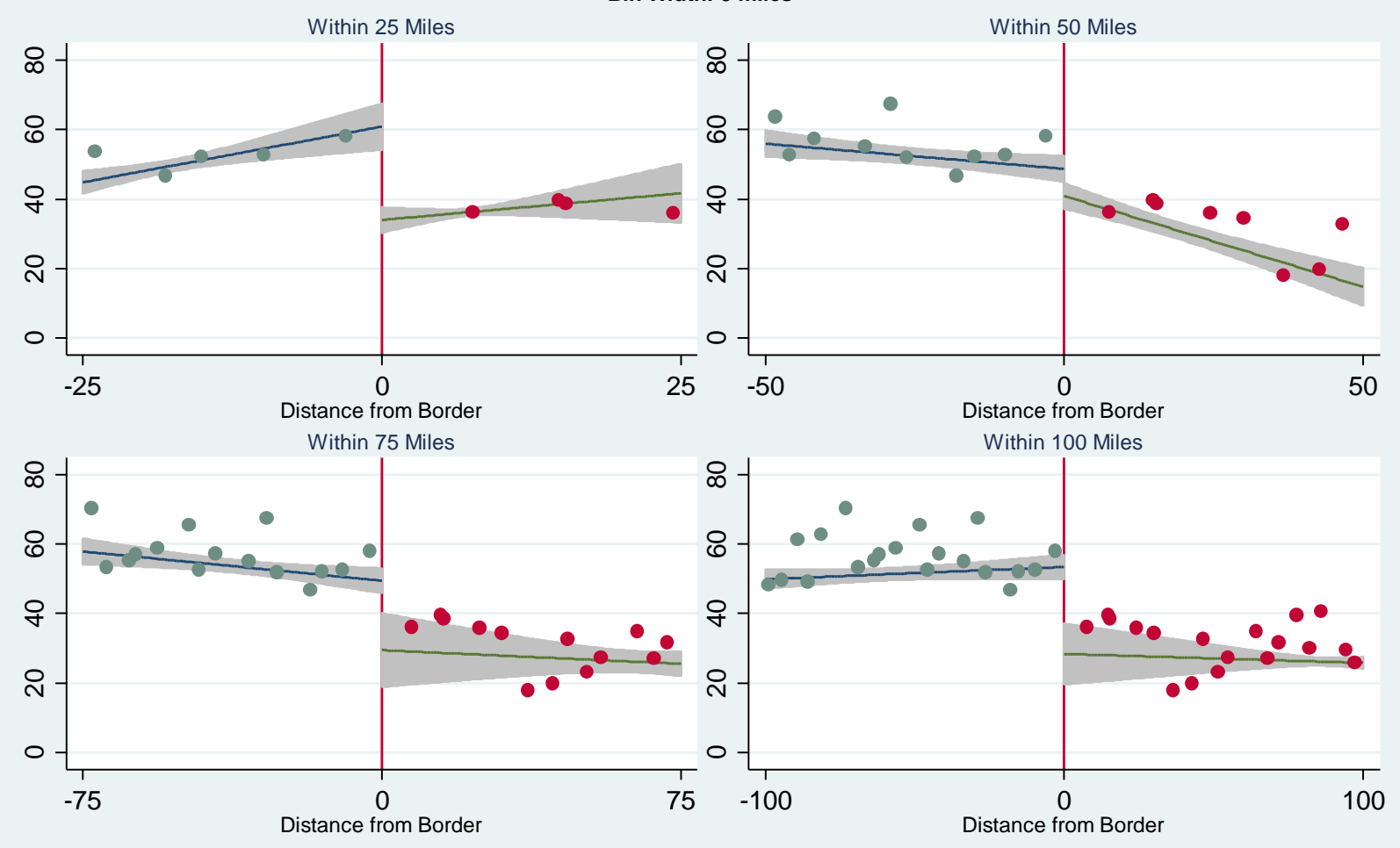

Bordering-States

Texas

Note: The shaded regions are 95 percent confidence intervals of the fitted lines. Scatter plots are of simple unconditional mean within 5-mile bins of county-level share of mortgages used for cash-out refinancing. Linear fitted lines are from a simple regression of the share of cash-out refinances on a linear polynomial in distance. All estimates are weighted by county-year-level number of nonprime loans. Data sources: mortgage denial rates calculated using HMDA data obtained from Urban Institute. 


\section{Placebo tests using other state borders \\ Appendix B: Placebo Tests}

A central argument in the paper has been that cross-border discontinuity in nonprime mortgage default between Texas and the neighboring states exists primarily due to the Texas policy. Accounting for other state-level differences, such a large discontinuity in the nonprime mortgage default rate should not exist around the interstate borders of the remaining 47 contiguous states that allowed unrestricted access to home equity. In other words, the remaining state borders can serve as placebo borders. The estimated cross-border difference around the Texas border should then be in the lower tail of the 48 placebo estimates. The empirical CDF of the coefficient on the Texas treatment dummy can be interpreted as the p-value for the null hypothesis that the coefficient is zero. ${ }^{25}$

Figure B1 shows the empirical CDF of the 48 placebo estimates using just contiguous border county pairs and estimating a simple regression of the nonprime mortgage default rate on the placebo state dummy and a parsimonious set of key county-level covariates: the unemployment rate, Lagged $\triangle H P I$, and initial FICO score. ${ }^{26}$ The Texas coefficient-plotted in the chart as a dashed vertical line- has an empirical CDF of 0.06, suggesting that the cross-border difference around the Texas border is significant at the 6 percent level. To guard against the possibility that this result doesn't just apply to contiguous county pairs, I repeat this analysis for all counties within 50 miles around the borders of the 48 contiguous states for four different RD polynomial specifications in Figure B2: linear and post-double-LASSO selected polynomials in latitude and longitude (left panel) as well as analogous specifications using traditional RD in distance to the state border (right panel). All four specifications yield p-values of well below 10 percent. Overall, the placebo tests presented in Appendix B bolster the conclusion that the Texas policy indeed significantly lowered nonprime mortgage defaults.

\section{Placebo tests based on randomly drawn placebo cutoffs in the estimation sample}

Figure B3 plots the distribution of the estimated discontinuities, for the "covariate index"discussed on page 13 - and the outcome variable, at 100 randomly drawn placebo cutoffs from within the estimation sample, as suggested in Nichols (2007), and shows how they compare with the estimated discontinuity (denoted by the red dashed line) at the actual cutoff — the Texas border.

\footnotetext{
${ }^{25}$ See Chetty, Looney, and Kroft (2009) for a placebo test that is similar in spirit.

${ }^{26}$ A more parsimonious set than those used in Tables 4 and A5 is used due to lack of data on mortgage characteristics for all states.
} 


\section{Figure B1}

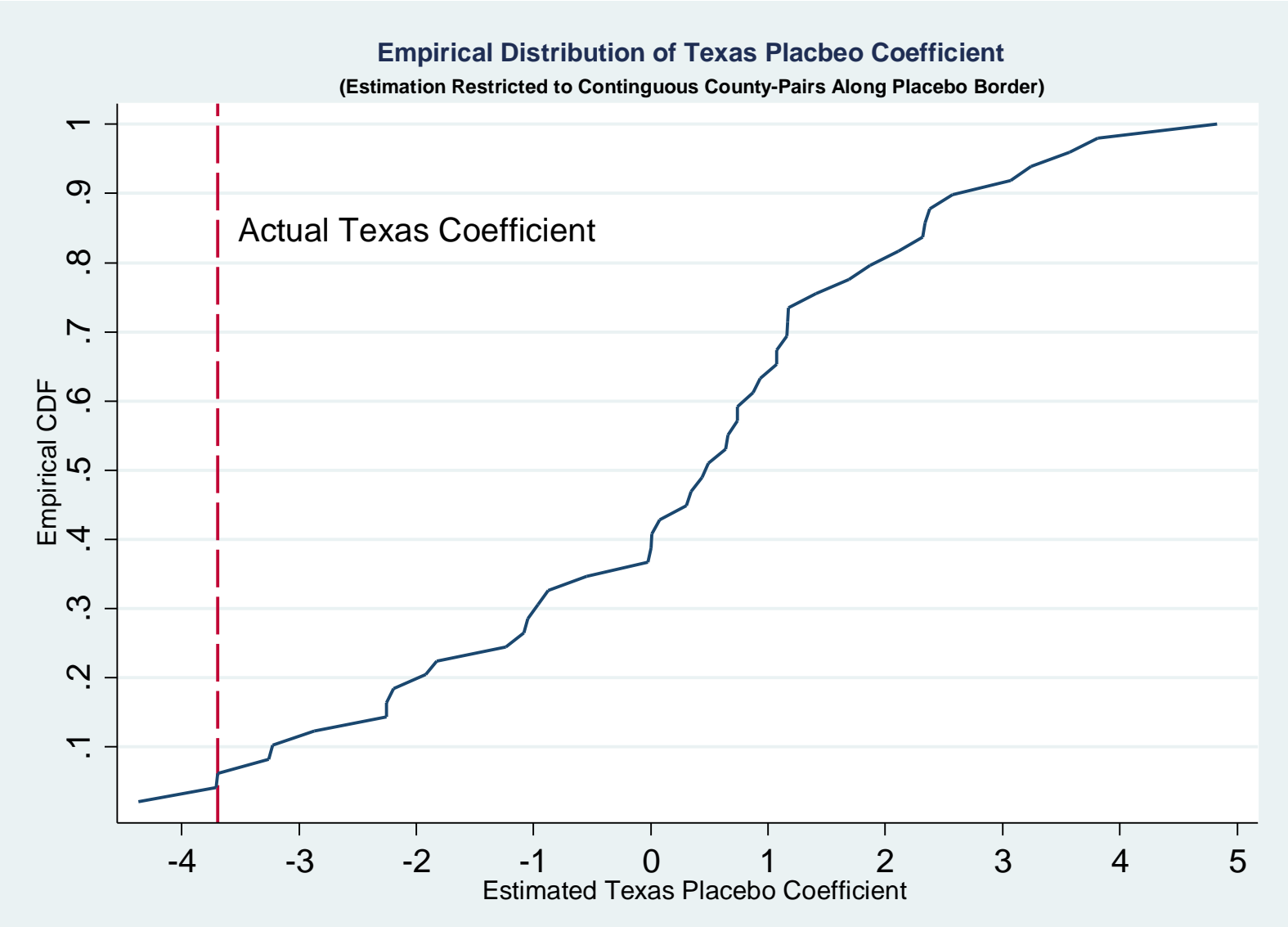

The figure shows the empirical CDF of the 48 placebo estimates using contiguous border county pairs around the borders of the 48 contiguous states. Placebo estimates based on a simple regression of nonprime mortgage default rate on the placebo state dummy and a parsimonious set of key county-level covariates: the unemployment rate, Lagged $\triangle H P I$, initial FICO score, county-pair effects, and year effects. The Texas coefficient is plotted in the chart as a dashed vertical line. The empirical CDF of the Texas coefficient can be interpreted as the p-value for the null hypothesis that the coefficient is zero. 


\section{Figure B2}

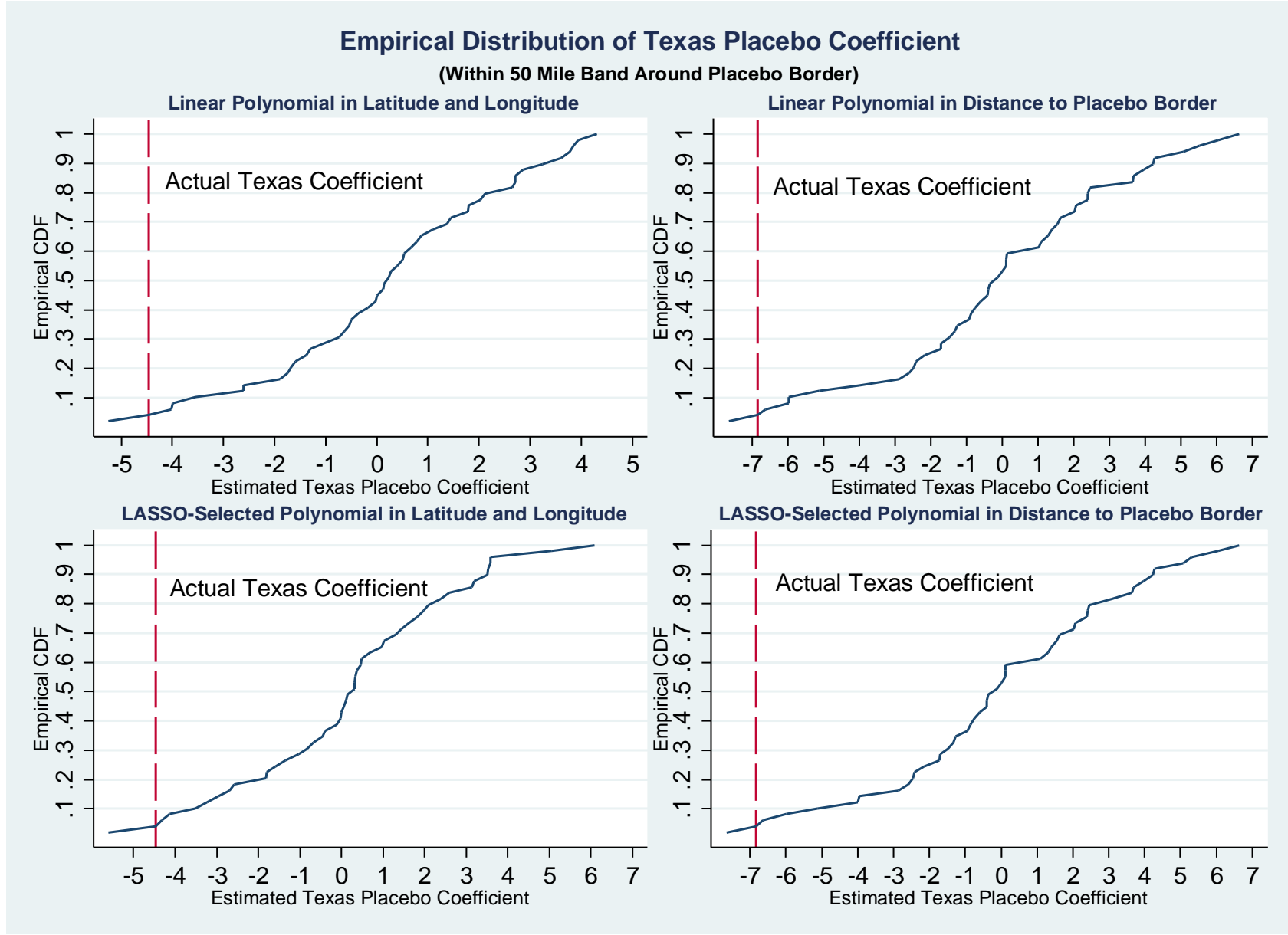

The figure shows the empirical CDF of the 48 placebo estimates using RD estimation based on all counties within 50 miles around the borders of the 48 contiguous states. Placebo estimates are based on a simple regression of nonprime mortgage default rate on the placebo state dummy, the RD polynomial and a parsimonious set of key county-level covariates: the unemployment rate, Lagged $\Delta$ HPI, initial FICO score, and year effects. The Texas coefficient is plotted in the chart as a dashed vertical line. The empirical CDF of the Texas coefficient can be interpreted as the p-value for the null hypothesis that the coefficient is zero. 


\section{Figure B3}

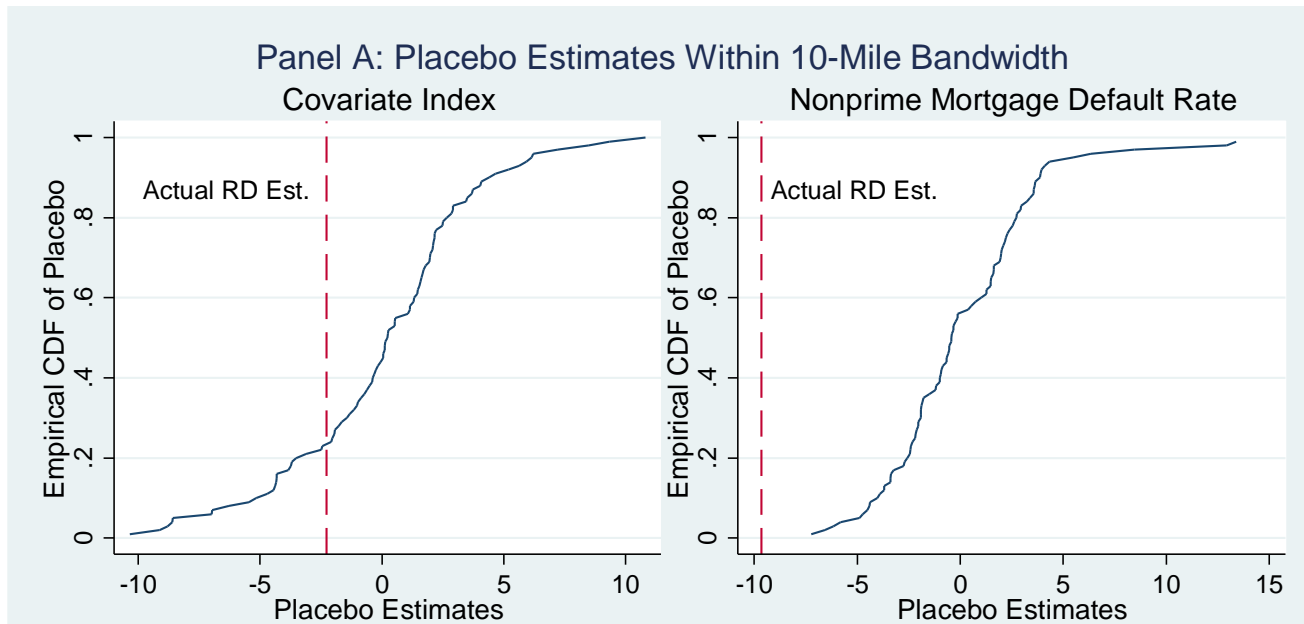

Panel B: Placebo Estimates Within MSE-Optimal 78-Mile Bandwidth
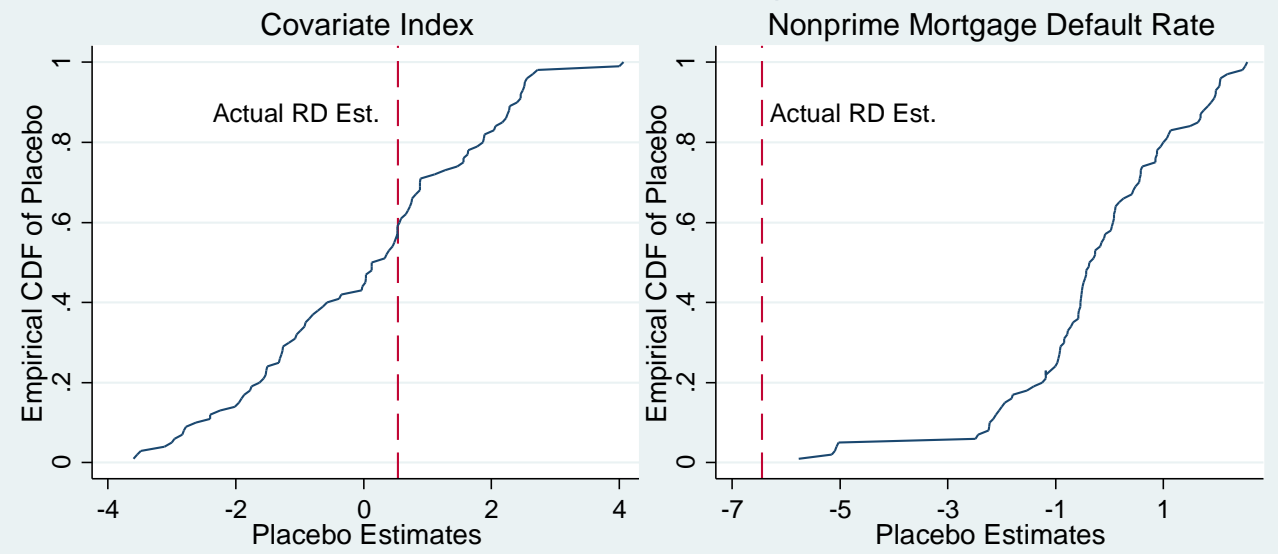

Panel C: Implied P-value on Estimated Discontinuity from Placebo by Bandwidth
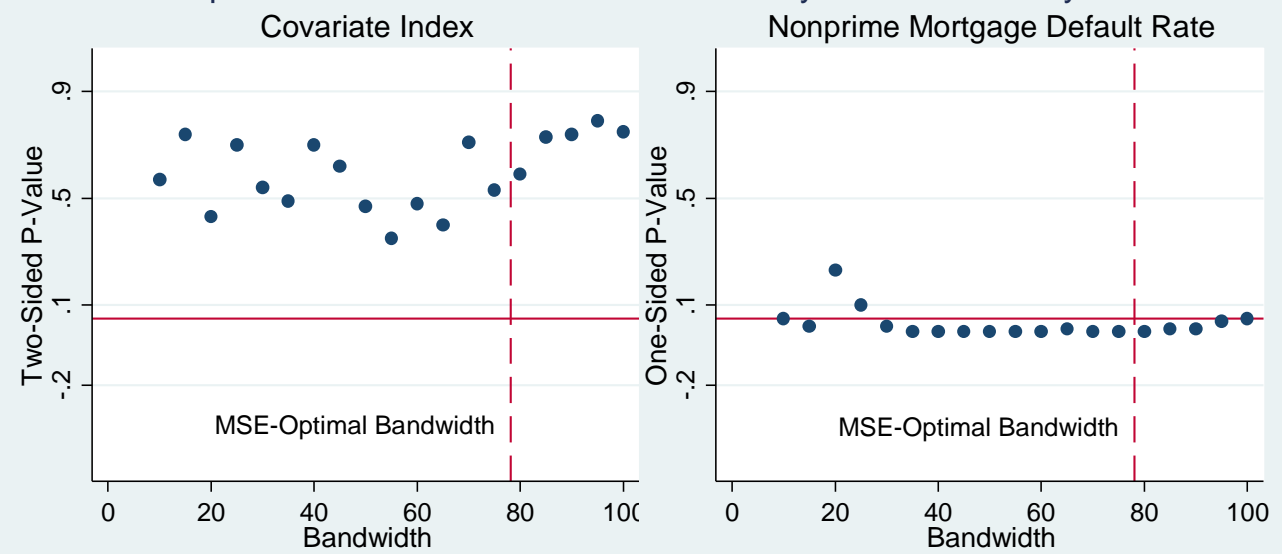

Panel A and B plot the distribution of the estimated discontinuities at 100 randomly drawn placebo cutoffs within the estimation sample and shows how they compare with the estimated discontinuity (denoted by the red dashed line) at the actual cutoff-the Texas border. The implied p-value is calculated as the share of placebo estimates that are at least as extreme as the actual estimate. Panel C presents implied p-values from analogous placebo distributions for bandwidths from 10 miles to 100 miles. A two-sided p-value is reported for the covariate index and a one-sided p-value for the outcome variable. The dashed red vertical line in Panel C denotes the MSE-optimal bandwidth and solid red line denotes the p-value of 0.05 . 


\section{Appendix C: LASSO Specifications}

To minimize bias from potentially omitting terms in the RD polynomial, the first two steps of the post-double-LASSO treatment effect estimator consist of using LASSO to select terms in $\sum_{p=0}^{P} \sum_{q=0}^{Q} \delta_{p q} X_{c S}^{p} Y_{c S}^{q}$ that are sufficiently correlated with the outcome variable mortgage default and the Texas treatment dummy (Texas $)$, respectively. The union of the two sets of terms then replaces the RD polynomial in estimation of (2) and (4) in the third step. More specifically, let $\tilde{y}$ represent the residuals after partialling out all covariates from the dependent variable and the treatment dummy. LASSO uses the following penalized least squares to select the number of terms in the RD polynomial strongly correlated with each of the two variables: ${ }^{27}$

$$
\left(\tilde{y}_{i c s t}-\sum_{p=0}^{P} \sum_{q=0}^{Q} \delta_{p q} X_{c s}^{p} Y_{c s}^{q}\right)^{2}+\frac{\lambda}{n} \sum_{p=0}^{P} \sum_{q=0}^{Q}\left|\delta_{p q}\right| \psi_{p q}
$$

LASSO minimizes least square errors subject to a constraint on the sum of absolute value of coefficients. In equation (5), $\lambda$ is a penalty level determining the parsimony or the number of nonzero coefficients in the model and $\psi_{p q}$ are penalty loadings. A high $\lambda$ selects parsimonious models by setting weakly correlated terms to zero, while a small $\lambda$ yields models with large number of terms. Note that $\lambda=0$ yields the OLS specification. I select both $\lambda$ based on practical guidelines and procedures by Belloni et al. (2014a) who suggest that a particularly good choice is:

$$
\hat{\lambda}=2.2 \sqrt{n} \Phi(1-(.1 / \log (\max (k, n))) /(2 k)),
$$

where $k$ is the number of number of terms in the RD polynomial, $n$ the number of observations, and $\Phi($.$) is the standard normal CDF. I also explore the sensitivity of estimates to different choices$ of $\lambda$.

Tables C1-C3 examine the sensitivity of post-double-LASSO estimates to different LASSO penalty levels $\hat{\lambda}$. The top panel repeats estimates using $\hat{\lambda}$ from Table 3 that was based on equation (6). The middle panel sets the penalty level to half of $\hat{\lambda}$. The number of terms selected in the multidimensional $\mathrm{RD}$ increases slightly for some distance bands, as expected, but estimates remain largely identical. The bottom panel further reduces the penalty level to just $1 / 5^{\text {th }}$ of $\hat{\lambda}$ and shows that although a larger number of terms is selected as the penalty level is lowered, estimated

\footnotetext{
27 (Belloni et al., 2014a) show that other baseline covariates can be straightforwardly included in the final step of the post-double-LASSO treatment effect estimator by partialling them out from the outcome variable and each of the set of regressors on which LASSO selection is being used, before embarking on the first two steps.
} 
impacts are highly robust to changes in LASSO penalty levels. Overall, Table B1 shows that multidimensional RD estimates are not particularly sensitive to chosen penalty levels.

Table C2 is isomorphic to Table C1 and shows that multidimensional RD estimates for nonprime mortgages using post-double-LASSO to select number of terms in the RD polynomial are remarkably robust to different LASSO penalty levels $\hat{\lambda}$. Post-double-LASSO estimates with one-dimensional RD polynomial yielded results similar to baseline linear specifications presented in the bottom panel of Table 2 and are not presented due to space constraints. Finally, Table C3 shows that the post-double-LASSO estimates presented in Table A4 are robust to different LASSO penalty levels $\hat{\lambda}$. 
Table C1: Robustness of Multidimensional RD with Post-Double-LASSO to LASSO Penalty

(Dependent Variable: County-Level Default Rate)

(Data: LPS Data on All Mortgages Grouped to County Level)

\begin{tabular}{|c|c|c|c|c|c|}
\hline $\begin{array}{l}\text { Distance Band } \\
\text { at Texas Border }\end{array}$ & $\begin{array}{c}(1) \\
<25 \\
\text { miles }\end{array}$ & $\begin{array}{c}(2) \\
<50 \\
\text { miles }\end{array}$ & $\begin{array}{c}(3) \\
<75 \\
\text { miles }\end{array}$ & $\begin{array}{c}(4) \\
<100 \\
\text { miles }\end{array}$ & $\begin{array}{l}\text { (5) } \\
\text { All }\end{array}$ \\
\hline \multicolumn{6}{|c|}{ LASSO $\hat{\lambda}=2.2 \sqrt{n} \Phi(1-(.1 / \log (\max (k, n))) /(2 k))^{\S}$} \\
\hline Texas & $\begin{array}{c}-1.678^{* *} \\
(0.447)\end{array}$ & $\begin{array}{c}-1.463^{* *} \\
(0.413)\end{array}$ & $\begin{array}{l}-0.804^{*} \\
(0.429)\end{array}$ & $\begin{array}{l}-0.591^{*} \\
(0.321)\end{array}$ & $\begin{array}{c}-0.700^{* *} \\
(0.207)\end{array}$ \\
\hline $\begin{array}{l}\text { LASSO Selected } \\
\text { Polynomial Terms }\end{array}$ & $X$ & $X$ & None & $X, Y, X Y$ & $X, Y, X Y$ \\
\hline \multicolumn{6}{|c|}{ LASSO $\lambda=\hat{\lambda} / 2^{\S}$} \\
\hline Texas & $\begin{array}{c}-1.532 * * \\
(0.357)\end{array}$ & $\begin{array}{c}-1.401^{* *} \\
(0.379)\end{array}$ & $\begin{array}{c}-1.099 * * \\
(0.394)\end{array}$ & $\begin{array}{c}-0.617^{* *} \\
(0.313) \\
\end{array}$ & $\begin{array}{c}-0.687^{* *} \\
(0.251)\end{array}$ \\
\hline $\begin{array}{l}\text { LASSO Selected } \\
\text { Polynomial Terms }\end{array}$ & $X, Y$ & $X, Y$ & $X, Y, X Y$ & $\begin{array}{c}X, Y, X Y, \\
X Y^{3}\end{array}$ & $\begin{array}{c}X, Y, X Y, \\
X^{2} Y \\
\end{array}$ \\
\hline \multicolumn{6}{|c|}{ LASSO $\lambda=\hat{\lambda} / 5^{\S}$} \\
\hline Texas & $\begin{array}{c}-1.377^{* *} \\
(0.290)\end{array}$ & $\begin{array}{c}-1.576^{* *} \\
(0.373)\end{array}$ & $\begin{array}{c}-1.499^{* *} \\
(0.322)\end{array}$ & $\begin{array}{c}-0.986^{* *} \\
(0.312)\end{array}$ & $\begin{array}{c}-0.687^{* *} \\
(0.251)\end{array}$ \\
\hline $\begin{array}{l}\text { LASSO Selected } \\
\text { Polynomial Terms }\end{array}$ & $\begin{array}{c}X, Y, X^{2} \\
X Y^{2}\end{array}$ & $\begin{array}{c}X, Y, X Y, \\
Y^{4}, X Y^{3}\end{array}$ & $\begin{array}{c}X, Y, X Y, \\
Y^{4}, X Y^{3}\end{array}$ & $\begin{array}{l}X, Y, X Y, \\
Y^{4}, X Y^{3}\end{array}$ & $\begin{array}{c}X, Y, X Y, \\
X^{2} Y\end{array}$ \\
\hline Observations & 310 & 568 & 828 & 1072 & 2250 \\
\hline Counti & 64 & 116 & 169 & 218 & 456 \\
\hline$R$-Square & 0.8765 & 0.8747 & 0.8993 & 0.8853 & 0.8288 \\
\hline Other & Yes & Yes & Yes & Yes & Yes \\
\hline Year Effects & Yes & Yes & Yes & Yes & Yes \\
\hline Border FE & Yes & Yes & Yes & Yes & Yes \\
\hline
\end{tabular}

*Significant at $10 \%$ level; **Significant at 5\% level. Robust standard errors clustered by county in parenthesis. The dependent variable mortgage default is defined as share of mortgages 90-plus days delinquent or in foreclosure or REO. Results presented are from linear regression of countyyear level mortgage default rates from 2007 to 2011 on the Texas dummy and multidimensional $\mathrm{RD}$ polynomial in latitude and longitude. Other county-level baseline covariates included are the county unemployment rate, 1-year lagged log house price change (Lagged $\Delta \mathrm{HPI}$ ), county-level initial FICO score, share of mortgages with initial LTV 80 percent or higher, county-level log median household income, share of adjustable rate mortgages, share of cash-out refinance mortgages, and average county-level mortgage denial rate between 2000 and 2006, year effects, and state border-segment fixed effects. Estimates weighted by number of loans in each countyyear cell. The coefficient on the Texas dummy should be interpreted as the discontinuity in mortgage default rate on Texas side of the border vis-a-vis NM, OK, AR, and LA side of the border. Data from (Holmes, 1998) was used to get distances of county centroid to the Texas border with respective states. Data on county-level nonprime default rates and other mortgage characteristics are from the LPS database on all residential mortgages. ${ }^{\S}$ LASSO penalty level $\lambda$ chosen using guidelines in Belloni et al. (2014a); see equation (6). 
Table C2: Robustness of Multidimensional RD with Post-Double-LASSO to LASSO Penalty

(Dependent Variable: County-Level Default Rate)

(Data: ABS Data on Nonprime Mortgages Grouped to County Level)

\begin{tabular}{|c|c|c|c|c|c|}
\hline $\begin{array}{l}\text { Distance Band } \\
\text { at Texas Border }\end{array}$ & $\begin{array}{c}(1) \\
<25 \\
\text { miles } \\
\end{array}$ & $\begin{array}{c}(2) \\
<50 \\
\text { miles } \\
\end{array}$ & $\begin{array}{c}(3) \\
<75 \\
\text { miles } \\
\end{array}$ & $\begin{array}{c}(4) \\
<100 \\
\text { miles } \\
\end{array}$ & $\begin{array}{l}\text { (5) } \\
\text { All }\end{array}$ \\
\hline \multicolumn{6}{|c|}{ LASSO $\hat{\lambda}=2.2 \sqrt{n} \Phi(1-(.1 / \log (\max (k, n))) /(2 k))^{\S}$} \\
\hline Texas & $\begin{array}{c}-3.581 * * \\
(1.352)\end{array}$ & $\begin{array}{c}-4.019 * * \\
(0.896)\end{array}$ & $\begin{array}{c}-3.609 * * \\
(1.002)\end{array}$ & $\begin{array}{c}-2.128 * * \\
(0.846)\end{array}$ & $\begin{array}{c}-2.905^{* *} \\
(0.746)\end{array}$ \\
\hline $\begin{array}{l}\text { LASSO Selected } \\
\text { Polynomial Terms }\end{array}$ & $Y, Y^{2}$ & None & $X, Y^{2}$ & $X$ & $X, Y, X Y$ \\
\hline \multicolumn{6}{|c|}{ LASSO $\lambda=\hat{\lambda} / 2^{\S}$} \\
\hline Texas & $\begin{array}{c}-3.581^{* *} \\
(1.352)\end{array}$ & $\begin{array}{c}-3.810 * * \\
(0.830)\end{array}$ & $\begin{array}{c}-3.232 * * \\
(0.939)\end{array}$ & $\begin{array}{c}-1.905^{* *} \\
(0.896)\end{array}$ & $\begin{array}{c}-2.905^{* *} \\
(0.746)\end{array}$ \\
\hline $\begin{array}{l}\text { LASSO Selected } \\
\text { Polynomial Terms }\end{array}$ & $Y, Y^{2}$ & $X$ & $X, Y, Y^{2}$ & $X, Y, Y, Y^{3}$ & $X, Y, X Y$ \\
\hline \multicolumn{6}{|c|}{ LASSO $\lambda=\hat{\lambda} / 5^{\S}$} \\
\hline Texas & $\begin{array}{c}-4.420 * * \\
(1.188)\end{array}$ & $\begin{array}{c}-4.072 * * \\
(0.859)\end{array}$ & $\begin{array}{c}-3.629 * * \\
(0.921)\end{array}$ & $\begin{array}{c}-2.117 * * \\
(0.851)\end{array}$ & $\begin{array}{c}-2.905^{* *} \\
(0.746)\end{array}$ \\
\hline $\begin{array}{l}\text { LASSO Selected } \\
\text { Polynomial Terms }\end{array}$ & $X, Y^{2}, X Y^{3}$ & $X, Y^{3}, X^{2} Y^{2}$ & $\begin{array}{c}X, Y, Y^{2}, \\
X Y\end{array}$ & $X, Y, Y^{3}$ & $X, Y, X Y$ \\
\hline Observations & 310 & 569 & 829 & 1073 & 2252 \\
\hline Counties & 64 & 117 & 170 & 219 & 457 \\
\hline R-Square & 0.8977 & 0.8888 & 0.8985 & 0.9115 & 0.8733 \\
\hline Other Covariates & Yes & Yes & Yes & Yes & Yes \\
\hline Year Effects & Yes & Yes & Yes & Yes & Yes \\
\hline Border FE & Yes & Yes & Yes & Yes & Yes \\
\hline
\end{tabular}

*Significant at 10\% level; **Significant at 5\% level. Robust standard errors clustered by county in parenthesis. The dependent variable mortgage default is defined as share of mortgages 90 day+ delinquent or in foreclosure or REO. Results presented are from linear regression of county-year level mortgage default rates from 2007 to 2011 on the Texas dummy and multidimensional RD polynomial in latitude and longitude. Other county-level baseline covariates included are the county unemployment rate, 1-year lagged log house price change (Lagged $\Delta$ HPI), county-level initial FICO score, share of mortgages with initial CLTV 80 percent or higher, county-level log median household income, share of adjustable rate mortgages, share of cash-out refinance mortgages, and average county-level mortgage denial rate between 2000 and 2006, year effects, and state border-segment fixed effects. Estimates weighted by number of loans in each countyyear cell. The coefficient on the Texas dummy should be interpreted as the discontinuity in mortgage default rate on Texas side of the border vis-a-vis NM, OK, AR, and LA side of the border. Data from (Holmes, 1998) was used to get distances of county centroid to the Texas border with respective states. Data on county-level nonprime default rates and other mortgage characteristics are from ABS database on nonprime mortgages. ${ }^{\S}$ LASSO penalty level $\lambda$ chosen using guidelines in (Belloni et al., 2014a); see equation (6). 
Table C3: Robustness to Inclusion of State-Level Policy Variables using Multidimensional RD with Post-Double-LASSO

(Dependent Variable: County-Level Default Rate)

(Data: ABS Data on Nonprime Mortgages Grouped to County Level)

\begin{tabular}{|c|c|c|c|c|c|}
\hline $\begin{array}{l}\text { Distance Band } \\
\text { at Texas Border }\end{array}$ & $\begin{array}{c}(1) \\
<25 \\
\text { miles }\end{array}$ & $\begin{array}{c}(2) \\
<50 \\
\text { miles }\end{array}$ & $\begin{array}{c}(3) \\
<75 \\
\text { miles }\end{array}$ & $\begin{array}{c}(4) \\
<100 \\
\text { miles }\end{array}$ & $\begin{array}{l}\text { (5) } \\
\text { All }\end{array}$ \\
\hline \multicolumn{6}{|c|}{ LASSO $\hat{\lambda}=2.2 \sqrt{n} \Phi(1-(.1 / \log (\max (k, n))) /(2 k))^{\S}$} \\
\hline Texas & $\begin{array}{c}-6.465 * * \\
(2.003)\end{array}$ & $\begin{array}{c}-4.806^{* *} \\
(1.499)\end{array}$ & $\begin{array}{c}-3.878^{* *} \\
(1.593)\end{array}$ & $\begin{array}{l}-2.476^{*} \\
(1.331)\end{array}$ & $\begin{array}{c}-3.087^{* *} \\
(1.249)\end{array}$ \\
\hline $\begin{array}{l}\text { LASSO Selected } \\
\text { Polynomial Terms }\end{array}$ & None & None & None & None & $X, Y$ \\
\hline \multicolumn{6}{|c|}{ LASSO $\lambda=\hat{\lambda} / 2^{\S}$} \\
\hline Texas & $\begin{array}{c}-6.465^{* *} \\
(2.003)\end{array}$ & $\begin{array}{c}-4.806^{* *} \\
(1.499)\end{array}$ & $\begin{array}{c}-3.486^{* *} \\
(1.743)\end{array}$ & $\begin{array}{c}-3.308^{* *} \\
(1.332)\end{array}$ & $\begin{array}{c}-3.288^{* *} \\
(1.300)\end{array}$ \\
\hline $\begin{array}{l}\text { LASSO Selected } \\
\text { Polynomial Terms }\end{array}$ & None & None & $X, Y^{2}$ & $X, X^{2}$ & $X, Y, X^{2}$ \\
\hline \multicolumn{6}{|c|}{ LASSO $\lambda=\hat{\lambda} / 5^{\S}$} \\
\hline Texas & $\begin{array}{c}-6.986 * * \\
(2.081)\end{array}$ & $\begin{array}{c}-5.282^{* *} \\
(1.639)\end{array}$ & $\begin{array}{c}-3.322^{*} \\
(1.692)\end{array}$ & $\begin{array}{c}-2.986^{* *} \\
(1.384)\end{array}$ & $\begin{array}{c}-4.556^{* *} \\
(1.516)\end{array}$ \\
\hline $\begin{array}{l}\text { LASSO Selected } \\
\text { Polynomial Terms }\end{array}$ & $X$ & $\begin{array}{c}X, X^{2}, X Y, \\
Y^{4} \\
\end{array}$ & $\begin{array}{c}X, Y, X^{2}, \\
Y^{2}, Y^{4}\end{array}$ & $\begin{array}{c}X, Y, X^{2}, \\
Y^{2}, Y^{4}\end{array}$ & $\begin{array}{c}X, Y, X^{2}, Y^{2}, X Y, \\
X^{2} Y\end{array}$ \\
\hline Observations & 310 & 569 & 829 & 1073 & 2252 \\
\hline Counties & 64 & 117 & 170 & 219 & 457 \\
\hline$R$-Square & 0.9042 & 0.8980 & 0.9074 & 0.9160 & 0.8751 \\
\hline Other Covariates & Yes & Yes & Yes & Yes & Yes \\
\hline State Policy Vars & Yes & Yes & Yes & Yes & Yes \\
\hline Year Effects & Yes & Yes & Yes & Yes & Yes \\
\hline Border FE & Yes & Yes & Yes & Yes & Yes \\
\hline
\end{tabular}

*Significant at $10 \%$ level; **Significant at $5 \%$ level. Robust standard errors clustered by county in parenthesis. The dependent variable mortgage default is defined as share of mortgages 90 day+ delinquent or in foreclosure or REO. Results presented are from linear regression of county-year level mortgage default rates from 2007 to 2011 on the Texas dummy and multidimensional RD polynomial in latitude and longitude. Other county-level baseline covariates included are the county unemployment rate, 1-year lagged log house price change (Lagged $\Delta \mathrm{HPI}$ ), county-level initial FICO score, share of mortgages with initial CLTV 80 percent or higher, county-level log median household income, share of adjustable rate mortgages, share of cash-out refinance mortgages, average county-level mortgage denial rate between 2000 and 2006, year effects, and state border-segment fixed effects. Estimates are weighted by number of loans in each countyyear cell. The coefficient on the Texas dummy should be interpreted as the discontinuity in mortgage default rate on Texas side of the border vis-a-vis NM, OK, AR, and LA side of the border. Data from (Holmes, 1998) was used to get distances of county centroid to the Texas border with respective states. Data on county-level nonprime default rates and other mortgage characteristics are from ABS database on nonprime mortgages. State-specific policy variables included are dummies for judicial foreclosure, whether the state allows redemption, and state-level house price elasticity. ${ }^{\S}$ LASSO penalty level $\lambda$ chosen using guidelines in Belloni et al. (2014a); see equation (6). 